\title{
BRUNA BACALGINI
}

O serviço de disponibilização de e-books pelas bibliotecas universitárias: análise do ponto de vista da gestão de operações de serviços

São Paulo 
BRUNA BACALGINI

O serviço de disponibilização de e-books pelas bibliotecas universitárias: análise do ponto de vista da gestão de operações de serviços

Dissertação apresentada à Escola Politécnica da Universidade de São Paulo para obtenção do título de Mestre em Ciência

São Paulo

2016 
BRUNA BACALGINI

O serviço de disponibilização de e-books pelas bibliotecas universitárias: análise do ponto de vista da gestão de operações de serviços

Dissertação submetida ao Programa de Pós-Graduação em Engenharia de Produção para obtenção do título de Mestre em Ciências.

Área de Concentração: Engenharia de Produção

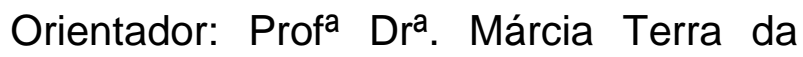
Silva.

São Paulo

2016 
Este exemplar foi revisado e corrigido $\mathrm{cm}$ relaçao à versaao original, sob responsabilidade única do autor c com a anuencia de seu orientador.
Sáo Paulo, 7 de Abril de 20.56
Assinatura do autor: Buwna Bacaloxini
Assinatura do orientador: Anacicia Sina da Litora

Bacalgini, Bruna

O serviço de disponibilizaçào de e-books pelas bibliotecas universitárias: análise do ponto de vista da gestảo de operaçōes de serviços / B. Bacalgini -versäo corr. -- Sào Paulo, 2016

$147 \mathrm{p}$.

Dissertaçào (Mestrado) - Escola Politécnica da Universidade de São Paulo. Departamento de Engenharia de Produçảo.

1.Livros eletrónicos 2.Administração 3. Biblioteca universitária I.Universidade de Sao Paulo. Escola Politécnica. Departamento de Engenharia de Produçào Il.t. 


\section{AGRADECIMENTOS}

À Deus pela vida, à Jesus pela esperança de Sua volta e ao Espírito Santo pela guia.

Aos meus pais pelo apoio e amor incondicional.

À Prof ${ }^{a}$ Dr ${ }^{a}$ Márcia Terra da Silva pela incrível paciência e compreensão desde o início, assim como pela orientação e críticas.

Aos professores Prof. Dr. Jorge Muniz Júnior e Prof. Dr. José Fernando Modesto da Silva pela participação na banca e valiosas contribuições na qualificação.

À Adaci e à Amanda, que me dão muito amor e me ajudam a superar as dificuldades e a sorrir.

À Grazi pela amizade genuína e pelas referências.

Ao Beto e à Iramaia pelas sugestões à pesquisa e pela torcida.

À Ligia pelo apoio de sempre e pelas referências.

Ao Alex pelas traduções e pela amizade.

A toda a minha família pela torcida e amor constante.

Ao Clube de Jovens Raridades da IASD e aos meus amigos da Missão Calebe, a amizade de vocês foi e é importantíssima em terras sorocabanas.

Aos meus amigos de Lagoa Salgada e Sobrado - Rio Grande do Norte, vocês renovam minhas forças e ânimo.

Aos professores do Departamento da Engenharia de Produção da POLI-USP pelos ensinamentos.

Aos meus amigos da Unesp Sorocaba: todos os funcionários que me apoiaram para continuar meus estudos e em especial aos meus colegas diários de trabalho: Luci, Janete e Marcos Malaquias, os quais sempre foram gentis, alegres e esforçados. Agradeço também ao Marcos Dionízio, o qual com seus conselhos e estilo de trabalho me ajudou a crescer como profissional e líder.

Aos diretores de biblioteca, bibliotecários e assistentes de biblioteca da Unesp e USP pela qualidade do serviço prestado, o qual foi fundamental para a construção desta dissertação. Agradeço em especial a Coordenadoria Geral de Bibliotecas da Unesp pelo apoio no fornecimento de dados e por sempre estar aberta a compartilhar ideias.

À Universidade de São Paulo, pela minha formação desde a graduação e por toda a infraestrutura disponível para seus alunos em termos acadêmicos, científicos, administrativos, culturais, de saúde e esportivos.

À Universidade Estadual Paulista pela oportunidade profissional. 
"Quando pensarmos em livros, pensemos, em primeiro lugar, nas sociedades. Quando estivermos inquietos com o futuro dos livros, consideremos, antes de tudo, com maior atenção a sociedade e suas tendências. Para tornarmos os livros mais adaptados à sociedade em que vivemos, estejamos vigilantes para evitar que a sociedade se torne inadaptada aos livros" Zygmunt Bauman.

"E, demais disto, filho meu, atenta: não há limite para fazer livros..." Eclesiastes 12:12 


\section{RESUMO}

As bibliotecas universitárias brasileiras procuram oferecer 0 acesso de livros eletrônicos (e-books) aos usuários, contudo, o uso de e-books está aquém do esperado em bibliotecas, esta situação nos leva ao problema de pesquisa: haveria problemas na produção do serviço de disponibilização de e-books na biblioteca universitária que afetem o uso de e-books nas bibliotecas? Que tipos de problemas podem estar relacionados? Esta pesquisa tem como objetivo analisar a gestão de ebooks em bibliotecas universitárias, com o propósito de compreender melhor o uso de e-books na biblioteca e detectar possíveis problemas na produção do serviço. A partir de um estudo de caso de uma rede de bibliotecas de uma universidade pública brasileira e de revisão de literatura, constatou-se que há quatro principais tipos de problemas na gestão de e-books: comerciais, institucionais, organizacionais e conceituais, os quais estão diretamente relacionados com o baixo uso de e-books nas bibliotecas universitárias. A base teórica em gestão de serviços permitiu identificar a relação entre a necessidade de revisão do conceito de serviço de biblioteca acadêmica em conjunto com a solução de questões pontuais de gestão, avançando no entendimento do problema.

Palavras-chave: Livros eletrônicos. Administração. Biblioteca universitária. 


\begin{abstract}
Academic brazilian libraries seek to provide access to electronic books (e-books), however, the use of e-books are less than expected in libraries, which brings us to the research problem: there would be problems in the production of service of availability of e-books in the academic library that affect the use of e-books in libraries? What types of problems may be related? This research aims to analyze the management of e-books in academic libraries, in order to better understand the use of e-books in the library and identify potential problems in the production of the service. From a case study of academic libraries of a public brazilian university and literature review, it was found that there are four main types of problems in e-book management: commercial, institutional, organizational and conceptual, which are directly related to the low use of e-books in academic libraries. The theoretical basis of management services identified the relationship between the need to revise the concept of academic library service together with the solution of specific management issues, advancing the understanding of the problem.
\end{abstract}

Keywords: Electronic books. Management. Academic library. 


\section{LISTA DE FIGURAS}

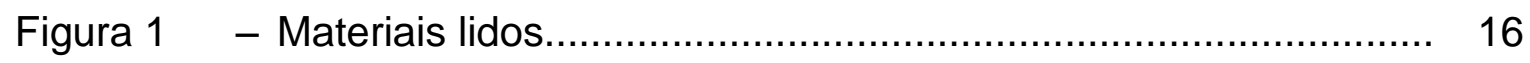

Figura 2 - Perfil do leitor de livros eletrônicos no Brasil............................. 17

Figura 3 - Elementos tecnológicos constituintes do livro eletrônico........... 23

Figura $4 \quad$ - E-reader Rocket e-book......................................... 24

Figura 5 - MEMEX................................................................ 25

Figura 6 - Cadeia produtiva do livro impresso........................................ 28

Figura 7 - Rede de produção do livro eletrônico....................................... 33

Figura 8 - Sistema de produção para o ensino de graduação................... 41

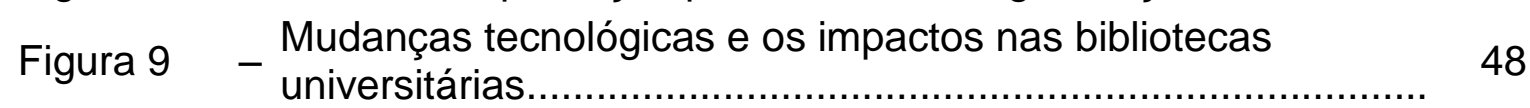

Figura 10 - Modelo tradicional de comunicação e produção científica........ 49

Figura 11 - Conceito de serviço de Johnston e Clark (2002)..................... 56

Figura 12 - Modelo de gestão de e-books de Vasileiou, Rowley e Hartley 59

Figura 13 - Estrutura organizacional................................................... 66

Figura 14 - Gestão de e-books na Unesp em modelo service blueprinting.. 118 


\section{LISTA DE TABELAS}

Tabela 1 - Faturamento total do mercado norte-americano........................ 13

Tabela 2 - Faturamento total do mercado norte-americano por setor......... 13

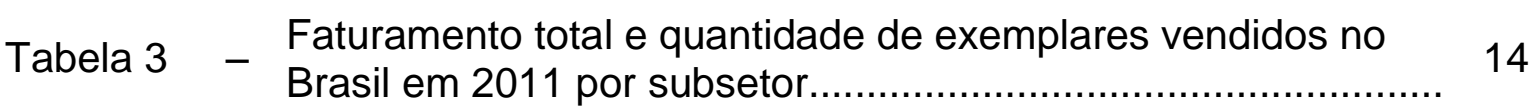

Tabela 4 - Faturamento total e quantidade de exemplares vendidos no $\quad 15$

Tabela 5 - Faturamento total e quantidade de títulos de livros eletrônicos $\quad 15$ 


\section{LISTA DE QUADROS}

Quadro 1 - Modelo PESTEL para e-books............................................. 38

Quadro 2 - Tratamento da informação................................................... 43

Quadro 3 - Referência.............................................................. 44

Quadro 4 - Conceito de serviço de biblioteca universitária: difusora versus 57 produtora de informação.

Quadro 5 - Aplicação da metodologia de Perkmann et al. (2013)................ 62

Quadro 6 - Atividades desempenhadas pelas bibliotecas da Unesp........... 67

Quadro 7 - Roteiro para entrevistas semiestruturadas.............................. 69

Quadro 8 - Principais problemas nas etapas de gestão de e-books apontados na entrevista com a CGB.................................... 80

Quadro 9 - Principais problemas nas etapas de gestão de e-books apontados nas entrevistas com os diretores de biblioteca......... 91

Quadro 10 - Principais problemas na gestão de e-books.............................. 122 


\section{SUMÁRIO}

1. INTRODUÇÃO................................................................. 12

2. REFERENCIAL TEÓRICO............................................... 22

2.1. Livro eletrônico.................................................................. 22

2.1.1. Definição............................................................. 22

2.1.2. Histórico.................................................................... 24

2.1.3. Atores envolvidos....................................................... 26

2.2. As atividades dos usuários................................................ 39

2.3. A biblioteca universitária.................................................. 41

2.3.1. Mudanças nas bibliotecas universitárias com as tecnologias. 47

2.3.2. As bibliotecas como produtoras de serviços e provedoras de 53 conteúdo.

3. PROCEDIMENTOS METODOLÓGICOS............................... 61

3.1 Apresentação......................................................................... 61

3.2 Estudo de caso.................................................................... 64

3.3 Entrevistas....................................................................... 68

4. RESULTADOS: Dados coletados........................................ 76

4.1 Entrevistados: CGB - etapas de aquisição e armazenamento..................................................................... 76

$4.2 \quad$ Entrevistados: diretores de biblioteca................................ 81

5. DISCUSSÃO..................................................................... 95

5.1 Questões externas.............................................................. 95

5.2 Questões organizacionais.................................................... 99

5.2.1 Gestão de pessoas, capacitação e divulgação....................... 99

5.2.2 Estrutura organizacional.............................................. 105

5.3 Questões conceituais............................................................. 109

5.4 Gestão de e-books............................................................... 116

6. CONSIDERAÇÕES FINAIS................................................... 121

REFERÊNCIAS.................................................................... 124

GLOSSÁRIO................................................................... 133

APÊNDICE A....................................................................... 135 


\section{INTRODUÇÃO}

O livro eletrônico (electronic book, ou e-book) surgiu nos anos 1970 e somente a partir dos anos 2000 a sua comercialização começou a despontar, mas ainda é um mercado que procura consolidação. As inovações tecnológicas desse formato trazem diversos benefícios e vantagens aos leitores, contudo, alguns modelos de negócio existentes nesse mercado criam obstáculos e dificuldades a bibliotecas, leitores e autores (HERTHER, 2005; PROCÓPIO, 2010).

Os agentes envolvidos na temática do livro eletrônico desenham o cenário para que esta tecnologia tenha suporte desde sua produção até o uso pelos leitores, formando uma rede de produção em que os agentes se relacionam direta ou indiretamente para que o e-book alcance seus leitores seja por meio de livrarias, sites ou bibliotecas; são eles: autores, editoras, fornecedores de e-books (agregadores, distribuidores, livrarias, lojas virtuais) produtores de tecnologia, bibliotecas e entidades ligadas a educação/pesquisa e leitores. Esta rede de produção será explorada nesta pesquisa, sendo destacada na figura 7 .

Observa-se a expansão crescente do e-book no mercado editorial brasileiro e internacional. No Brasil, em 2011, aproximadamente $0,02 \%{ }^{1}$ do faturamento das editoras foi com a venda de livros eletrônicos, sendo que do total de livros lançados, 9\% eram eletrônicos (ANL, 2012; CBL, 2012). De 2011 a 2012, segundo dados da Câmara Brasileira do Livro (CLB), o faturamento correspondeu a $1 \%$ do total (AGÊNCIA BRASIL, 2013), a projeção é que em 2013 tenha crescido para 2,5\%, segundo a consultoria alemã Rüdiger Wischenbart (2014).

Nos Estados Unidos, segundo dados da Association of American Publishers (AAP) de 2010 a 2011 houve um salto nas vendas de livros eletrônicos de US\$ 869 milhões para US\$ 2.07 bilhões, alcançando $15,5 \%$ do total de vendas. Já a venda de livros impressos teve uma queda: de US $\$ 12.1$ bilhões em 2010 para US\$ 11.1 bilhões em $2011^{2}$. Em relação ao faturamento total de e-books de 2011 a 2013 , podemos observar que o setor de livros para adultos (ficção e não ficção) é o que corresponde à maior fatia, conforme as tabelas 1 e 2 :

\footnotetext{
${ }^{1}$ Em 2011, o faturamento total de livros foi de mais de $\mathrm{R} \$ 4$ bilhões, sendo $\mathrm{R} \$ 870$ mil de e-books (aproximadamente 0,02\%), com 5.200 títulos de livros eletrônicos lançados.

2 Dados veiculados no The New York Times, no artigo de 19 de Julho de 2012, disponível em: <http://query.nytimes.com/gst/fullpage.html?res=9F05E6D81E3FF93AA25754C0A9649D8B63>.

Acesso em: 01 fev. 2013.
} 
Tabela 1 - Faturamento total do mercado norte-americano

\begin{tabular}{l|c|c|c}
\hline Faturamento* & $\mathbf{2 0 1 1}$ & $\mathbf{2 0 1 2}$ & $\mathbf{2 0 1 3}$ \\
\hline Total & $\$ 6.691,2$ & $\$ 7.076,9$ & $\$ 7.013,3$ \\
E-books & $\$ 1.092,4$ & $\$ 1.543,5$ & $\$ 1.535$ \\
& & & \\
$\begin{array}{l}\% \text { do faturamento } \\
\text { total }\end{array}$ & $16,3 \%$ & $21,8 \%$ & $21,9 \%$ \\
\hline \multicolumn{3}{|c}{ *Valores em milhões. Porcentagens arredondadas. } \\
Fonte: Dados de 2014 da AAP, retirados do site The Digital Reader ${ }^{3}$.
\end{tabular}

Tabela 2 - Faturamento total do mercado norte-americano por setor

\begin{tabular}{c|c|c|c|c|c|c}
\hline Setor* & $\mathbf{2 0 1 1}$ & $\begin{array}{c}\% \\
\text { e-books }\end{array}$ & $\mathbf{2 0 1 2}$ & $\begin{array}{c}\% \\
\text { e-books }\end{array}$ & $\mathbf{2 0 1 3}$ & $\begin{array}{c}\% \\
\text { e-books }\end{array}$ \\
\hline $\begin{array}{c}\text { Adulto } \\
\text { (Ficção e } \\
\text { não ficção) } \\
\text { Infantil/ }\end{array}$ & $\$ 4.599,2$ & $20 \%$ & $\$ 4.843,2$ & $26 \%$ & $\$ 4.879,7$ & $27 \%$ \\
$\begin{array}{c}\text { Jovens } \\
\text { adultos } \\
\text { Religioso }\end{array}$ & $\$ 1.482,8$ & $7 \%$ & $\$ 1.672,1$ & $14 \%$ & $\$ 1.561,6$ & $11 \%$ \\
\hline
\end{tabular}

${ }^{*}$ Valores em milhões. Porcentagens arredondadas.

Fonte: Dados de 2014 da AAP, retirados do site The Digital Reader ${ }^{4}$.

$\mathrm{Na}$ Europa, o e-book apresenta porcentagens de participação no mercado editorial (market share) maiores no Reino Unido, com 25\% do total. Em geral, a publicação e venda de e-books é maior em países anglófonos. Contudo, há destaque também para a Alemanha com 10\% do market share, Espanha com 3 a 5\% e Países Baixos com 4,7\%, no período de 2011 a 2013 (RÜDIGER WISCHENBART, 2014).

Um país em destaque no setor de e-books é a China, um dos maiores mercados de e-commerce do mundo. Com uma base de 1.1 bilhão de usuários de telefonia celular, caracteriza-se pela intensa disseminação da tecnologia móvel, alguns a nomeiam como "China Mobile". Em 2011, todas as publicações digitais,

3 Disponível em: <http://www.the-digital-reader.com/2014/04/01/new-aap-stats-show-that-the-us-ebook-market-saw-excellent-growth-in-2013/\#.U4lurfldX-u>. Acesso em: 04 maio. 2014.

4 Disponível em: <http://www.the-digital-reader.com/2014/04/01/new-aap-stats-show-that-the-us-ebook-market-saw-excellent-growth-in-2013/\#.U4lurfldX-u>. Acesso em: 04 maio. 2014. 
incluindo e-books somavam $31 \%$ do total da receita do mercado. (RÜDIGER WISCHENBART, 2014).

Voltando ao mercado editorial brasileiro, este é setorizado em quatro: didáticos (títulos para o Ensino Fundamental e Médio), religiosos, CTP (Científicos, Técnicos e Profissionais) e obras gerais (ficção e não ficção), sendo que o subsetor que mais vende títulos é o de didáticos, como indica a tabela 3.

Tabela 3 - Faturamento total e quantidade de exemplares vendidos no Brasil em 2011 por subsetor

\begin{tabular}{c|c|c}
\hline Subsetor & Faturamento & $\%$ \\
\hline Didáticos & $\mathrm{R} \$ 2.383 .749 .066,43$ & $49 \%$ \\
$\begin{array}{c}\text { Obras } \\
\text { Gerais } \\
\text { Religiosos }\end{array}$ & $\mathrm{R} \$ 1.059 .876 .260,39$ & $22 \%$ \\
CTP & $\mathrm{R} \$ 483.749 .629,05$ & $10 \%$ \\
TOTAL & \multicolumn{2}{|c}{$4.837 .439 .173,32$} \\
\hline
\end{tabular}

Fonte: Adaptado de CBL (2012).

A maior parte do faturamento das editoras provém do governo brasileiro, conforme mostra a tabela 4, com seu programa de aquisição de livros: o Programa Nacional do Livro Didático (PNLD). Para 2015, o programa previa a compra de obras digitais, além dos impressos e materiais audiovisuais ${ }^{5}$ Em 2012, o governo adquiriu tablets para uso dos professores do Ensino Médio de escolas públicas ${ }^{6}$.

\footnotetext{
${ }^{5}$ Dados veiculados no jornal O Estado de São Paulo, no artigo de 21 de abril de 2014. Disponível em: $<$ http://www.estadao.com.br/noticias/arte-e-lazer,crescimento-na-venda-de-e-books-no-brasil-devecontinuar-diz-especialista, 1156757,0.htm>. Acesso em: 30 abr. 2014.

${ }^{6}$ Dados veiculados na Revista Info Exame, no artigo de 18 de março de 2014. Disponível em: $<$ http://info.abril.com.br/noticias/tecnologia-pessoal/2014/03/amazon-doa-tecnologia-de-e-books-aomec.shtml>. Acesso em: 04 maio. 2014.
} 
Tabela 4 - Faturamento total e quantidade de exemplares vendidos no Brasil em 2011

\begin{tabular}{c|l|c}
\hline Subsetor & Faturamento R\$ & $\begin{array}{c}\text { Exemplares } \\
\text { vendidos }\end{array}$ \\
\hline Mercado & $3.449 .255 .680,52$ & 283.984 .382 \\
Governo & $1.388 .183 .492,80$ & 185.484 .459 \\
Total & $4.837 .439 .173,32$ & 469.468 .841 \\
\hline \multicolumn{2}{c}{ Fonte: Adaptado de CBL (2012). }
\end{tabular}

O governo brasileiro participa da aquisição de publicações digitais voltadas ao público acadêmico, com a assinatura de cerca de 31 mil periódicos científicos e 150 mil e-books por meio da CAPES (Coordenação de Aperfeiçoamento de Pessoal de Nível Superior), órgão federal ligado ao Ministério da Educação, demonstrando uma vontade governamental e política para a expansão dos e-books na área acadêmica.

A venda de livros eletrônicos no subsetor de didáticos não se destaca. O maior expoente é o de obras gerais, e em segundo lugar, livros CTP, o qual engloba obras de interesse da comunidade acadêmica e científica, como pode ser visto na tabela 5:

Tabela 5 - Faturamento total e quantidade de títulos de livros eletrônicos vendidos no Brasil em 2011 por subsetor

\begin{tabular}{|c|c|c|c|}
\hline \multirow[t]{2}{*}{ Subsetor } & \multirow{2}{*}{$\begin{array}{l}\text { Títulos } \\
\text { Vendidos }\end{array}$} & \multicolumn{2}{|c|}{ Faturamento } \\
\hline & & $\mathbf{R} \$$ & $\%$ \\
\hline $\begin{array}{l}\text { Obras } \\
\text { Gerais }\end{array}$ & 4.131 & $399.483,49$ & $46 \%$ \\
\hline CTP & 856 & $319.459,19$ & $37 \%$ \\
\hline Didáticos & 4 & $114.959,04$ & $13 \%$ \\
\hline Religiosos & 244 & $34.571,00$ & $4 \%$ \\
\hline Total & 5.235 & \multicolumn{2}{|c|}{$868.472,73$} \\
\hline
\end{tabular}

Apesar da expansão do livro eletrônico no mercado, este ainda não é um dos tipos de suportes de leitura favoritos, como revela a pesquisa "Retratos da Leitura no Brasil", que analisa a situação da leitura no Brasil e o comportamento do leitor 
brasileiro, neste sentido, utilizaremos alguns dados para verificar o uso do e-book. $\mathrm{O}$ Instituto Pró-Livro com apoio da ABRELIVROS (Associação Brasileira de Livros Escolares), CBL (Câmara Brasileira de Livros) e SNEL (Sindicato Nacional dos Editores de Livros) empreendem essa pesquisa, a qual se encontra na sua terceira edição aplicada em 2011 e lançada em 2012.

Segundo a pesquisa, o livro eletrônico não é um dos materiais mais lidos, ficando com $4 \%$ do total de entrevistados, conforme exposto na Figura 1:

Figura 1 - Materiais lidos

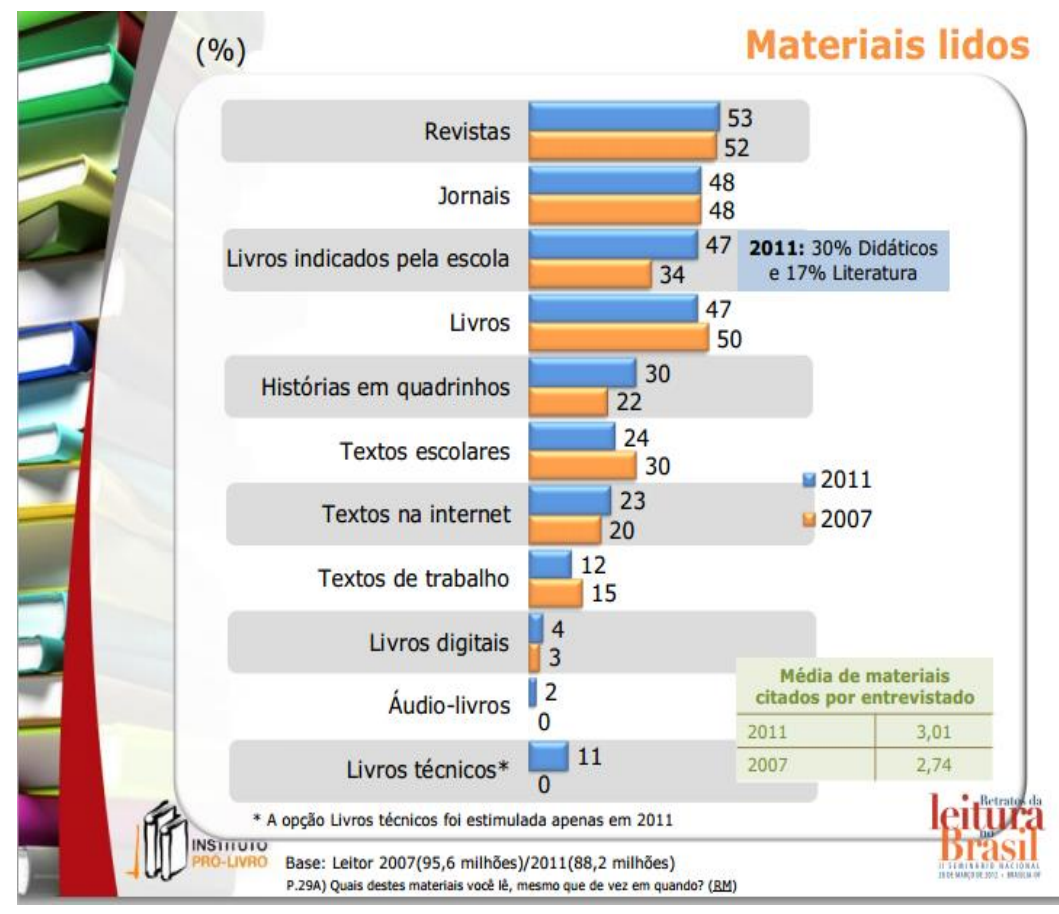

Fonte: Instituto Pró-Livro (2012).

A pesquisa constatou que $45 \%$ dos brasileiros entrevistados nunca tinham ouvido falar de livros eletrônicos; $25 \%$ nunca ouviram falar, mas gostariam de conhecer; e dos $30 \%$ que já ouviram falar, $17 \%$ leram no computador, $1 \%$ no celular e $82 \%$ nunca leram este tipo de formato. Dos que já tiveram contato com o livro eletrônico, 13\% pagaram pelo título e $87 \%$ realizaram download gratuito pela internet; desses $87 \%$, 32\% afirmaram que a origem do arquivo era pirata.

$\mathrm{Na}$ figura 2, podemos observar o perfil do leitor de livros eletrônicos, que tem sua maioria composta por jovens adultos com nível superior de escolaridade: 
Figura 2 - Perfil do leitor de livros eletrônicos no Brasil

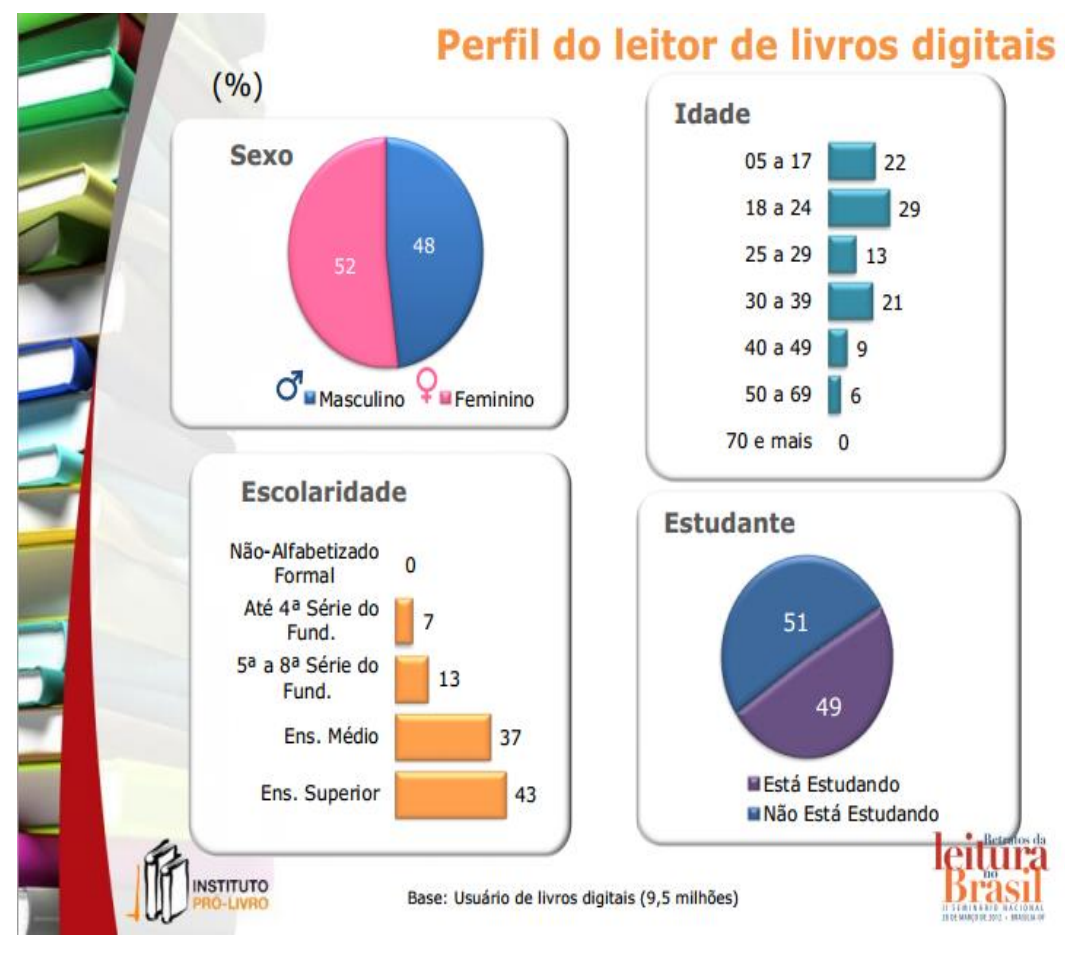

Fonte: Instituto Pró-Livro (2012).

Percebe-se que a consolidação do livro eletrônico no gosto do público leitor e no seu cotidiano é algo ainda a ser desenvolvido. Um dos desafios para a adoção de e-books é superar este hábito culturalmente construído.

O livro em formato digital por vezes é discutido sem a objetividade necessária para analisar as inovações tecnológicas e seus impactos (PINSKY, D., 2009). Ao se estudar o livro eletrônico é necessário cautela para não se adotar partidarismos ou visões "apocalípticas" sobre o futuro do livro impresso; o que se tem em questão é mais do que o suporte, é a própria leitura: como compramos, acessamos, lemos e circulamos livros.

A partir dos dados estatísticos apresentados, percebe-se no Brasil um potencial de crescimento dos livros eletrônicos nas escolas, com incentivos do governo por isenções tributárias de e-books e e-readers ${ }^{7,8}$ e aquisição de e-books para escolas públicas; e nas universidades, com o perfil do público leitor de e-books majoritariamente de jovens adultos universitários, subsetor CTP com títulos em

\footnotetext{
${ }^{7}$ Dados veiculados no jornal O Estado de S. Paulo, no artigo de 07 de maio de 2014. Disponível em: < http://cultura.estadao.com.br/noticias/geral,camara-discute-definicoes-para-e-books-imp-,1163299>. Acesso em: 15 maio 2014.

${ }^{8}$ Dados veiculados no jornal O Estado de São Paulo, no artigo de 21 de abril de 2014. Disponível em: <http://www.estadao.com.br/noticias/arte-e-lazer,crescimento-na-venda-de-e-books-no-brasil-devecontinuar-diz-especialista, 1156757,0.htm>. Acesso em: 30 abr. 2014.
} 
formato e-book ocupando o segundo lugar no faturamento total das editoras, assim como a expansão do Ensino a Distância $(E a D)^{9}$ e a demanda crescente por informações científicas de forma rápida pelo público acadêmico.

Apesar deste cenário favorável, a literatura aponta baixa adoção de e-books em bibliotecas:

- $\quad$ Nos EUA, mesmo sendo um dos maiores mercados neste ramo e com $3 / 4$ de suas bibliotecas públicas com serviço de empréstimo de e-book, a maioria dos usuários que compram ou baixam e-books, não utilizam ebooks disponibilizados pelas bibliotecas públicas, principalmente por falta de conhecimento dessa oferta (ALA, 2013);

- Nas bibliotecas acadêmicas, alguns autores apontam a necessidade de revisão de estratégias de divulgação, para que o uso aumente, como apontado por Bratanek (2013) no Canadá e pelo Joint Information Systems Committee (2009) no Reino Unido;

- No Brasil, autores como Moraes (2012), Pinksy (2009), e Velasco (2008) apontam a preferência por obras impressas e desconhecimento ou conhecimento superficial de e-books em universidades.

Neste sentido, surgiu a indagação que orienta a nossa pesquisa: haveria algum problema no serviço prestado pelas bibliotecas, no e-book ou em ambos para que o e-book tivesse baixo uso? A discussão que nos é provocada é em relação ao uso do e-book nas bibliotecas universitárias. Se os e-books não chegam aos usuários das bibliotecas, voltamo-nos a questionar se há adequação dos métodos, processos, produtos e serviços das bibliotecas, e como o serviço está sendo produzido nas bibliotecas acadêmicas? Ao falarmos sobre uso de e-book, não abordamos o aspecto cognitivo ou de usabilidade, mas o acesso do e-book a partir da biblioteca.

Assim, trazemos como pergunta de pesquisa: haveria problemas na produção do serviço de disponibilização de e-books na biblioteca universitária que afetem o uso de e-books nas bibliotecas? Que tipos de problemas podem estar relacionados?

\footnotetext{
${ }^{9}$ Os cursos de EaD demandam materiais didáticos digitais, os e-books poderiam suprir esta necessidade.
} 
Para entender o uso de um produto ou de um serviço é necessário se voltar ao usuário e analisar como um sistema de produção está atendendo às necessidades do usuário. Entendemos com Zarifian (2001) que a produção de um serviço só ocorre quando este é útil às atividades do destinatário, o serviço é o efeito nas condições da atividade do cliente/usuário, isto é, o foco está no resultado: "O serviço é o efeito, o resultado, nas condições de exercício da atividade [...]. Um serviço se propõe a produzir resultados úteis à atividade do usuário" (ZARIFIAN, 2001, p. 105).

Identificar e compreender as necessidades, características e problemas do cliente-usuário é preciso para que o serviço possa efetivamente atuar nas condições de atividade:

\footnotetext{
Haverá produção de serviço quando ocorrer uma conduta compreensiva, por mais curta que seja sua duração, conduta que parta dos problemas do cliente-usuário para tentar identificar soluções. Caso contrário, não há produção de serviço. (ZARIFIAN, 2001, p. 125, grifo do autor).
}

Os usuários da biblioteca universitária são alunos, professores e funcionários, majoritariamente alunos e professores, os quais são o foco de análise de nossa pesquisa. As atividades destes usuários na universidade estão ligadas ao ensinoaprendizagem e à pesquisa. O e-book pode ser uma ferramenta que facilita o acesso a conteúdos necessários para o desenvolvimento dessas atividades, pois possui o potencial tecnológico de reunir diversos títulos em um mesmo suporte de leitura e com disponibilidade em tempo integral, porém exige um dispositivo de leitura e na maioria das vezes conexão com internet. Além disso, é possível o uso de recursos multimídias e audiovisuais, incrementando os materiais que o professor pode utilizar em sala de aula. Pode também auxiliar pesquisadores adeptos ao movimento de acesso livre de publicações científicas e acadêmicas, pois permite a publicação de títulos sem a figura da editora.

Para gerenciar os e-books, as bibliotecas precisam dispor de plataformas e ferramentas digitais, pois o e-book é um suporte acessível somente em meio digital. As ferramentas de busca, os modelos de negócio utilizados pelas editoras, a capacitação de funcionários, as características técnicas do e-book e seus dispositivos de leitura, o atendimento e a comunicação com o usuário são elementos presentes na produção do serviço. A organização e a gestão da biblioteca para 
trabalhar estes elementos influenciam a geração de valor do serviço.

As bibliotecas como provedoras de acesso a informação podem fazer a ponte entre usuários e informação por meio do e-book também, podendo atingir melhor mais usuários. O problema de pesquisa é relacionado ao baixo uso de e-books nas bibliotecas, esta questão pode estar relacionada:

a) Ao próprio e-book: suas características técnicas intrínsecas e as incertezas que o permeiam por ser uma inovação;

b) Ao serviço produzido pelas bibliotecas;

c) As necessidades dos alunos e professores para realizarem suas atividades de ensino-aprendizagem e pesquisa: o que alunos e professores necessitam para realizá-las e o que a biblioteca oferece;

d) Aos modelos de negócio existentes e/ou;

e) À preferência por livros impressos pelos usuários.

Reconhecemos que estes aspectos se relacionam e interferem um no outro, porém, nossa perspectiva de análise do uso do e-book é a partir da biblioteca universitária, considerando-a como um sistema de produção, assim, nosso foco de análise será o serviço produzido pelas bibliotecas.

Esta pesquisa tem como objetivo geral analisar a gestão de e-book em biblioteca universitária, com o propósito de compreender melhor o uso de e-books na biblioteca e detectar possíveis problemas na produção do serviço. Neste sentido, uustifica-se a construção desta dissertação pois há poucos estudos sobre gestão de livros eletrônicos em bibliotecas no Brasil, e especificamente que tratem sob a perspectiva de produção de serviços. O mercado editorial de livros eletrônicos acadêmicos está crescendo, as bibliotecas universitárias procuram disponibilizar este tipo de material, porém ainda não há modelos de gestão de e-books no Brasil. Neste sentido, pretende-se com esta pesquisa de mestrado contribuir em estudos sobre gestão de livros eletrônicos em bibliotecas acadêmicas.

Para alcançar o objetivo geral, iremos desdobrá-lo em objetivos específicos:

1. Apresentar o ambiente externo: a rede de produção do livro eletrônico, reconhecendo as pressões externas para redistribuição de processos internos das bibliotecas; 
2. Mapear e analisar a produção do serviço de disponibilização de ebooks da aquisição até chegada ao usuário em um estudo de caso, afim de identificar pontos críticos e desafios na gestão de serviços;

3. Relacionar o novo conceito de serviço de biblioteca universitária proposto pela literatura com a gestão de e-books. 


\section{REFERENCIAL TEÓRICO}

\subsection{Livro eletrônico}

\subsubsection{Definição}

Não é consensual o conceito e a terminologia de livro eletrônico na literatura (GRAU; ODDONE; DOURADO, 2013; VASSILIOU; ROWLEY, 2008; RAO, 2003). Rao (2003) coloca as definições mais correntes: o e-book é um objeto (hardware) que comporta o conteúdo de um livro (propriedade intelectual); ou é o próprio conteúdo dentro de um hardware, ou ambos os conceitos. Ao contrário do livro impresso em que o conceito de suporte e conteúdo é indissociável, nos livros eletrônicos há esta separação, implicando até mesmo na sua definição. Furtado (2007) acrescenta outras problemáticas de definição encontradas na literatura: a digitalização de uma obra impressa pode ser considerada como um e-book, ou somente obras que foram elaboradas integralmente em meio digital, ou ambos? Furtado (2007) também observa entre os autores a distinção do e-book ora como objeto ora como obra/conteúdo.

Nesta pesquisa adotaremos apenas os termos livro eletrônico ${ }^{10}$ e e-book, compreendendo-o como o conteúdo (propriedade intelectual), seja concebido em meio impresso ou digital, mas que só pode ser acessado via um suporte eletrônico (hardware), podendo este suporte ser computadores, e-readers ${ }^{11}$, celulares, tablets, etc. Apesar da ambiguidade das definições encontradas na literatura, o fato de vários autores tratarem o livro eletrônico ora como suporte ora como conteúdo é relevante para analisar como os diversos elementos que compõem o e-book afetam alguns setores.

O e-book percebido como suporte/objeto tecnológico é composto por: dispositivo de leitura (hardware), software, formato do arquivo em que o e-book é gravado (pdf, ePub, etc) e a linguagem utilizada para descrever o e-book no arquivo (xml, txt, etc) (PROCÓPIO, 2010). Considerar o livro eletrônico como suporte e

\footnotetext{
${ }^{10}$ Alguns autores utilizam o termo livros digitais como sinônimo de livros eletrônicos, porém para fins de padronização utilizaremos apenas o termo livro eletrônico. (CORDÓN-GARCIA; GÓMEZ-DÍAZ; ALONSO-ARÉVALO, 2011; LUH-WANG, HUI-YI, 2010; OLIVEIRA, 2012; MCALLISTER, D.; MCALLISTER, N.; VIVIAN, 2002).

${ }_{11}$ Aparelhos eletrônicos específicos para leitura e armazenamento de e-books, serão detalhados no tópico 2.1.2 - Histórico.
} 
conteúdo permite vislumbrar algumas questões na comercialização e produção de ebooks com as quais editoras e livrarias se defrontam (OLIVEIRA, 2012), como incompatibilidade de formatos, armazenamento, direitos autorais, etc, os quais serão explicitados nos tópicos seguintes. O esquema a seguir ilustra os elementos constituintes do livro eletrônico:

Figura 3 - Elementos tecnológicos constituintes do livro eletrônico

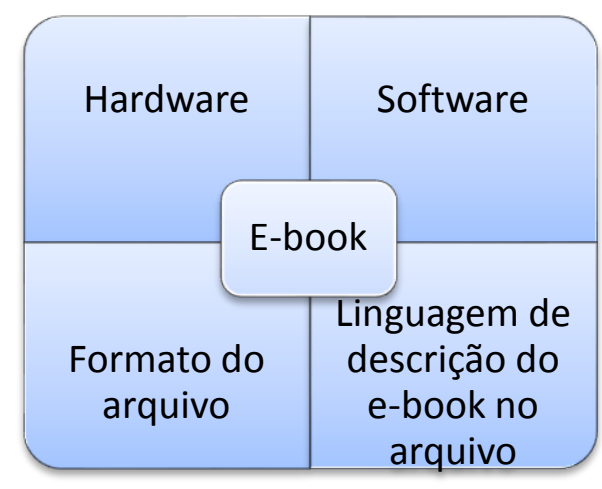

Fonte: autoria própria

Segundo Hawkins, 2000 apud Rao, 2003, os livros eletrônicos podem ser obtidos de duas formas:

- Arquivo: o usuário faz o download da obra que fica armazenada em seu hardware;

- Acesso: o usuário não faz download da obra, mas acessa no website, sistema e/ou plataforma do fornecedor da obra.

Sendo possível acessar por meio de download ou não, o acesso pode estar restrito a um determinado equipamento de leitura ou não, por exemplo, algumas empresas apenas disponibilizam títulos para e-readers (sendo que muitas vezes cada empresa trabalha com determinadas marcas de e-readers). A diversidade de formatos de arquivos (pdf, ePub, etc) também dificulta o acesso, autores como McAllister D., McAllister N. e Vivian (2002) e Luh-Wang e Hui-Yi (2010) tratam deste problema, nem todos os formatos, hardwares e softwares são compatíveis. Soma-se ainda, o fato de que algumas livrarias e fornecedores de e-books trabalham com apenas determinados tipos de formato de arquivo, softwares ou hardwares (geralmente e-readers específicos).

Outra problemática do elemento tecnológico: quando se obtém o e-book a partir do acesso, o leitor não adquire a posse, mas somente o acesso. Não é 
possível vender, emprestar ou dispor a obra conforme o leitor queira. Alguns autores criticam o e-book justamente pela ausência de controle do uso futuro que o leitor pode fazer (PROCÓPIO, 2010; CUBITT, 2013). Cubitt (2013) afirma que, neste sentido, os livros impressos são mais "livres" que os eletrônicos.

\subsubsection{Histórico}

Apesar da popularização do livro eletrônico ser recente, sua invenção não é. Em 1971, Michael Hart, norte-americano considerado o pai do e-book (PROCÓPIO, 2010), idealizou uma base de dados de livros disponíveis na íntegra, a partir disso, começou a digitalizar obras que estivessem em domínio público e/ou com a permissão do autor, no caso de estarem sob direitos autorais, assim surgiu o Projeto Gutenberg $^{12}$. Atualmente, o projeto conta com 42.000 obras digitalizadas e disponibilizadas em diversos formatos: ePub, html, arquivo para Kindle, etc. Voluntários realizam o trabalho e o projeto é financiado por doações.

Nos anos 1990 são desenvolvidos os primeiros dispositivos que armazenam milhares de páginas de livros, a ideia era criar uma biblioteca digital portátil. Nascem assim, os primeiros e-readers, como por exemplo: DEC Letrice Virtual Book, Dynabook da Sony, SoftBook Reader da SoftBook Press, Rocket e-book da NuvoMedia Inc. (PROCÓPIO, 2010), entre outros.

\section{Figura 4 - E-reader Rocket e-book}

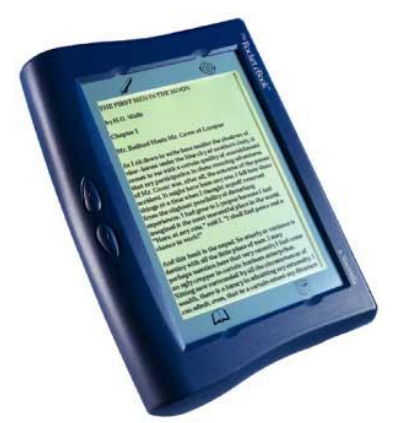

Fonte: Site ATPM ${ }^{13}$

A concepção de um objeto que pudesse armazenar livros, documentos, informações e imagens interligados em rede é atribuída a Vannevar Bush 
(PROCÓPIO, 2010; VELASCO, 2008), que em 1945 escreveu um artigo no periódico The Atlantic Monthly chamado As We May Think, no qual descreve uma máquina de leitura nomeada de MEMEX (MEMory EXtension, em português, memória extensiva). O MEMEX é considerado pela literatura como um precursor dos e-readers, a figura 5 ilustra o MEMEX.

Figura 5 - MEMEX

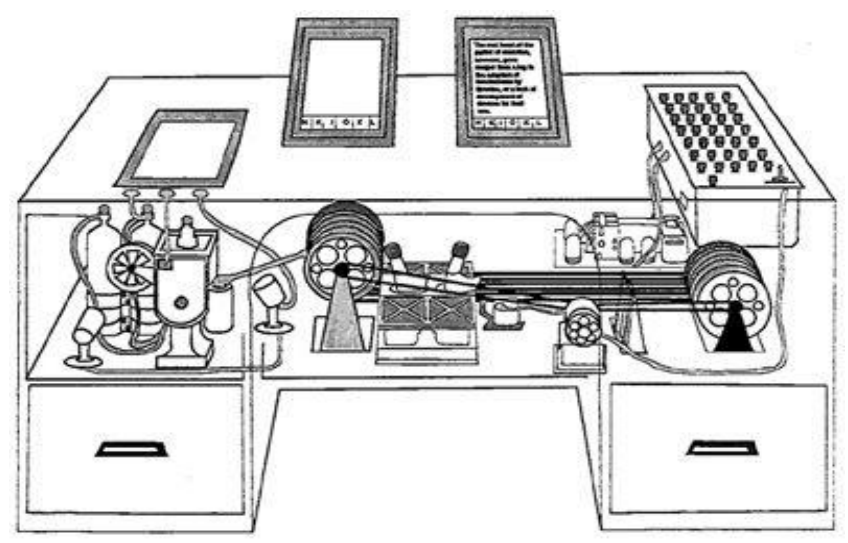

Fonte: Site if:book ${ }^{14}$

$\mathrm{Na}$ primeira metade dos anos 2000, a comercialização de e-books intensificou-se, mas sem ainda alcançar patamares significativos, o catálogo disponível de livros eletrônicos não era diversificado, com poucos idiomas, os preços não eram atrativos e os suportes de leitura não eram os mais adequados (HERTHER, 2005).

Em 2000, Stephen King, escritor norte-americano famoso por suas histórias de suspense e terror, foi o primeiro autor a lançar uma obra exclusivamente no formato digital, não sendo possível adquirir o livro impresso: Riding the Bullet poderia ser baixada na internet ao ser pago um pequeno valor (em torno de US\$ 2,50), aproximadamente 500 mil cópias foram vendidas em um final de semana (PROCÓPIO, 2010, p.156-7). Esta iniciativa foi marcante por apresentar uma obra literária acessível somente em mídias digitais e por colocar em xeque o papel do editor, rompendo a cadeia produtiva do livro ao publicar diretamente a obra na rede, sem uma editora.

\footnotetext{
${ }^{14}$ Figura disponível em: <http://www.futureofthebook.org/blog/archives/2005/02/finally_i_have_a_memex.html>. Acesso em: 05 fev. 2014.
} 
Em 2007, a Amazon comercializa em território norte-americano o Kindle, sendo em 2009, aberta a venda para demais países. O lançamento do Kindle é um fato significativo na história dos e-books por ser um e-reader com mais recursos para leitura e por integrar o aparelho com o catálogo da Amazon (ALMEIDA, 2012). A partir de então surgiram no mercado outros e-readers como Sony Pocket Edition, Nook da Barnes \& Noble, que junto com os softwares trazem funções mais sofisticadas (marcação de texto, dicionários, pesquisa na obra, recursos audiovisuais, hiperlinks, notas no texto, etc), além de evoluir a questão ergonômica da leitura (telas mais confortáveis em relação à luminosidade, tamanho das letras, cores, etc) (ALMEIDA, 2012). Nesta mesma época popularizaram-se os tablets, os quais forneciam recursos para leitura de e-books e ainda integravam funções dos computadores, ampliando os meios de acesso aos e-books.

O desenvolvimento do e-book e dos aparelhos eletrônicos ocorreu sem estar integrado a toda a cadeia produtiva do livro, tal fato implicando situações complexas e difíceis com as quais hoje leitores, editoras, bibliotecas, livrarias se deparam, como direitos autorais, empréstimo de obras, incompatibilidade de softwares e hardwares, entre outros.

\subsubsection{Agentes envolvidos}

O livro eletrônico está relacionado aos seguintes agentes: autores, editores, distribuidores, agregadores, livrarias e lojas virtuais, produtores de tecnologia e leitores.

\section{Autores}

Os autores são responsáveis pelo desenvolvimento do conteúdo e detêm a propriedade intelectual da obra. A partir da internet e softwares, com os e-books os autores podem publicar suas obras sem as editoras, fenômeno chamado de selfpublishing (autopublicação), além de divulgá-las e comercializá-las. No caso de autores de obras acadêmicas, há adesões ao movimento de comunicação científica livre, em que autores disponibilizam gratuitamente suas obras em plataformas online que não cobram ou não exigem algum tipo de propriedade sobre a obra. 


\section{Editores}

Apesar da tecnologia facilitar ao autor "pular" uma etapa da cadeia produtiva do livro, que é a publicação via editoras; essas exercem um papel essencial, não só na formatação da obra, mas na adequação editorial e na divulgação. Além disso, muitas editoras são reconhecidas como uma espécie de "selo da qualidade", títulos provenientes de determinadas editoras acabam adquirindo renome, ou então, algumas editoras por serem especializadas, os leitores acabam recorrendo-as por saberem que lidam com determinada temática. As editoras de certa forma exercem filtros, elas que irão selecionar o que irá ou não ao mercado consumidor e com que apresentação irá ao mercado (PINSKY, L., 2013; THOMPSON, 2005).

A relação entre editora-autor também é alterada em termos de questões contratuais. Os autores, comumente, assinam contratos vinculando sua relação com a editora até a edição do título se esgotar, entretanto, esta situação não existe nos e-books, assim, este é um ponto que necessita ser revisto entre autores e editores (PROCÓPIO, 2010).

Os editores trabalham em cima da obra do autor, lidando com seleção, formatação, linguagem, divulgação e vendas. Estão presentes em quase toda a cadeia produtiva do livro, atuando como um intermediador entre autor e mercado. $\mathrm{Na}$ figura 6, observa-se a atuação do editor em boa parte do processo de produção do livro impresso: 
Figura 6 - Cadeia produtiva do livro impresso

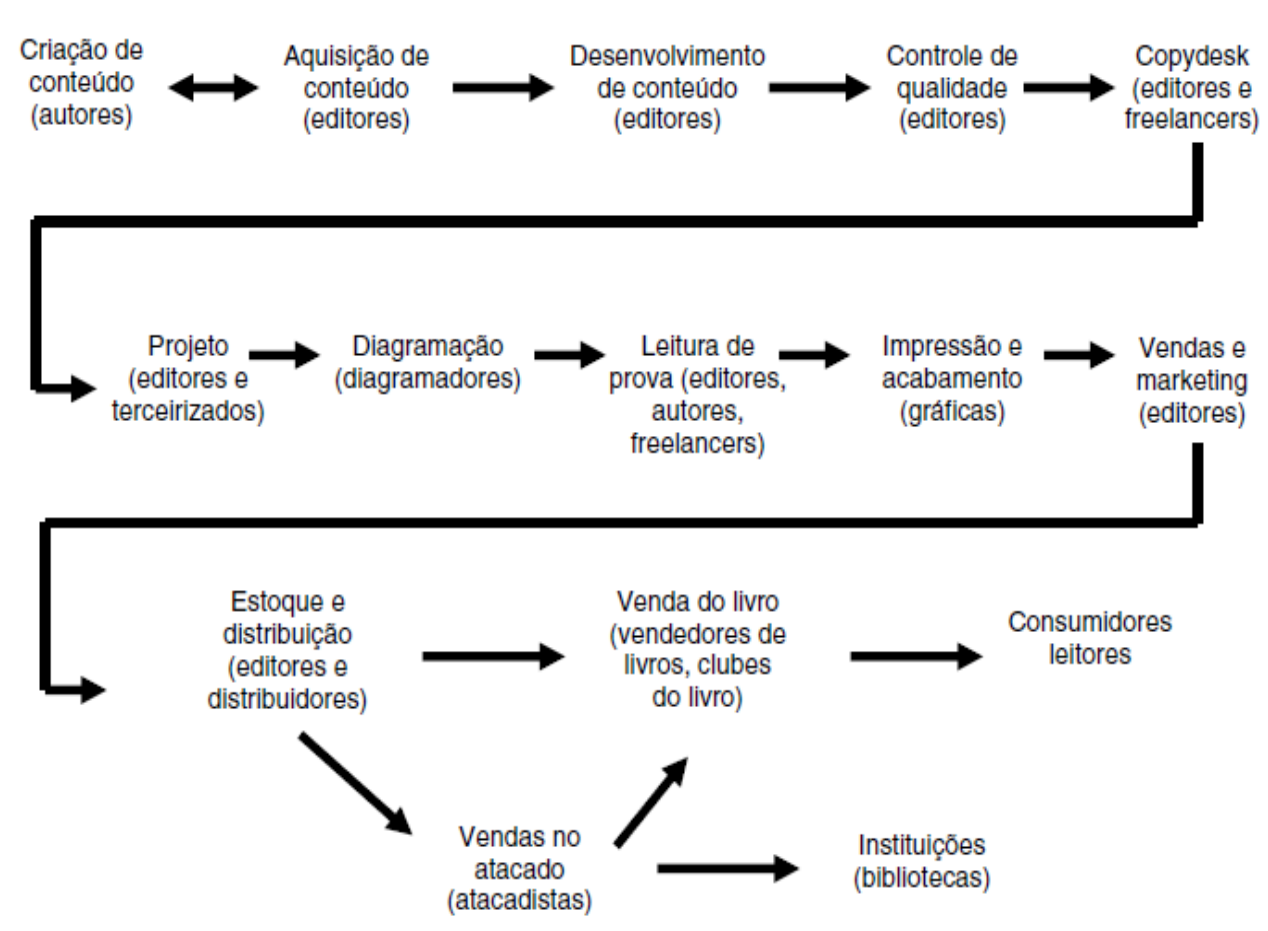

Fonte: Pinsky, D. (2009, p. 21)

Como discutido anteriormente, apesar da tecnologia permitir ao próprio autor divulgar e vender sua obra na internet ou qualquer outro meio, as editoras participam na atribuição de valor ao conteúdo. O livro é mais do que um produto, as editoras prestam serviços, segundo Pinsky, D.:

O editor não apenas decide o que será publicado ou não. Ele identifica espaços no mercado e dá ideias sobre que livros publicar, analisa a concorrência, conhece o público consumidor, busca o melhor escritor possível para dar andamento a determinada ideia [...]. Ou seja, o papel do editor é cada vez mais agregar valor ao conteúdo. Publicar é simples, publicar bem e adequar o texto ao público consumidor é mais complicado (2009, p. 22).

Ferreira Júnior (2011, p.10-1) ao pesquisar sobre servitização em editoras de livros didáticos aponta que até final dos anos 1970, o livro era visto como um bem físico pelas editoras, em que poucas partes da obra eram modificadas e que as editoras inclusive detinham parques gráficos para impressão. O livro passava por um processo de trabalho similar ao de uma linha de produção em que o objetivo principal era o processamento para impressão. Já a partir dos anos 1980, o 
conteúdo do livro começou a ganhar maior atenção das editoras, e a partir dos anos 2000 a impressão passou a ser terceirizada, de maneira que voltou-se para criação e disseminação de conteúdo. Estes dados, apesar de serem específicos aos livros didáticos, mostram um panorama mais geral do mercado editorial no Brasil. Atualmente, percebe-se que mesmo com as tecnologias aparentemente suprindo partes das funções de uma editora, elas não a substituem, pois o objetivo final das editoras não está mais concentrado na produção de um bem tangível - a impressão de um livro - mas na atribuição de valor, marca, qualidade ao conteúdo do livro, configurando-se como uma prestação de serviço e não uma fabricação de produtos.

As editoras preocupadas com a questão da pirataria de obras se cercam de mecanismos de proteção de direitos autorais, tanto em questão tecnológica como comercial. Para se certificar contra a cópia e distribuição ilegal, editoras e fornecedores de e-books trabalham com sistemas baseados em Digital Rights Management (DRM), os quais possuem técnicas de criptografia, especificando a forma como os usuários poderão acessar o conteúdo. Dentre delimitações de acesso, encontramos restrições e limites para: impressão, download, uso simultâneo por outros leitores, leitura em determinados softwares/hardwares, número de licenças de acesso à obra, etc.

O DRM também trabalha com o repasse de valores para autores e editoras, assim como quantifica cópias vendidas, acessos e downloads (LUH-WANG; HUI-YI, 2010; PROCÓPIO, 2010). Geralmente, comercializam-se livros em formato PDF com proteção contra cópias na plataforma Adobe Digital Editions. Estes mecanismos de proteção também suscitam a preocupação em relação à autenticidade da obra: como garantir que a obra distribuída é a original e não foi modificada? Além de recursos tecnológicos que restrinjam modificações na obra, o papel das editoras se faz presente novamente, uma instituição que cuida de um catálogo irá tomar medidas para garantir a integridade de seus títulos.

As editoras também vendem e-books diretamente à bibliotecas ou por meio de agregadores, distribuidores, livrarias e lojas virtuais. 


\section{Livrarias e lojas virtuais}

As livrarias e lojas virtuais oferecem e-books. A forma mais comum de comercialização para bibliotecas é por aquisição perpétua, porém o acesso não é simultâneo. Estes arquivos podem ser abertos somente na plataforma/app da livraria ou loja virtual, em determinados softwares ou licenciado somente para um ou mais tipos de suporte de leitura (hardware). É comum nestes casos que a biblioteca empreste e-readers ou tablets, porém este é um modelo menos praticado devido ao custo (DUARTE et al., 2013) e impossibilidade de uso simultâneo da obra.

É relevante ressaltar que para a comercialização do e-book geralmente as bibliotecas não detêm o título em seu servidor (PROCÓPIO, 2010). Em alguns casos, mesmo quando há aquisição de acesso perpétuo, há necessidade de pagamento periódico de taxas de manutenção da plataforma na qual a obra está alocada. As instituições, portanto, não criam suas próprias coleções virtuais, caso não renovem as assinaturas ou deixem de pagar taxas de manutenção perderão os títulos.

\section{Agregadores}

São empresas que representam diversas editoras e licenciam o conteúdo em sua plataforma própria, com sistemas DRM. Trabalham com grandes quantidades de títulos e com menor espaço para negociação, porém trabalham com diversos modelos de negócio (SERRA, 2014, p.43).

\section{Distribuidores}

Também trabalham com distribuição dos livros na plataforma do editor, diferentemente do agregador que atua em sua própria plataforma. Possuem mais flexibilidade de negociação do que os agregadores (SERRA, 2014, o, 44). Utilizam também sistemas DRM para controle de direitos autorais.

\section{Produtores de tecnologia}

Assumem um papel mais importante na produção do livro eletrônico do que na do impresso. Na cadeia produtiva do livro a impressão, a estocagem e a distribuição de livros são operações fundamentais, que perdem relevância quando 
se trata de livros eletrônicos. Por outro lado, a editoração digital, a criptografia e o ecommerce ganham força. A gama de produtos e serviços oferecidos é diversa: desenvolvimento, comercialização e fornecimento de softwares, hardwares e formatos de arquivos, os quais oferecem suporte para armazenamento, leitura, produção, edição, proteção de direitos autorais, distribuição e venda.

Procópio (2010) aponta que o desenvolvimento de tecnologias para livros eletrônicos está mais avançado que os modelos de negócio existentes, estas tecnologias foram criadas sem estar necessariamente no mesmo compasso que a evolução do mercado editorial. Contudo, a tecnologia influencia diretamente no modelo de negócio dos e-books, de modo que este segmento se torna estratégico na rede de produção do livro: "[o negócio do livro] à medida em que tem o e-book em suas estratégias de venda, passa a estar atrelado, cada vez mais, às ações e aos produtos resultantes das empresas de Tecnologia de Informação" (OLIVEIRA, 2012, p. 8).

\section{Leitores}

Por fim, os leitores. O leitor pode tanto ser o cliente que compra livros em livrarias, sites, sebos, etc, como pode ser o usuário de bibliotecas e demais instituições que mantêm acervos. As vantagens do livro eletrônico para o leitor são várias: armazenamento, espaço, inexistência de estoques e edições esgotadas, recursos como ferramentas de pesquisa, dicionários, tradutores, links, conteúdos audiovisuais, comunicação com outros leitores em redes sociais, marcadores de texto, criação de notas, etc.

Contudo, o leitor poderá se deparar com incompatibilidade de formatos, softwares e hardwares, restrições de uso, indisponibilidade de leitura offline. No caso de usuários de bibliotecas, o leitor enfrentará maiores dificuldades, devido às restrições mais severas aplicadas a essas instituições.

O hábito de leitura também é modificado, o leitor necessita dominar uma tecnologia para ler uma obra:

Nos últimos anos, a tecnologia chega ao consumidor, que volta a ter de aprender a ler um livro. Não basta folhear as páginas daquele códice tão familiar há várias gerações. Agora é preciso saber quais são os dispositivos de leitura, o que cada um oferece, como comprar um livro digital e, sim, como virar a página de um livro que nem página tem. (PINSKY, L., 2013, p. 160). 
Relacionamento entre os agentes

As relações entre os agentes da cadeia de produção do livro no contexto dos e-books são mais diversificadas do que na cadeia de produção do livro impresso, conforme esquematizamos na figura 7 . 
Figura 7 - Rede de produção do livro eletrônico

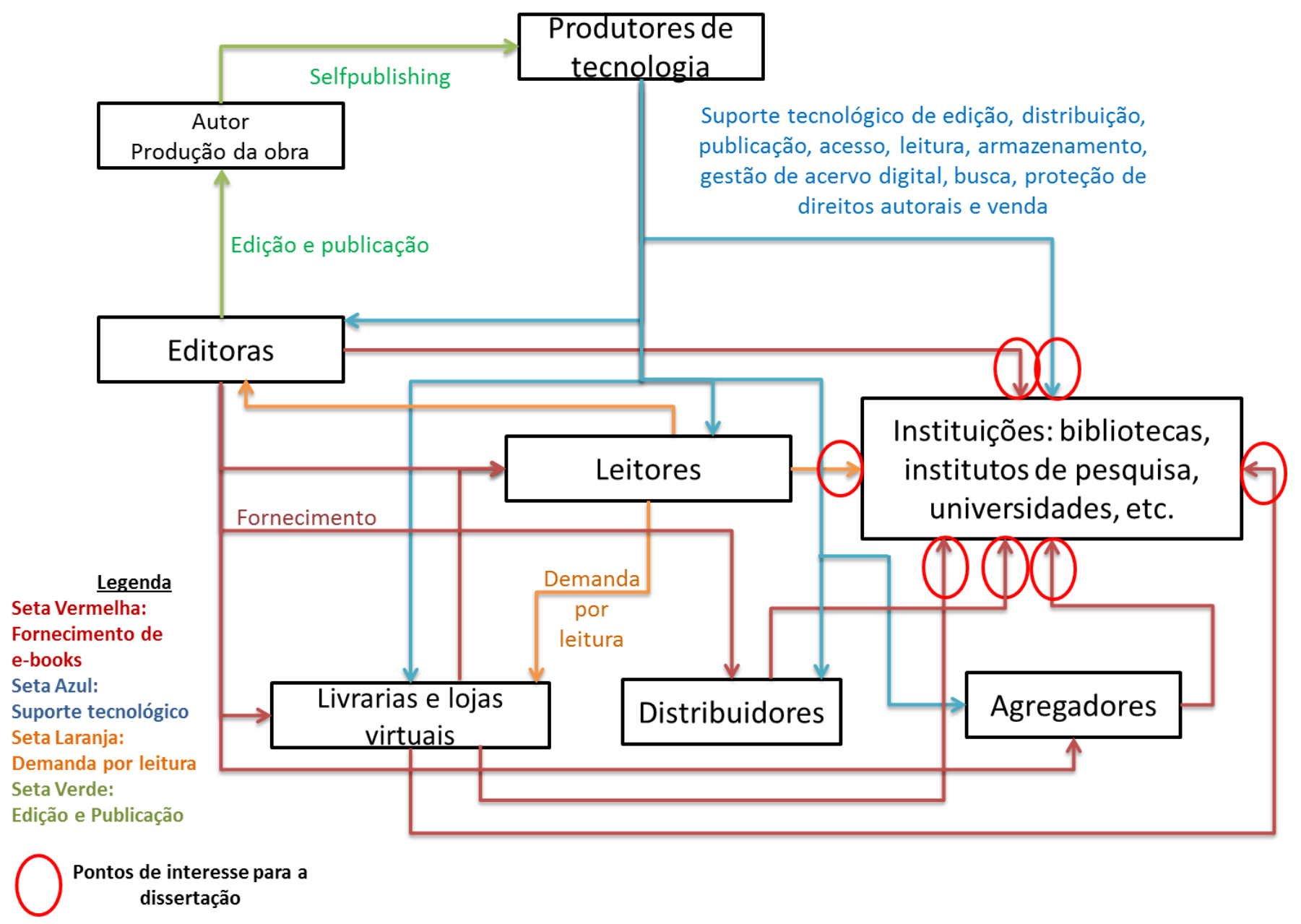

Fonte: A partir de Bacalgini e Silva (2013, p. 06). 
A figura apresenta três tipos de relações diretas com a biblioteca: fornecimento de e-books, suporte tecnológico e demanda por leitura, sendo que estas relações compõem a análise desta dissertação.

As editoras, livrarias, lojas virtuais, agregadores e distribuidores de bases de dados são fornecedores de e-books, os quais apresentam as condições de comercialização e acesso da obra. Os produtores de tecnologia oferecem suporte tecnológico de acesso, leitura, busca, armazenamento e gestão de e-books às bibliotecas. Em ambos os casos há influência no modo como as bibliotecas produzem o serviço de disponibilização de e-books: o custo deste serviço, o conhecimento necessário para usuários e funcionários utilizarem esta tecnologia, as formas de aquisição, a divulgação e a capacitação aos usuários, a capacitação de funcionários, a busca de títulos pelos usuários e a gestão das obras. Uma outra relação poderia ser criada na figura: a especificação de produtos e serviços pelas bibliotecas aos fornecedores de e-books e aos produtores de tecnologia. As bibliotecas poderiam trabalhar em conjunto com estes agentes da rede de produção para indicar formas de acesso (uso simultâneo, acesso de partes ou toda a obra, permissão de impressão, etc), aquisição (acesso ou arquivo), pagamento, busca de título e filtros de pesquisa, interface e linguagem utilizada nas bases de dados, relatórios de estatísticas de uso, exportação de registros bibliográficos de e-books, entre outros, a fim de modelar o produto que desejam receber de acordo com as necessidades de seus usuários. Atualmente, é o mercado de e-books que impõe condições de compra e uso às bibliotecas.

Apesar do mercado de e-books não ser recente, presente desde os anos 1990 (SHAW, 2010), o modelo de negócios do e-book ainda está em desenvolvimento. Os principais modelos de negócio são:

- Assinatura de bases de dados: os livros ficam disponíveis somente durante o período de vigência da assinatura. No caso de bases de dados de e-books, os fornecedores podem deixar o cliente escolher título a título ou vendê-los por pacotes; ainda pode existir ou não a opção de trocar os títulos no momento da renovação da assinatura. Para as bibliotecas, pode existir algumas limitações como: uso simultâneo de um e-book, número de usuários simultâneos na base de dados, número de acessos por obra, downloads (capítulo, íntegra ou proibição), impressão, condição de comprar o e-book 
junto com o exemplar impresso, embargos (a empresa pode colocar um período de espera para que as bibliotecas possam ter acesso às edições mais recentes ou liberar o acesso imediato mediante um valor mais alto), etc;

- Acesso perpétuo: não é necessário realizar renovações de assinatura para continuar a se ter acesso a obra. Alguns fornecedores trabalham com taxas de manutenção da plataforma que a instituição utiliza para disponibilizar títulos, neste caso, para continuar a se ter acesso é necessário pagamento periódico desta taxa;

- Pay-per-view: a instituição paga somente aquilo que o usuário requisitar. $O$ título fica disponível durante um determinado período ao usuário e expira após o uso. Dependendo do contrato, após um determinado número de acessos o título poderá ficar disponível para empréstimo, sem que a biblioteca tenha que pagar por cada acesso solicitado;

- PDA (Patron Driven Acquisition - Aquisição voltada ao usuário): a biblioteca adquire somente as obras acessadas pelos usuários, uma vez obtido o acesso, torna-se permanente ou disponível por um longo período determinado. A biblioteca poderá ser comunicada sobre a aquisição quando ultrapassar critérios, como por exemplo, número mínimo de páginas lidas ou download de capítulos;

- Empréstimo virtual ou STL (Short Term Loan - aluguel por curto período): o título é emprestado ao usuário por um determinado período, a quantidade de usuários que podem emprestar simultaneamente e o período de empréstimo são acordados no contrato. A biblioteca não precisa adquirir ou assinar a obra, mas paga uma taxa por título pelo empréstimo do livro;

- Aluguel de e-books: comumente desenvolvido para pessoas físicas e não jurídicas, o usuário paga uma assinatura para se ter acesso aos livros de um catálogo, cada fornecedor aplica uma política de uso sobre o serviço.

O e-book apresenta potenciais tecnológicos, como o uso simultâneo que elimina questões como tempo de empréstimo, reservas, renovações, permitindo acesso a títulos por 24 horas / 7 dias da semana, porém tais potenciais são suprimidos ou minimizados pelos modelos de negócio. Ao comercializar, por exemplo, o acesso de um título limitado a um usuário por vez, a lógica de comercialização do livro eletrônico se aproxima do impresso (LUH-WANG; HUI-YI, 
2010; OLIVEIRA, 2012). Benghozi e Salvador (2013) ao estudarem sobre Pesquisa e Desenvolvimento na indústria editorial indicam um processo de absorção-imitação ao invés de reação e mudanças:

\begin{abstract}
O que, de fato, ainda está faltando é um modelo de negócio real dos editores para o e-book: parece que casas editoriais estão seguindo as necessidades do mercado sem exercer efetivamente o papel de líderes. Como consequência, investimentos em $\mathrm{P} \& \mathrm{D}$ e inovação não estão ligados à criação de um modelo de negócio real, mas principalmente para a visibilidade. Isso significa que a estratégia editorial atual está mais focada em manter seu lugar secular e o papel dos editores na cadeia de valor contábil através de um processo de adaptação em imitação em vez de atualizar seu papel e função a este novo ambiente emergente e instável e às mudanças de hábitos culturais. (BENGHOZI; SALVADOR, 2013, não paginado, tradução nossa).
\end{abstract}

Luh-Wang e Hui-Yi (2010) apontam alguns elementos que um modelo de negócio para publicações digitais poderia se atentar: explorar os e-books não somente na questão da leitura, mas combinar a integração de diversas mídias e meios de comunicação, permitindo compartilhamento de opiniões entre leitores, criação de comunidades de discussão e demais recursos de interação. Além disso, trabalhar na integração de conteúdos e gostos do público.

A precificação do e-book também é outra problemática ainda não estabelecida no mercado editorial: por serem digitais, os livros não são mais impressos, reduzindo ou eliminando alguns custos das editoras como impressão, estocagem e transporte (JIANG; KATSAMAKAS, 2010). Este fator influencia na precificação dos livros eletrônicos: apesar de num primeiro momento parecer que isto significa o barateamento do produto, o e-book traz outros custos até então inexistentes às editoras e fornecedores como gerenciamento de mecanismos de DRM, plataformas de comércio digital para e-books, edição digital, entre outros. LuhWang e Hui-Yi (2010) apresentam que o estabelecimento de mecanismos de precificação de e-books precisaria ser distinto dos livros impressos.

Um fator problemático às bibliotecas é em relação ao compartilhamento de títulos entre instituições. A prática da cooperação é comum nas bibliotecas, com empréstimos entre bibliotecas, serviços de comutação bibliográfica e aquisições cooperativas. Contudo, o acesso ao e-book é atribuído mediante licenças às bibliotecas, não há meios de compartilhamento de licenças, inibindo o compartilhamento de coleções (GARROD, 2004). 
De certa forma, os produtores de tecnologia estão mais a frente do que o mercado editorial. Desenvolvimento de softwares, formatos e hardwares para ebooks foi realizado sem conexão com o mercado editorial, exemplo disso foi o surgimento dos e-readers (PROCÓPIO, 2010), assim a tecnologia evoluiu primeiro do que as modalidades de comercialização.

A adaptação da biblioteca é pressionada por leitores, por fornecedores de ebooks com seus modelos de negócio e pela própria tecnologia que traz novidades tecnológicas e desafios operacionais às bibliotecas.

Para apresentar 0 ambiente externo que influencia o setor de e-books, utilizaremos o modelo PESTEL. A escolha deste modelo se deve ao fato de que abrange diversos aspectos de um setor de produção, além de facilitar apresentação. O modelo PESTEL analisa as influências Políticas, Econômicas, Sociais, Iecnológicas, Écológicas e Legais de um setor (JOHNSON; SCHOLES; WHITTINGTON, 2008, p. 55).

As bolas verdes indicam elementos que favorecem o desenvolvimento de ebooks no Brasil, as bolas amarelas são elementos ainda em desenvolvimento e as bolas vermelhas criam obstáculos: 
Quadro 1 - Modelo PESTEL para e-books

\begin{tabular}{|c|c|}
\hline & Tecnológico \\
\hline $\begin{array}{l}\text { Compra de tablets e e- } \\
\text { books para escolas } \\
\text { públicas; } \\
\text { Inclusão de e-books no } \\
\text { Portal de Periódicos da } \\
\text { CAPES. }\end{array}$ & $\begin{array}{l}\text { Desenvolvimento de hardwares } \\
\text { e softwares para e-books; } \\
\text { Self-publishing; } \\
\text { Softwares para controle de } \\
\text { acesso, uso e direitos autorais; } \\
\text { E-commerce. }\end{array}$ \\
\hline Econômico & Ecológico \\
\hline $\begin{array}{l}\text { Métodos de precificação de } \\
\text { e-books; } \\
\text { Preço do e-reader; } \\
\text { Preço do e-book; } \\
\text { Modelo de negócio ainda } \\
\text { não consolidado. }\end{array}$ & $\begin{array}{l}\text { Redução do uso de papel; } \\
\text { Descarte de baterias } \\
\text { equipamentos eletrônicos. }\end{array}$ \\
\hline Social & Legal \\
\hline $\begin{array}{l}\text { Hábitos de leitura; } \\
\text { Expansão de EaD. }\end{array}$ & $\begin{array}{l}\text { Direitos autorais; } \\
\text { Contratos comerciais de } \\
\text { editoras e fornecedores de } \\
\text { livros; } \\
\text { Contratos com autores. }\end{array}$ \\
\hline
\end{tabular}

Fonte: autoria própria.

A aquisição de títulos eletrônicos e tablets para escolas, a inclusão de ebooks no Portal de Periódicos da CAPES, a expansão do Ensino a Distância, o aprimoramento das tecnologias para uma leitura mais confortável e com mais recursos, a facilidade de publicação de livros diretamente pelos autores e uma infraestrutura já existente para comércio eletrônico fortalecem a rede de produção do livro eletrônico, com exceção do self-publishing que afeta negativamente às editoras, porém é um ponto positivo aos autores que desejam editar suas obras.

Por outro lado, aspectos econômicos e legais enfraquecem a rede, pois colocam restrições ou dificuldades a leitores e a instituições compradoras de livros: preços de equipamentos eletrônicos de leitura; grandes editoras e fornecedores de 
livros não trabalham com os mesmos equipamentos; limitações de download, impressão e número de licenças de instalação em dispositivos eletrônicos, cujas condições se encontram nos contratos; receios quanto a pirataria e plágios impulsionam editoras, livrarias e fornecedores de bases de dados ao controle de direitos autorais e contratos comerciais com mecanismos que colocam limitações aos benefícios da tecnologia. Todos estes fatores expressam um modelo de negócio que não é voltado à lógica digital, mas sim à do impresso.

O hábito de leitura por impressos é um fator social que impacta editoras, fornecedores de livros e setores ligados a produção de tecnologia, por ser historicamente e culturalmente estabelecido, configura-se como uma barreira a ser quebrada ao negócio de e-books. Com relação ao aspecto ambiental, os e-books trazem o benefício da supressão do uso do papel para impressão, porém criam o problema do lixo eletrônico.

\subsection{As atividades dos usuários}

As atividades dos usuários da biblioteca universitária estão ligadas ao ensinoaprendizagem e à pesquisa. Quando abordamos bibliotecas de universidades é importante destacar que as universidades se caracterizam por trabalhar com ensino, pesquisa e extensão, já as faculdades, institutos superiores e escolas superiores não tem a exigência de atuar com pesquisa, focando-se mais em ensino (PEREIRA, 2007, p. 42). Estes diferentes enfoques podem impactar nas coleções e nos serviços prestados pelas bibliotecas. A pesquisa bibliográfica é valorizada na atividade de pesquisa, desta maneira, a relação com a biblioteca é fundamental, a qual irá adquirir, tratar e promover acesso às informações necessárias. As atividades de ensino-aprendizagem exigem também pesquisa bibliográfica assim como materiais didáticos e pedagógicos para o desenvolvimento de atividades em aula e extraclasse. A biblioteca universitária além de provedora de materiais, documentos e demais informações necessárias para as atividades de pesquisa e ensinoaprendizagem, pode atuar como mediadora, orientando professor e aluno sobre a confiabilidade de fontes de informações, no desenvolvimento de estratégias de busca, na escolha de fontes para publicação, em estudos bibliométricos, entre outros.

O docente deve planejar suas atividades de ensino (SEVERINO, 2008), elaborando atividades, materiais, metodologias de ensino e avaliações que auxiliem 
os alunos no processo de aprendizagem, utilizando laboratórios, recursos audiovisuais e bibliográficos, etc. O objetivo de sua atividade é que alunos adquiram conhecimentos, mas também se envolvam na construção do aprendizado (ANASTASIOU; ALVES, 2005), desenvolvendo competências e habilidades. A biblioteca com o serviço de disponibilização de e-books pode auxiliar o professor na indicação de e-books que ofereçam recursos audiovisuais de forma a enriquecer a preparação da aula, assim como o e-book tem o potencial tecnológico de permitir que toda a classe tenha acesso ao título.

Aos alunos está reservada a atividade de aprender, por meio do estudo, prática, experimentação, entre outros métodos. $O$ aluno não é sujeito passivo que recebe conhecimentos, mas participa do processo de ensino em conjunto com o professor (MASETTO, 2012), trabalhando em atividades extraclasse e debatendo com o professor a matéria da disciplina, construindo o objeto de aprendizagem. A biblioteca, além de disponibilizar conteúdos necessários para as atividades dos alunos, pode a partir dos e-books indicar acesso a obras de forma mais rápida e os discentes podem utilizá-la independentemente do horário de funcionamento da biblioteca. A biblioteca auxilia também os alunos na busca de obras relevantes e de credibilidade.

Pereira (2007) apresenta o ensino de graduação como um sistema de produção, com inputs, processos e outputs, esquematizando-o conforme a figura 8 : 
Figura 8 - Sistema de produção para o ensino de graduação

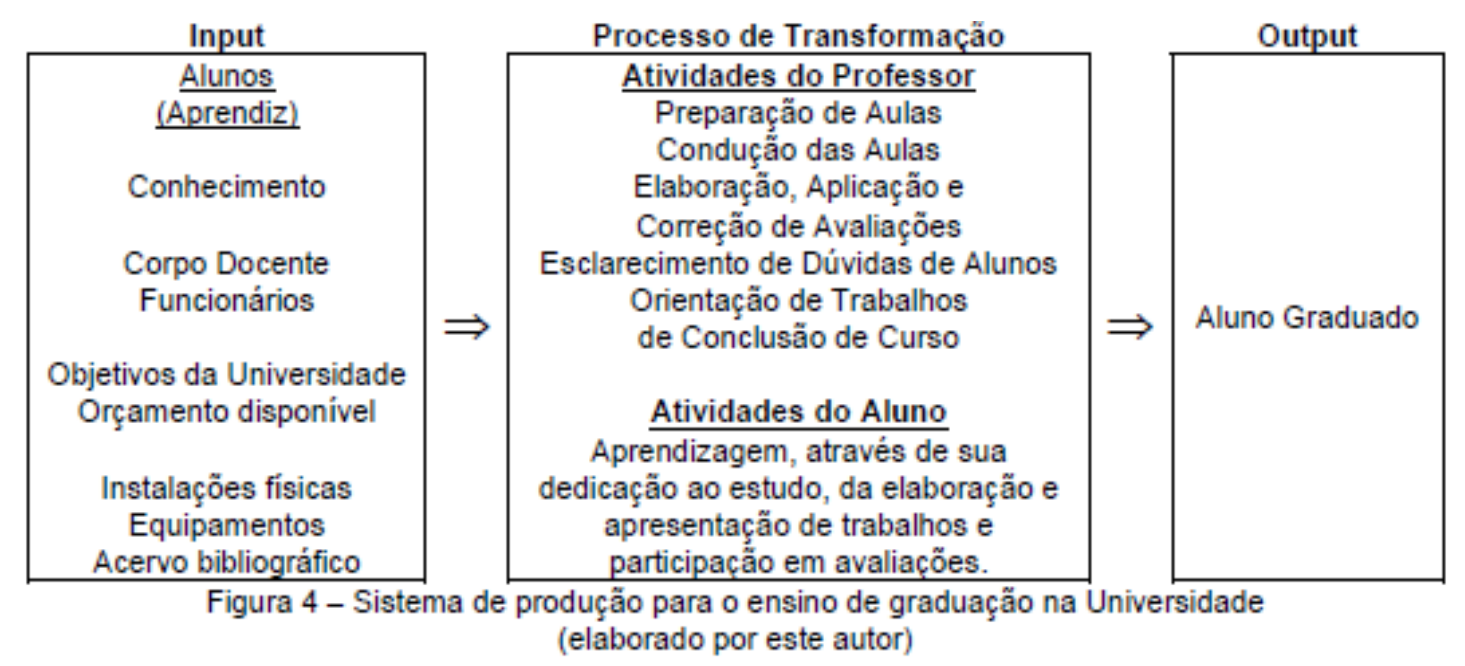

Fonte: Pereira (2007, p. 49).

No modelo de Pereira (2007) cabe à biblioteca o papel de input, sendo vista como acervo bibliográfico, a biblioteca possui uma relação estática com o professor e o aluno em que somente fornece insumos para as atividades de ensino. No ponto de vista desta pesquisa, a biblioteca possui papel ativo no ensino, sendo que o valor do seu serviço é auxiliar as atividades de ensino-aprendizagem, mais do que fornecedora de coleções, a biblioteca apoia seus usuários, norteando os caminhos para se encontrar a informação necessária e produzindo cursos e conteúdos relevantes para suas atividades acadêmicas.

\subsection{A biblioteca universitária}

A biblioteca universitária tem como principal missão oferecer acesso à informação, apoiando as atividades de ensino, pesquisa e extensão. As bibliotecas auxiliam na preservação e socialização do conhecimento produzido na universidade (FUJITA, 2005). O acesso à informação se dá de duas maneiras: acesso físico e o cognitivo/intelectual, de acordo com Kuhlthau (2004, p. xv, tradução nossa): "O acesso físico trata de localização de fontes e informações. Acesso intelectual indica interpretação/análise de informações e idéias nas fontes".

Para atingir seu papel, a biblioteca necessita tanto dispor de meios para que seu usuário encontre e obtenha a informação, como também apresentá-la em grau de complexidade, abrangência e idioma compatíveis com as necessidades e perfis 
do usuário, oferecendo condições para acesso cognitivo da informação.

A figura do usuário é central na orientação, concepção e no delineamento de produtos e serviços (DIAS; PIRES, 2004, p. 07), mas há também a demanda da instituição mantenedora - a universidade, a qual define público-alvo, autonomia e estrutura organizacional da biblioteca. Mesmo que o usuário seja balizador na definição de produtos e serviços, estes estão sujeitos à missão e à demanda institucional. A biblioteca necessita conciliá-las: que a demanda institucional não enrijeça a estrutura e processos da biblioteca, mas também que a demanda de usuários não flexibilize excessivamente os serviços oferecidos a ponto de não ter como comportar a demanda dentro de sua estrutura, deixando de prestar um serviço adequado.

A fim de atender aos usuários e promover o acesso à informação, a biblioteca universitária tem como atividades principais: desenvolvimento de coleções, preservação, organização e tratamento da informação, divulgação e apoio à pesquisa. Estas atividades nas bibliotecas são geralmente dispostas organizacionalmente em dois setores: Tratamento da informação (ou Processamento técnico), cujo objetivo está em selecionar, incorporar, tratar, organizar e preservar fontes de informação; e Referência, a qual foca na divulgação, atendimento, capacitações e pesquisa destas fontes de informação. Na primeira, o contato com usuário é indireto; na segunda,o contato é direto. Nos quadros 2 e 3, procuramos esquematizar as funções e as atividades da biblioteca : 
Quadro 2 - Tratamento da informação

\begin{tabular}{|c|c|c|}
\hline Atividade & Descrição & Objetivo \\
\hline $\begin{array}{l}\text { Desenvolvimento de } \\
\text { coleções, composto das } \\
\text { atividades de: } \\
\text { ○ Estudo de } \\
\text { usuários; } \\
\circ \text { Seleção; } \\
\circ \text { Aquisição; } \\
\circ \text { Preservação; } \\
\circ \text { Avaliação; } \\
\circ \text { Descarte. }\end{array}$ & 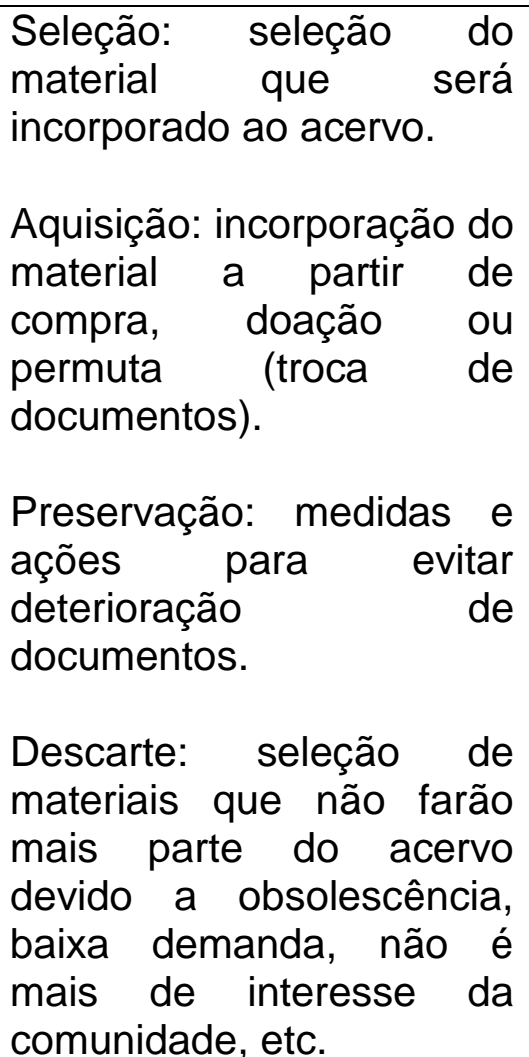 & $\begin{array}{lr}\text { Formar } & \text { coleções } \\
\text { compatíveis com as } \\
\text { necessidades } & \text { dos } \\
\text { usuários, } & \\
\text { preservando-a } \\
\text { mantendo-a } \\
\text { atualizada. }\end{array}$ \\
\hline Catalogação & $\begin{array}{l}\text { Descrição e representação } \\
\text { de dados dos documentos. }\end{array}$ & $\begin{array}{l}\text { Possibilitar } \\
\text { recuperação da obra } \\
\text { por meio dos dados } \\
\text { descritos. }\end{array}$ \\
\hline Classificação & $\begin{array}{l}\text { Atribuição de códigos a fim } \\
\text { de organizá-los no acervo. }\end{array}$ & $\begin{array}{l}\text { Arranjo de coleções e } \\
\text { recuperação de obras } \\
\text { a partir dos códigos } \\
\text { atribuídos. }\end{array}$ \\
\hline Indexação & $\begin{array}{l}\text { Atribuição de assuntos aos } \\
\text { documentos. }\end{array}$ & $\begin{array}{lr}\text { Recuperação } & \text { de } \\
\text { documentos } & \text { por } \\
\text { assunto. } & \end{array}$ \\
\hline $\begin{array}{l}\text { Elaboração de fichas } \\
\text { catalográficas }\end{array}$ & $\begin{array}{l}\text { Confecção de fichas } \\
\text { catalográficas a partir de } \\
\text { dados da obra. }\end{array}$ & $\begin{array}{l}\text { Identificação de obras } \\
\text { publicadas. }\end{array}$ \\
\hline
\end{tabular}

Fonte: autoria própria. 
Quadro 3 - Referência

\begin{tabular}{|c|c|c|}
\hline Atividade & Descrição & Objetivo \\
\hline Atendimento & $\begin{array}{l}\text { Atividades referentes a } \\
\text { empréstimo, devolução, } \\
\text { reservas e renovação } \\
\text { de materiais. }\end{array}$ & $\begin{array}{l}\text { Permitir a circulação de } \\
\text { obras. }\end{array}$ \\
\hline $\begin{array}{ll}\text { Orientação } & \text { na } \\
\text { normalização } & \text { de } \\
\text { trabalhos acadêmicos }\end{array}$ & $\begin{array}{l}\text { Auxílio no uso de } \\
\text { normas técnicas para } \\
\text { padronização } \\
\text { trabalhos acadêmicos. }\end{array}$ & $\begin{array}{ll}\text { Normalização } & \text { de } \\
\text { trabalhos acadêmicos. }\end{array}$ \\
\hline $\begin{array}{l}\text { Divulgação de serviços } \\
\text { e produtos }\end{array}$ & $\begin{array}{lr}\text { Apresentação, } & \\
\text { comunicação } & \text { e } \\
\text { interação com usuários } \\
\text { sobre } & \text { serviços e e } \\
\text { produtos. } & \end{array}$ & \begin{tabular}{ll} 
Usuários & \multicolumn{2}{c}{ atualizados } \\
sobre os serviços da \\
biblioteca.
\end{tabular} \\
\hline Pesquisa & $\begin{array}{lr}\text { Orientação } & \text { na } \\
\text { elaboçãa } & \text { de } \\
\text { estratégias } & \text { de } \\
\text { pesquisas, busca } & \text { de } \\
\text { revistas para publicação } \\
\text { e levantamento } \\
\text { bibliográfico. }\end{array}$ & $\begin{array}{l}\text { Encontrar a informação } \\
\text { necessária para as } \\
\text { demandas do usuário. }\end{array}$ \\
\hline Capacitações & $\begin{array}{l}\text { Cursos sobre como } \\
\text { fontes de informação, } \\
\text { bases de dados, } \\
\text { serviços e produtos da } \\
\text { biblioteca. }\end{array}$ & Capacitar usuários. \\
\hline Comutação bibliográfica & $\begin{array}{l}\text { Fornecimento de cópias } \\
\text { de artigos de periódicos, } \\
\text { capítulos de trabalhos } \\
\text { acadêmicos, etc. }\end{array}$ & $\begin{array}{l}\text { Oferecer acesso a fontes } \\
\text { de informação. }\end{array}$ \\
\hline
\end{tabular}

Fonte: autoria própria.

Utilizaremos alguns autores, dicionários e glossários específicos da área de Ciência da Informação (ARRUDA; CHAGAS, 2002; CUNHA; CAVALCANTI, 2008; SANTOS; RIBEIRO, 2003) a fim de apresentar com maior detalhamento estas atividades. 


\section{Tratamento da informação}

O desenvolvimento de coleções implica na "constituição e planejamento de acervos que sejam reflexos de uma comunidade específica" (VERGUEIRO, 1989, p. 39). Para tanto, a biblioteca universitária utiliza como critérios para a seleção de documentos que farão parte de seu acervo: bibliografias básicas e complementares de cursos, sugestões da comunidade acadêmica, perfil dos usuários e linhas de pesquisa da universidade. Desenvolve também critérios para seleção de doações: pertinência temática, temporal, condições físicas dos livros, incorporação ou não de coleções de volumes completos, exigências de acondicionamento/exposição da obra pelo doador, etc. A renovação e preservação da qualidade do acervo também implica no descarte de obras que não são mais de interesse da comunidade, tenham baixa demanda, restrições de espaço físico, condições físicas da obra, etc. É possível também a incorporação de obras por meio de permuta, a partir da troca de obras com outras instituições. Ainda há a realização periódica de inventário do acervo para verificar se há obras perdidas e/ou furtadas, mantendo o controle do acervo.

A função de preservação está relacionada a " [...] todas as ações que visam retardar a deterioração e possibilitar o pleno uso dos bens culturais." (APCR, 2005). Em relação a acervos impressos, os cuidados são com higienização, controle de condições ambientais (iluminação, umidade, temperatura), armazenamento, transporte e manipulação de documentos.

Para acessar o documento incorporado ao acervo é necessário registrar dados da obra a fim de recuperá-la por alguma ferramenta de pesquisa. Nesta etapa, fazem-se necessária catalogação, classificação e indexação. A primeira se refere à descrição e à representação do documento, para identificá-lo e recuperá-lo. A segunda abrange a codificação de documentos sob determinado critério, geralmente temático, permitindo o arranjo do documento no acervo, sendo que o usuário localiza a obra no acervo por meio destes códigos (comumente numéricos ou alfanuméricos). Por último, a indexação se refere à atribuição de assuntos por meio de vocabulários controlados da instituição, a fim de que os usuários possam encontrar obras de um mesmo assunto a partir de diversos termos.

Por fim, parte da produção acadêmica necessita de fichas catalográficas, as quais são elaboradas por bibliotecários. 
Produtos resultantes:

- Inventário;

- Catálogo online / serviço de descoberta online;

- Repositório intitucional online;

- Vocabulários controlados;

- Acervo organizado;

- Catalogação na fonte (elaboração de fichas catalográficas).

Serviços resultantes:

- Seleção de obras de interesse à comunidade e aquisição destas;

- Oferecimento de meios para que os usuários possam encontrar a obra no acervo a partir das atividades de catalogação, classificação e indexação;

- Controle e preservação do acervo para que todos possam ter e continuem a ter acesso às obras.

\section{Referência}

As atividades ligadas à Referência envolvem atender buscas por informações relacionadas às atividades acadêmicas, mas também curiosidades ou motivações pessoais. Grogan coloca que a Referência: "[...] não é simplesmente fornecer informações, mas atender a essas necessidades cognitivas" (1995, p.22), aproximando-se do conceito de acesso físico e cognitivo de Kuhlthau (2004).

Dentre as tarefas desempenhadas pelos bibliotecários na Referência estão: atender a demandas de pesquisa de informações, apoio na escolha de periódicos para publicação, levantamento bibliográfico, normalização e padronização de trabalhos acadêmicos, assim como capacitações sobre o uso de ferramentas de pesquisa, fontes de informação, serviços e produtos da biblioteca. Há também atividades desenvolvidas no balcão de atendimento como empréstimo, devolução, reserva e renovação de obras.

$\mathrm{Na}$ Referência se trabalha também com divulgação, comunicando e interangindo com seu público-alvo sobre produtos e serviços, regras, notícias e novidades da biblioteca, utilizando diversos meios de comunicação como murais, folhetos, e-mails, redes sociais, sites, palestras, entre outros. 
As atividades de Referência envolvem contato mais próximo com o usuário do que as atividades de Tratamento da informação. Interagir com o usuário é fundamental para compreender seus problemas e demandas e assim atendê-lo com eficácia.

Produtos resultantes:

- Trabalhos normalizados e padronizados;

- Listas de levantamento bibliográfico;

- Materiais de divulgação e capacitação.

Serviços resultantes:

- Orientação à pesquisa e publicação;

- Atendimento ao usuário (circulação do acervo);

- Orientação sobre normalização e padronização de trabalhos acadêmicos;

- Capacitações;

- Divulgação.

As bibliotecas universitárias são subordinadas à estrutura da universidade, são hierarquizadas e com funções bem definidas (JANTZ, 2012, p.31). Possuem geralmente três divisões hierarquizadas: administrativa, técnica (Tratamento da informação) e atendimento ao usuário (Referência), cada qual se desdobra em subdivisões por função ou atividade (AL-ANSARI, 1999). Estruturam-se em torno do acervo, sendo suas coleções o centro de todas as atividades (AL-ANSARI, 1999; TRAVICA, 1999). Observamos nas bibliotecas universitárias o predomínio de divisão de trabalho altamente definida e específica, com divisões baseadas em funções e atividades. Apesar do contexto de cada biblioteca, percebe-se uma homogeneidade em suas estruturas organizacionais.

\subsubsection{Mudanças nas bibliotecas universitárias com as tecnologias}

Com a popularização da Internet e das TICs (Tecnologias de Informação e Comunicação), as tecnologias foram incorporadas às atividades das bibliotecas, 
trazendo algumas alterações, como automatização de atividades (como por exemplo: renovação e reserva), serviços online (pesquisas em catálogos e bases de dados online), comunicação virtual com usuários, intercâmbio eletrônico de registros de catálogos entre bibliotecas, etc.

Nas bibliotecas universitárias o ambiente é de incertezas, além das mudanças na indústria de publicações com documentos digitais e diferentes modelos de negócio, o ensino superior e a comunicação científica também foram impactadas, trazendo mais transformações às bibliotecas. Apresentamos na figura 9 alguns dos impactos que as TICs trouxeram às bibliotecas acadêmicas:

Figura 9 - Mudanças tecnológicas e os impactos nas bibliotecas universitárias

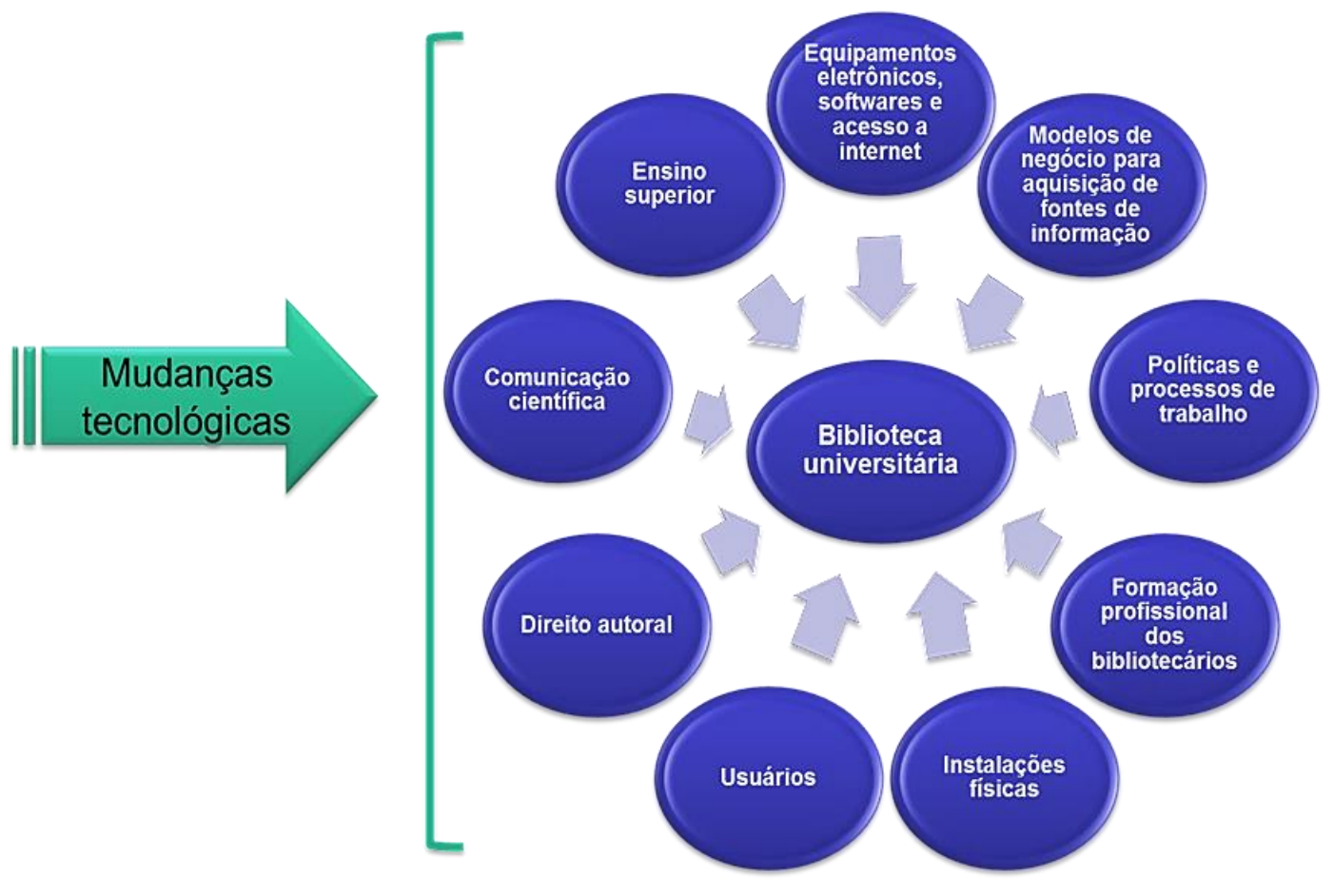

Fonte: Bacalgini e Silva (2015, p.2).

Percebe-se que as TICs não trazem apenas impactos no uso de equipamentos ou rotinas de trabalho, mas estão relacionadas a estruturas que alteram serviços das bibliotecas e demandas, como direitos autorais (questões de propriedade intelectual e preservação digital).

$\mathrm{Na}$ comunicação científica percebemos a biblioteca não mais somente como provedora de informação, a qual era sua função no modelo tradicional de comunicação e produção científica, mas atualmente passa a assumir funções na 
produção da pesquisa, como seleção de canais de publicação, manutenção de repositórios institucionais, gestão de pre-print e pos-print, etc. (KROLL; FORSMAN, 2010). Observa-se na figura 10, a biblioteca apenas com a função de fornecedora de informação:

Figura 10 - Modelo tradicional de comunicação e produção científica

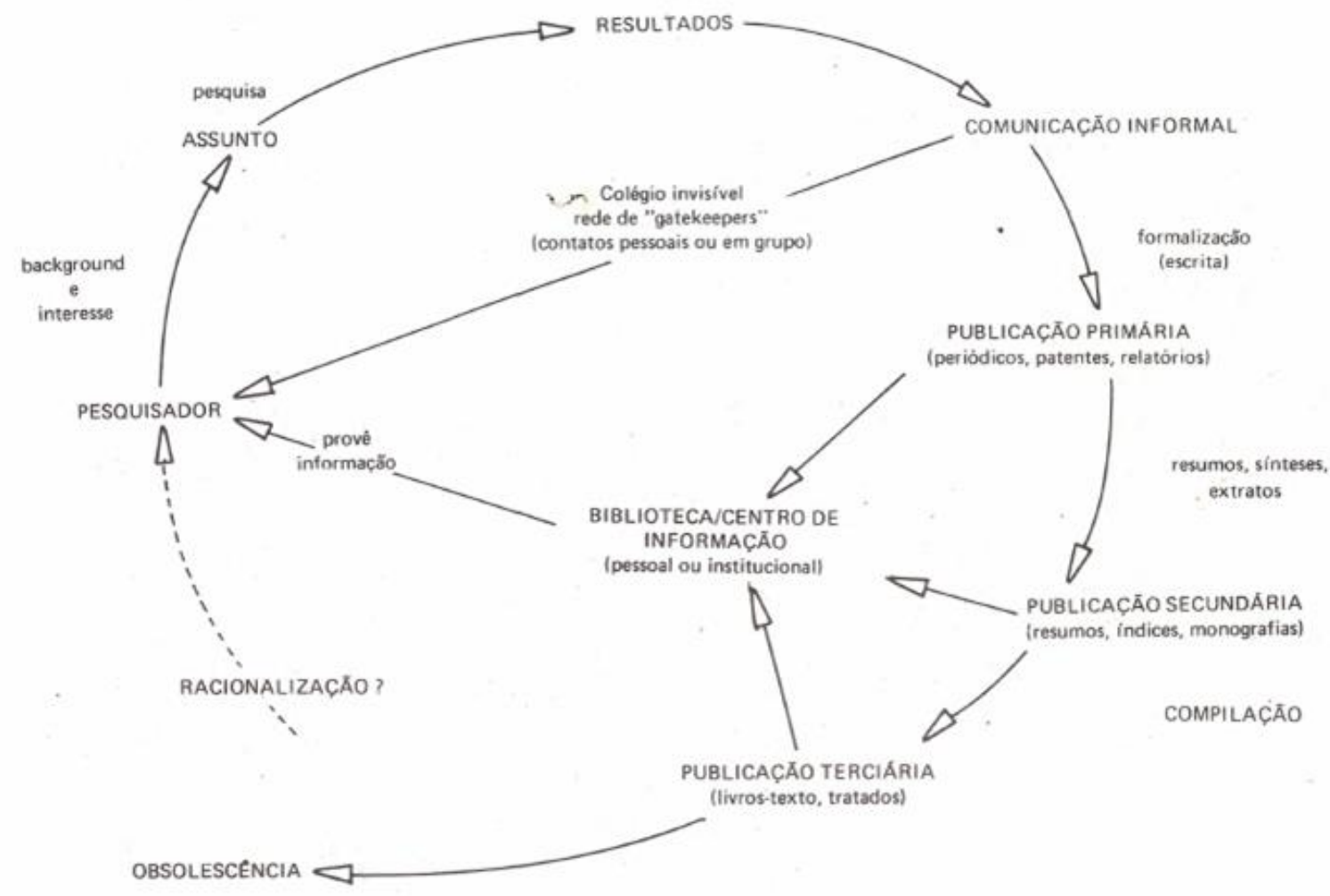

Fonte: Araújo (1979) ${ }^{15}$ apud Modesto (2011).

As formas de ensino à distância no ensino superior são outra demanda que chegam às bibliotecas universitárias: como interagir com estes alunos e apoiá-los nas atividades acadêmicas?

Em relação ao espaço físico, os documentos digitais trazem como um dos benefícios a liberação de espaço. Cunha (2010) apresenta um debate na literatura sobre esta questão: alguns autores relatam que as novas bibliotecas deveriam ser menores, contrariamente, outros colocam que devem ser criados novos usos para

\footnotetext{
${ }^{15}$ ARAÚJO, V. M.R. H. de. Estudo dos canais informais de comunicação técnica: seu papel na transferência de tecnologia e na inovação tecnológica. Ciência da Informação, v. 8, n. 2, p. 79-89, 1979.
} 
os espaços das bibliotecas, como salas para estudos e grupos de trabalho integradas com novas mídias.

As reduções orçamentárias nas universidades acabam por refletir nas bibliotecas, as quais possuem uma verba menor para aquisição de obras. Além disso, muitas com espaço físico limitado acabam por mudar ligeiramente sua política de desenvolvimento de coleções do que Cunha (2010) nomeia de just-in-case para just-in-time, ao invés de ter um grande acervo para no caso de surgir uma demanda (just-in-case), a biblioteca passa a adquirir documentos somente após a requisição do usuário (just-in-time). Esta mudança é facilitada por alguns modelos de negócio de e-book como PDA ou Pay-Per-View. Cunha (2010), contudo, ressalta que é cedo para supor quais serão os tipos de alterações nas políticas de desenvolvimento de coleções a longo prazo.

Os repositórios institucionais (RI) também impulsionam alterações, definidos como "[...] como uma ferramenta capaz de armazenar, preservar e proporcionar acesso livre a toda produção científica de uma determinada instituição" (MARRA, 2012, p. 182), os repositórios são desenvolvidos em softwares específicos e disponíveis gratuitamente na web, têm o objetivo de preservar e oferecer maior visibilidade a produção acadêmica. As bibliotecas universitárias em conjunto com reitoria e pesquisadores necessitam criar políticas para gerenciá-los, atentando-se a questões de: responsabilidade de arquivamento, manutenção da qualidade dos metadados dos arquivos, administradores das coleções, autorizações de publicação de documentos, etc (CUNHA, 2010).

Todos os conteúdos digitais trazem à biblioteca a questão da preservação digital: evitar obsolescência tecnológica para acesso de dados, manter controle, segurança e autenticidade de documentos e metadados. Algumas bibliotecas optam por trabalhar com editoras e fornecedores que são conveniadas a projetos de preservação digital como Portico e LOCKSS, pois mesmo que estas entidades entrem em falência, o acesso a suas coleções está garantido. Ambos os projetos trabalham com soluções tecnológicas para auxiliar instituições e empresas a manter acesso a conteúdos digitais de suas coleções (DIAS, WEBER, 2013; SILVA, SILVA, MATIAS, 2014). Portico e LOCKSS tratam também da proteção da propriedade intelectual, pois procuram garantir a manutenção da autenticidade dos documentos, conservando o acesso a um documento íntegro, não modificado. 
Como bibliotecas, universidades e instituições de pesquisa disponibilizam seus acervos a muitos usuários, editoras, agregadores e distribuidores possuem maior temor em relação a distribuição ilegal e ao plágio. Consequentemente, as restrições impostas são mais severas podendo até mesmo editoras se negarem a vender e-books a bibliotecas (IDOETA, 2012). O controle dos direitos autorais da obra pelas editoras traz impactos às bibliotecas.

No periódico Searcher, um artigo de Novembro de 2011 relata sobre o crescimento da venda de e-books, porém com restrições de vendas às bibliotecas, empresas como Macmillan e Simon \& Schuster não comercializam títulos para as bibliotecas, já a Harper Collins vende somente 26 acessos a seus títulos, ao ultrapassar este número a biblioteca deixa de ter este título na base de dados, devendo comprar mais 26 acessos caso queira novamente obtê-los (TONKERY, 2011, p. 37). No portal de notícias da BBC Brasil, uma matéria de Janeiro de 2013 anuncia que além destas editoras, a Hachette também se nega a vender e-books a bibliotecas, já a Random House aumentou o preço dos e-books para as bibliotecas (IDOETA, 2012).

Todas estas mudanças às bibliotecas levantam questões quanto à capacitação e à formação de bibliotecários: a biblioteca não é somente usuária de tecnologias (AMIN; GERBIC, 2010), mas desenvolvedora também de conteúdos digitais a partir da tecnologia. Há necessidade de conhecimentos de publicação e edição digital, manutenção de conteúdos online, criação de tutoriais e cursos online, assim como de habilidades gerenciais e dinamismo para o bibliotecário se posicionar e atuar neste ambiente incerto (HUFF-EIBL; VOYLES; BREWER, 2011; KUMBHAR, 2012; SAUNDERS, 2012; HUVILA et al., 2013; VIEIRA; BAPTISTA; CERVERÓ, 2013; MACEVICIUTE, 2014).

Alguns autores colocam que $O$ atual conceito de serviço das bibliotecas universitárias não atende mais as novas demandas e desafios (ORERA-ORERA, 2007; CASTRO FILHO, 2008; SENNYEY, ROSS, MILLS, 2009; CUNHA, 2010; FURNIVAL, GRACIOSO, 2011; JANTZ, 2012a, 2012b; MICHALAK, 2012; FINNEMANN, 2014; GRADMANN, 2014; MACEVICIUTE, 2014). O conceito atual e consolidado é a biblioteca como difusora de informação, a qual foca seus serviços para o acesso a informação. Apesar deste conceito de serviço ainda ser importante, não é mais suficiente, pois os próprios usuários já estão alcançando meios de encontrar a informação (armazenada em bases de dados assinadas e coleções 
mantidas por bibliotecas ou pesquisas por meio de sites de busca), os usuários demandam auxílio em gerenciar, organizar e analisar as informações encontradas, requisitam a produção de instrumentos que os auxiliem a usar a informação. Desta maneira, as bibliotecas a cada dia se envolvem mais na produção de conteúdos online, tutoriais, responsabilizam-se por manutenção de repositórios digitais, auxiliam na editoração de periódicos online, maior envolvimento na comunicação científica, assim, a biblioteca não é mais um canal para encontrar informação, mas é um suporte para produção de informação.

Este novo conceito de biblioteca universitária, encontra-se em bibliotecas acadêmicas na Espanha com o CRAI (Centro de Recursos para el Aprendizaje y la Investigación). Tradicionalmente, a biblioteca assume um papel de apoio ao ensinoaprendizagem na universidade, mas o CRAI propõe que seja um papel estratégico: a biblioteca passa a participar de planos pedagógicos, produção de materiais didáticos, apoio no ensino de idiomas, aproximação de grupos de pesquisa, deixando de ser um espaço restrito a busca de obras do acervo, e se tornando um centro agregador de serviços ligados ao ensino-aprendizagem que originalmente não se encontram na biblioteca, como por exemplo, recepção de calouros, laboratório de idiomas, suporte para elaboração de materiais didáticos, etc.

A biblioteca no CRAI não tem como centro de suas atividades o acervo, mas o usuário. $O$ acesso à informação é trabalhado não no sentido restrito de se localizar e obter a informação, mas no sentido de formar usuários para o uso de serviços, tecnologias e fontes informacionais. Assim, a biblioteca deve estar preocupada não só em capacitações, mas com o desenvolvimento de competência para pesquisa, uso e apropriação da informação (DOMÍNGUEZ AROCA, 2005; CASTRO FILHO, 2008). Esta nova concepção de biblioteca surge dentro do contexto europeu, o qual vivencia novos métodos de ensino-aprendizagem, novas formas de gestão na universidade e inovações tecnológicas. Especificamente em relação ao ensino, a formação está voltada para o desenvolvimento da autonomia do aluno e para seu aprendizado contínuo: o próprio aluno necessita gerenciar seus projetos de pesquisa e trabalhos acadêmicos (CASTRO FILHO; VERGUEIRO, 2011).

Para abrigar as atividades e serviços da biblioteca de acordo com essa nova concepção, um novo uso do espaço físico se faz necessário, como um lugar de encontro, compartilhamento e socialização na universidade, mas esta redefinição exige primeiramente mudança do estilo de gestão da biblioteca e de vários setores 
da universidade, depois é necessária a integração de profissionais de outras áreas, novos equipamentos, suporte tecnológico com apoio de especialistas da área, etc (DOMÍNGUEZ AROCA, 2005; ORERA-ORERA, 2007; CASTRO FILHO; VERGUEIRO, 2011).

O CRAI é um exemplo da aplicação deste novo conceito de serviço de biblioteca, deixa de ser difusora para produtora de informação. Algumas características deste novo conceito: interdisciplinariedade (equipes interdisciplinares e maior relacionamento da biblioteca com outros departamentos da universidade), autonomia do usuário, personalização de serviços, gestão mais flexível, espaço físico voltado para auxiliar o usuário a produzir (laboratórios, equipamentos, salas de estudo e debate), competência informacional, figura do bibliotecário como educador (orienta e ensina usuários no uso e busca de recursos de informação, além da produção de materiais didáticos), entre outros.

A competência informacional é relevante neste cenário, pois as bibliotecas enquanto produtoras da informação buscam desenvolver habilidades em seus usuários para elaboração de estratégias de busca, uso crítico de recursos de busca, análise e avaliação de fontes de informação e que consigam usar a informação encontrada de forma contextualizada, formando desta maneira usuários competentes informacionais, tornando-os mais autônomos (DUDZIAK, 2003; IFLA, 2006; UNESCO, 2007).

Portanto, percebemos que as bibliotecas estão envoltas não somente em mudanças tecnológicas, mas conceituais, alterando a própria concepção de seus serviços.

\subsubsection{As bibliotecas como produtoras de serviços e provedoras de conteúdos}

Conforme visto, as bibliotecas produzem produtos e serviços, mas o que entendemos como produtos e serviços? A diferenciação entre os dois termos é uma tarefa árdua, na medida em que as atividades econômicas e industriais são diversas e cada vez mais complexas e integradas com diversos setores (BOWEN; FORD, 2002). Segundo Bowen e Ford (2002), os serviços se caracterizam pela intangibilidade, perecibilidade, cliente como co-produtor e não somente consumidor e simultaneidade no processo de produção e uso, ao contrário de produtos, os quais são tangíveis, passíveis de armazenamento e estoque, não necessariamente 
exigem a presença do cliente na produção, além disso, critérios de mensuração são menos subjetivos e de caráter mais quantitativo do que em serviços.

Há diversos autores que tratam do tema, alguns com definições provenientes de diferentes perspectivas e enfoques. Uma das definições clássicas e da abordagem tradicional é de Ray Wild (1977), o qual considera serviço como a transformação do estado do cliente. Schmenner (1995) entende também serviço como transformação, porém não somente isto e afirma que se observam na literatura dificuldades na definição de serviço.

Zarifian (2001) propõe uma definição de serviço diferente da abordagem tradicional: serviço não será a transformação de um bem, de uma situação ou do estado da realidade do destinatário do serviço, mas sim a transformação da condição da atividade do destinatário, por exemplo: o serviço do metrô, por exemplo, na abordagem tradicional seria o transportar o cliente, há uma transformação da realidade do cliente (deslocamento), porém, para Zarifian (2001) o serviço de transporte será diferente para cada pessoa, dependendo das suas atividades, condições e percepções. Para um turista é importante que o serviço compreenda informações em outros idiomas, mapas, indicação de estações próximas a locais turísticos, etc. Já para o cidadão do local tais referências não são relevantes, pois as atividades que ele desempenha na cidade são outras, assim, a condição em que se encontra é outra. Portanto, um mesmo serviço pode ter efeitos distintos sobre seus usuários, pois a necessidade deles pode ser diferente. $\mathrm{Na}$ abordagem tradicional, o serviço prestado seria igual, pois se entende como serviço de metrô o deslocamento de pessoas e não como o metrô afetaria as atividades de seus usuários.

Desta maneira, identificar e entender o cliente-usuário é necessário a fim de que o serviço chegue ao nível das condições de atividade. Zarifian (2001) coloca que a produção de serviço só ocorre quando fornece solução para os problemas dos clientes-usuários. Adotamos a definição de serviço a partir de Zarifian (2001), pois entendemos que para a biblioteca a relação próxima com os usuários e a compreensão de seus problemas é fundamental para auxiliá-los em suas atividades acadêmicas.

Outro ponto que foge da abordagem tradicional de gestão de serviços é o valor de serviço. Zarifian (2001, p. 125) coloca que identificar e compreender necessidades do usuário e propor soluções é o que gera valor no serviço, ao 
contrário da abordagem tradicional, cujo foco é no custo-desempenho do serviço, estimulando a escolha do serviço baseado na importância dele em si e não em relação ao usuário. A produção do serviço seria um diálogo de compreensão das necessidades do usuário e não a venda/oferecimento do mesmo. Desta maneira, a competência profissional está voltada a questões comunicacionais.

O valor de serviço é composto de duas partes: o valor para o usuário, ou seja, a utilidade do serviço ao usuário (eficácia) e o valor de produção, referente ao custo de produção (eficiência). Zarifian subordina o valor de produção ao valor para o usuário, contrariando a lógica produtivista e comercial, em que produzir e vender mais por menos é o objetivo de muitas empresas, mas para Zarifian o importante é solucionar problemas dos clientes com o serviço. Faz-se necessário nesta dissertação também se atentar a esta questão de valor, a biblioteca na produção do serviço de disponibilização de e-books necessita mobilizar esforços e recursos para atender o valor para o usuário.

O sucesso para a produção do serviço depende tanto de quem oferece como de quem usa, desta maneira, a apresentação do serviço e a formação do usuário são elementos importantes. Para a nossa pesquisa, divulgação e capacitações sobre o serviço de disponibilização de e-books serão observados. Johnston e Clark (2002) apontam uma questão que pretendemos observar no serviço de disponibilização de e-books das bibliotecas: o conceito de serviço proposto pela biblioteca é o mesmo de seus usuários? Os autores não definem serviço, mas discutem sobre o conceito de serviço que uma instituição deseja projetar e operacionalizar:

[...] o conceito de serviço é o modo como 'a organização gostaria de ter seus serviços percebidos por seus clientes, funcionários, acionistas e financiadores' (HESKETT, 1996); em outras palavras, o conceito de serviço é a proposição do negócio. O conceito de serviço é [...] a figura mental formada por clientes". "É o serviço imaginado" (JOHNSTON; CLARK, 2002, p. 58).

Os autores ressaltam que é comum o cliente ter uma noção diferente do serviço proposto pelas empresas, gerando expectativas frustradas. Para evitar esta situação, os autores apontam quatro elementos que devem constar e estar claros na apresentação do conceito de serviço: 
- Experiência do serviço: experiência direta do processo de serviço pelo cliente; diz respeito à forma como o fornecedor do serviço lida com o cliente;

- Resultado do serviço: o que o cliente recebe;

- $\quad$ Operação de serviço: o modo como o serviço será entregue;

- Valor do serviço: o benefício que os clientes percebem estar coerente com a ponderação do serviço em relação a seu custo. (JOHNSTON; CLARK, 2002, p.59)

Johnston e Clark (2002), relacionam os elementos do conceito de serviço e os esquematizam na figura 11 :

Figura 11 - Conceito de serviço de Johnston e Clark (2002)

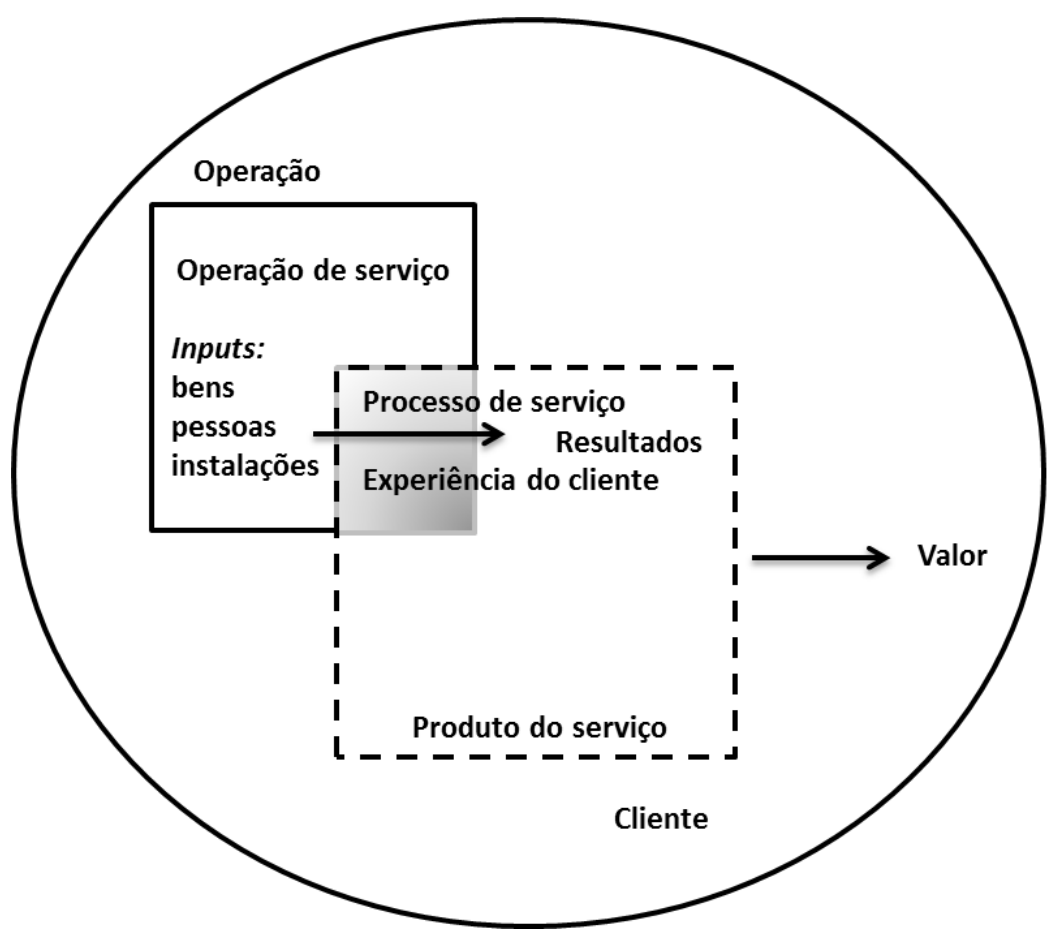

Fonte: Johnston e Clark (2002, p. 60).

Detectar percepções destoantes do proposto versus esperado é relevante para verificar se os usuários conhecem que tipo de serviço de e-books eles têm à sua disposição.

Uma das atividades mais importantes da biblioteca é a orientação à busca de informações, a qual é um serviço essencialmente intangível e que necessita do usuário como co-produtor; em outras atividades, como seleção e aquisição de materiais, o usuário não está presente na produção, mas suas necessidades, preferências e perfis impactam diretamente na produção. Os elementos subjetivos e 
qualitativos de serviços tornam mais complexa a análise da produção, entrega e apresentação destes.

Zarifian (2001) ressalta a importância de conhecer as atividades dos usuários e suas necessidades, pois o serviço só é efetivamente produzido quando é útil ao destinatário. Este é um conceito relevante para nossa pesquisa, observar se o modo como o serviço é produzido apresenta utilidade às atividades acadêmicas do usuário.

Aplicando os conceitos de Johnston e Clark (2002) podemos analisar o conceito de serviço de biblioteca em: Operação (detalhando em input e processo), Produto (resultados), Valor e Clientes (usuários no caso das bibliotecas), assim, temos esquematizado no quadro 4 :

Quadro 4 - Conceito de serviço de biblioteca universitária: difusora versus produtora de informação

\begin{tabular}{|c|c|c|}
\hline $\begin{array}{l}\text { Elementos-chave do } \\
\text { conceito de serviço }\end{array}$ & Difusora da informação & Produtora de informação \\
\hline Operação de serviço & $\begin{array}{l}\text { Desenvolvimento de } \\
\text { coleções. } \\
\text { Tratamento e organização de } \\
\text { coleções. } \\
\text { Disseminação da informação. } \\
\text { Atendimento ao usuário: } \\
\text { apoio à pesquisa. } \\
\text { Capacitações. }\end{array}$ & $\begin{array}{l}\text { Idem ao difusora de } \\
\text { informação, somado às } \\
\text { novas operações: } \\
\text { Edição de materiais didáticos, } \\
\text { trabalhos acadêmicos, etc. } \\
\text { Gestão de repositórios } \\
\text { institucionais e revistas } \\
\text { eletrônicas. } \\
\text { Gestão de direitos autorais } \\
\text { Gestão de pre-print e pos- } \\
\text { print de produção científica. } \\
\text { Desenvolvimento de } \\
\text { competências informacionais. }\end{array}$ \\
\hline $\begin{array}{c}\text { Inputs: bens, pessoas e } \\
\text { instalações }\end{array}$ & $\begin{array}{l}\text { Bens: manuais de trabalho, } \\
\text { tecnologias voltadas a } \\
\text { informatização e automação, } \\
\text { redes de internet. } \\
\text { Pessoas: funcionários } \\
\text { capacitados para gestão e } \\
\text { tratamento da informação e } \\
\text { pesquisa. } \\
\text { Instalações: Espaços físicos } \\
\text { voltados para o acervo. }\end{array}$ & 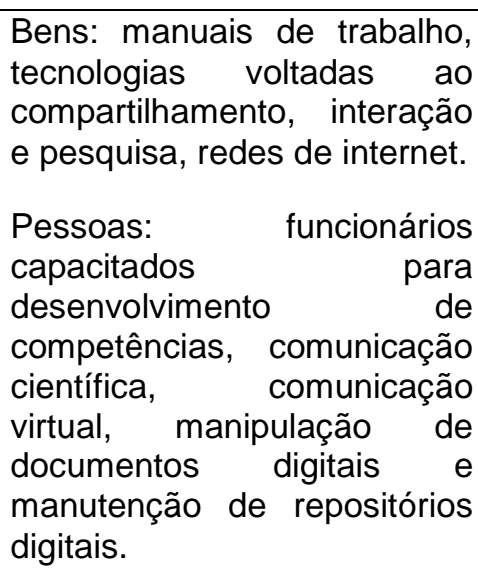 \\
\hline
\end{tabular}




\begin{tabular}{|c|c|c|}
\hline $\begin{array}{l}\text { Elementos-chave do } \\
\text { conceito de serviço }\end{array}$ & Difusora da informação & Produtora de informação \\
\hline & & $\begin{array}{l}\text { Instalações: Espaços físicos } \\
\text { voltados para convivência, } \\
\text { debates, estudo individual e } \\
\text { coletivo. Salas multimídias. }\end{array}$ \\
\hline $\begin{array}{l}\text { Processo de serviço: } \\
\text { experiência do cliente }\end{array}$ & $\begin{array}{l}\text { Relacionamento presencial e } \\
\text { virtual do usuário com o } \\
\text { espaço da biblioteca e } \\
\text { funcionários para encontrar } \\
\text { informação. }\end{array}$ & $\begin{array}{l}\text { Relacionamento presencial } \\
\text { no espaço da biblioteca para } \\
\text { produção de informação. } \\
\text { Relacionamento virtual com } \\
\text { os usuários para orientações } \\
\text { no desenvolvimento e gestão } \\
\text { de materiais acadêmicos } \\
\text { (trabalhos acadêmicos, } \\
\text { artigos, revistas, materiais } \\
\text { didáticos, etc), para o uso de } \\
\text { interfaces digitais (bases de } \\
\text { dados, e-books, etc). }\end{array}$ \\
\hline $\begin{array}{l}\text { Produto do serviço: } \\
\text { resultados }\end{array}$ & Usuário informado. & $\begin{array}{l}\text { Usuário } \\
\text { desenvolvimento informado, } \\
\text { competências e produção de } \\
\text { materiais. }\end{array}$ \\
\hline Valor & $\begin{array}{l}\text { Acesso rápido a informação } \\
\text { fidedigna. }\end{array}$ & $\begin{array}{l}\text { Produção de trabalhos } \mathrm{e} \\
\text { materiais. }\end{array}$ \\
\hline Usuários & $\begin{array}{l}\text { Alunos (graduação e pós- } \\
\text { graduação) e docentes que } \\
\text { necessitam recuperar } \\
\text { informações. Utilizam meios } \\
\text { físicos e digitais para } \\
\text { pesquisar. }\end{array}$ & $\begin{array}{l}\text { Alunos (graduação e pós- } \\
\text { graduação) e docentes que } \\
\text { necessitam de orientações na } \\
\text { análise, organização e } \\
\text { produção de dados. Utilizam } \\
\text { mais meios digitais para } \\
\text { pesquisa e interação. }\end{array}$ \\
\hline
\end{tabular}

Fonte: Bacalgini e Silva $(2015$, p.11)

O quadro indica a relação de conceito de serviço de biblioca com conceitos de gestão de serviço, assim, ao longo desta pesquisa iremos relacionar a necessidade de revisão conceitual de serviço de biblioteca acadêmica para uma adequada gestão de e-books.

Há poucos autores que tratam especificamente de gestão de e-books de forma geral observando como todos os processos irão dialogar e estar estruturados para a produção do serviço de disponibilização de e-books aos usuários, a maioria foca em apenas algumas partes da gestão de e-books como catalogação, indexação, capacitação, etc. Wilkins, (2007) e Walters (2013) tratam do tema de gestão de e-books, porém não desenharam um modelo. Vasileiou, Rowley e Hartley 
(2012a) é que especificamente criaram um modelo de gestão, apresentado na figura 12:

Figura 12 - Modelo de gestão de e-books de Vasileiou, Rowley e Hartley (2012a)

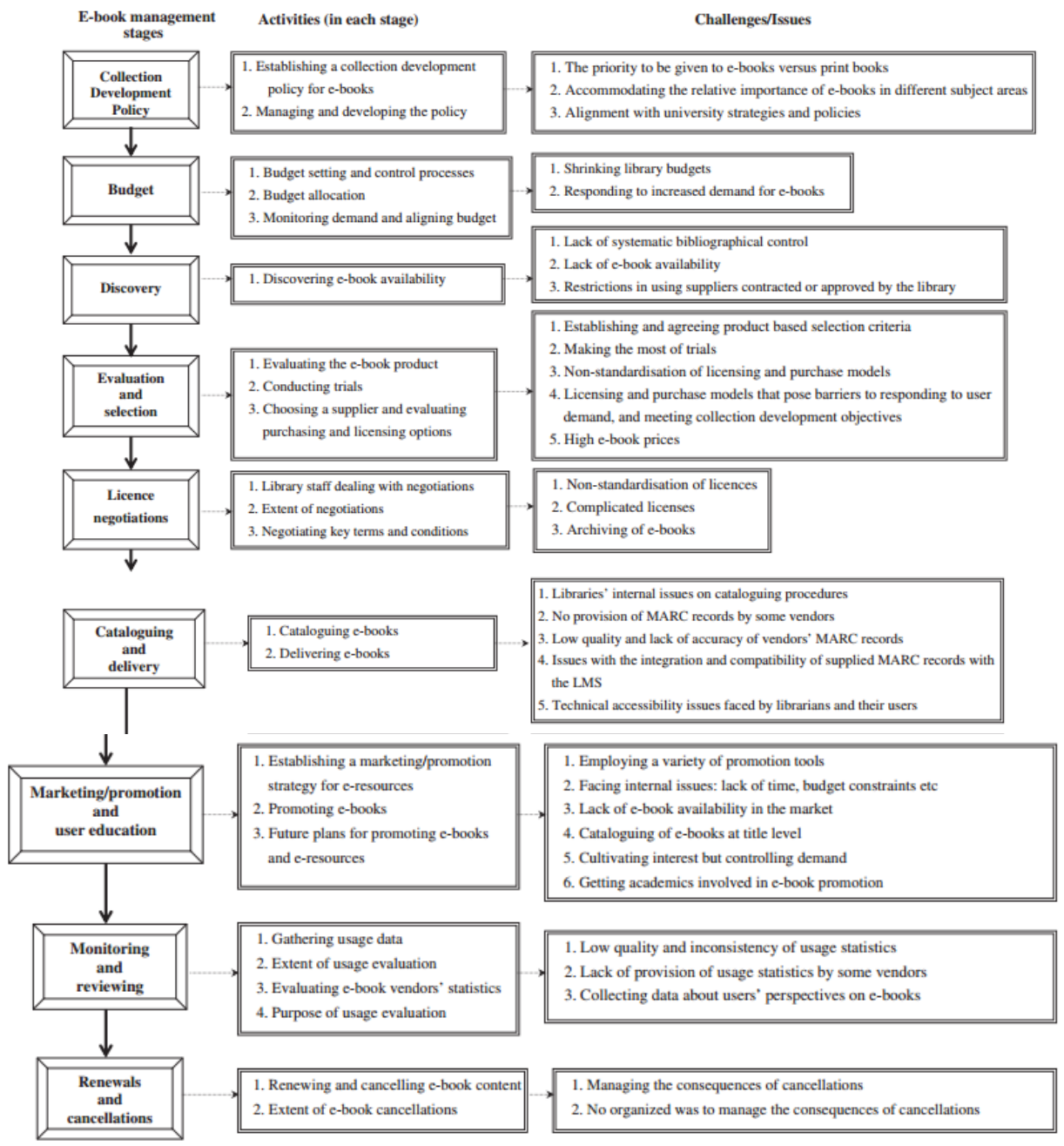

Fig. 1. The e-book management framework.

Fonte: Vasileiou, Rowley e Hartley (2012a, p. 289).

O modelo de gestão de e-books de Vasileiou, Rowley e Hartley (2012a) se aproxima do modo tradicional de gestão de livros impressos em bibliotecas universitárias, demonstrando as dificuldades e desafios para compra, tratamento, divulgação e outras atividades com e-books. Este modelo nos auxilia nesta pesquisa por demonstrar que o e-book é um material com especifidades de gestão diferentes do impresso e apresentar os problemas e desafios de cada etapa, porém Ihe falta a formulação de um fluxo diferente do tradicional impresso que dê atencial especial a questões de aquisição, comerciais, institucionais, legais, capacitação, marketing, etc. 
Como colocam Kingman-Brundage, George e Bowen (1995) a multidisciplinalidade dos serviços dificulta a gestão da produção e a sistematização dos papéis das diferentes partes envolvidas. Para contornar essas dificuldades, é necessário mapear e analisar a gestão de e-books na biblioteca universitária a fim de compreender melhor usuários, funcionários, processos, uso de equipamentos, entre outros, relacionando o modelo de gestão com o conceito de serviço, pois estão entrelaçados. Em outras palavras, o conceito influencia a forma e o desenvolvimento da gestão.

O service blueprinting auxilia a mapear processos na gestão de serviços, baseando-se em diferentes dimensões que se relacionam: cliente/usuário, linha de frente (front office), bastidores (backoffice), suporte e gestão, ressaltando a interação do cliente/usuário com o serviço. Kingman-Brundage, George e Bowen (1995) elaboraram o modelo de mapeamento de produção de serviços segundo o conceito de service blueprinting, o qual utilizamos para apresentar a gestão de e-books pela Unesp e assim poder analisar a relação entre as etapas desta gestão e posteriormente com conceito de serviço de biblioteca. 


\title{
3. PROCEDIMENTOS METODOLÓGICOS
}

\subsection{Apresentação}

Nesta seção iremos definir os procedimentos metodológicos empregados a partir do problema e dos objetivos desta pesquisa. A proposta desta dissertação é analisar a produção do serviço de disponibilização de e-books pelas bibliotecas universitárias a fim de detectar possíveis problemas na gestão de livros eletrônicos que impactam o uso dos e-books. Analisa-se o contexto em que o objetivo de pesquisa se situa e também a perspectiva dos usuários. Desta maneira, a abordagem qualitativa se faz mais pertinente:

\begin{abstract}
A característica distintiva, em contraste com a pesquisa quantitativa, é a ênfase na perspectiva do indivíduo que está sendo estudado. A preocupação é obter informações sobre a perspectiva dos indivíduos, bem como interpretar o ambiente em que a problemática acontece. Isso implica que 0 ambiente natural dos indivíduos é 0 ambiente de pesquisa. (MARTINS, 2012, p. 52).
\end{abstract}

No desdobramento do objetivo geral para os específicos temos:

1. Apresentar o ambiente externo: a rede de produção do livro eletrônico, reconhecendo as pressões externas para redistribuição de processos internos das bibliotecas;

2. Mapear e analisar a produção do serviço de disponibilização de ebooks da aquisição até chegada ao usuário em um estudo de caso, afim de identificar pontos críticos e desafios na gestão de serviços;

3. Relacionar o novo conceito de serviço de biblioteca universitária proposto pela literatura com a gestão de e-books.

Realizou-se revisão de literatura para atender todos objetivos específicos, auxiliando a comprender o contexto da problemática (1) e analisar a pesquisa em campo com base teórica (2, 3 e 4). A fim de organizar as etapas da revisão e seguir um protocolo de pesquisa, utilizou-se o modelo de Perkmann et al. (2013), o qual estabelece passos que auxiliam a encontrar em análise retrospectiva e atual publicações acadêmicas focadas no objetivo de pesquisa. Por fim, elaboramos um glossário, a fim de facilitar a compreensão e leitura da dissertação. Apresentamos a 
metodologia de Perkmann et al. (2013) e como a utilizamos na dissertação no quadro 5:

Quadro 5: Aplicação da metodologia de Perkmann et al. (2013)

\begin{tabular}{|c|c|}
\hline $\begin{array}{l}\text { Protocolo de pesquisa de Perkmann et } \\
\text { al. (2013) }\end{array}$ & Aplicação na dissertação \\
\hline $\begin{array}{c}\text { Identificar a produção científica durante um } \\
\text { determinado período. }\end{array}$ & $\begin{array}{l}\text { Adotamos como base a revisão de artigos de } \\
1990 \text { a } 2015 \text { sobre bibliotecas universitárias, } \\
\text { e-books e mudanças tecnológicas. } \\
\text { Estabelecemos a data de partir de 1990, pois } \\
\text { marca a expansão e popularização da } \\
\text { internet e das TICs. }\end{array}$ \\
\hline $\begin{array}{l}\text { Realizar busca em bases de dados científicas } \\
\text { utilizando palavras-chaves da literatura. }\end{array}$ & 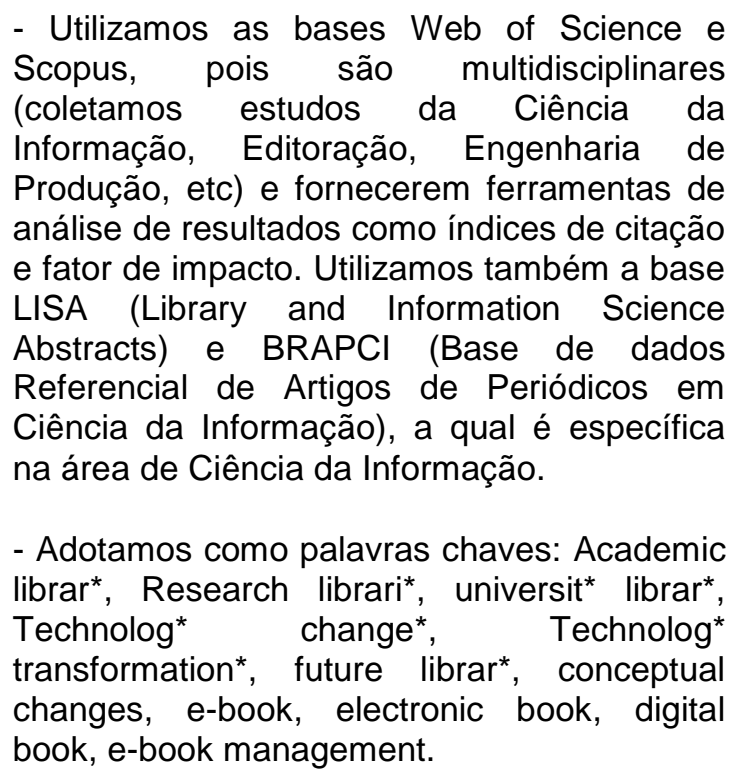 \\
\hline $\begin{array}{l}\text { Refinar a busca em periódicos com maior } \\
\text { índice de citação e avaliação. }\end{array}$ & $\begin{array}{c}\text { Selecionamos revistas com base no Journal } \\
\text { Citations Reports e no Qualis Periódicos } \\
\text { CAPES. }\end{array}$ \\
\hline $\begin{array}{l}\text { Refinar a busca na área de pesquisa de } \\
\text { interesse. }\end{array}$ & $\begin{array}{l}\text { Selecionamos artigos que abordavam gestão } \\
\text { de e-books, questões conceituais de serviços } \\
\text { de bibliotecas, mercado editorial e impactos e } \\
\text { desafios dos e-books às bibliotecas } \\
\text { universitárias. }\end{array}$ \\
\hline $\begin{array}{l}\text { Seleção qualitativa de artigos que } \\
\text { apresentavam metodologia acurada e } \\
\text { resultados claros e embasados. }\end{array}$ & Foram selecionados 47 estudos. \\
\hline $\begin{array}{l}\text { Apresentação esquemática dos artigos } \\
\text { selecionados em pergunta de pesquisa, } \\
\text { abordagem, método e resultados. }\end{array}$ & Conferir Apêndice A. \\
\hline
\end{tabular}


Na pesquisa em campo utilizamos estudo de caso, pois este método permite maior aproximação com os sujeitos envolvidos e coleta de dados no contexto em que ocorre o fenômeno (GIL, 2008; MIGUEL, 2010; YIN, 2010).

Adotamos um estudo de caso único: uma rede de 32 bibliotecas universitárias distribuídas em 24 cidades do Estado de São Paulo de uma universidade pública - a Unesp. A escolha pela Unesp se deve ao fato que esta universidade é constituída por uma das maiores redes de bibliotecas universitárias do Brasil com assinatura de recursos digitais, além disso, a pesquisadora é funcionária da universidade, facilitando o acesso aos dados para pesquisa de campo.

Apesar da Unesp possuir bibliotecas com usuários de perfis e áreas do conhecimento diferentes, situadas em locais geográficos distintos, entendemos ser um único caso, pois todas as bibliotecas seguem as diretrizes da universidade e dos campi que estão subordinadas e a maioria de suas atividades é desenvolvida de acordo com padrões estabelecidos por um órgão central que coordena tecnicamente todas as bibliotecas, chamado Coordenadoria Geral de Bibliotecas (CGB).

O estudo de caso único tem a desvantagem de não permitir generalizações e elaboração de teorias, além de constar menor número de observações de diferentes contextos, aumentando o risco de maior viés pela interpretação do pesquisador. Contudo, o estudo de caso único permite maior aprofundamento e comparação mais detalhada de diferentes pontos de vista no caso (EISENHARDT, 1989; VOSS; TSIKRITSIS; FROHLICH, 2002; YIN, 2010).

Mesmo sendo um caso único, entendemos, que a Unesp é um caso representativo e que algumas análises a serem realizadas podem ser aplicadas em outras universidades públicas estaduais, pois contempla assinatura de bases de dados semelhantes com à Universidade de São Paulo (USP) e à Universidade Estadual de Campinas (Unicamp) e possui estrutura de assinatura de recursos eletrônicos centralizada de forma similar a outras universidades públicas (BACALGINI; SILVA, 2013).

No início desta pesquisa foi realizada revisão de literatura sobre e-books, bibliotecas universitárias, mudanças nas bibliotecas, novos conceitos de biblioteca e gestão de serviços. Posteriormente, realizamos uma aproximação de campo com entrevistas semiestruturadas. Os resultados da pesquisa em campo serão apresentados no tópico 4 - Resultados e analisados a partir da literatura no tópico 5 - Discussão. 


\subsection{Estudo de caso}

A Unesp foi fundada em 1976 com a junção de institutos isolados de ensino superior que existiam em diversas regiões do Estado de São Paulo. Possui 37.888 alunos de graduação distribuídos em 134 cursos e 13.206 alunos de pós-graduação em 141 programas de pós-graduação. Conta com 3.880 professores e 7.071 funcionários, os quais trabalham entre as 34 faculdades e institutos da Unesp distribuídas em 24 cidades do Estado de São Paulo (UNESP, 2015a).

A Unesp dispõe de 32 bibliotecas, as quais abrigam mais de 3,3 milhões de documentos, compondo uma Rede de Bibliotecas. Esta Rede é gerida tecnicamente pela Coordenadoria Geral de Bibliotecas (CGB), que coloca diretrizes, políticas, normas e procedimentos técnicos para todas as bibliotecas seguirem. A CGB procura criar condições para o "funcionamento sistêmico" das bibliotecas de todos os campi da Unesp (UNESP, 2015b). A CGB possui desde 1991 escritórios em Marília e na Reitoria em São Paulo, sendo estruturada em dois grupos: Grupo de Organização e Recuperação da Informação, responsável pela "[...] administração, manutenção, capacitação e suporte das atividades relacionadas a automação nas Bibliotecas da Rede [...]" e o Grupo de Gestão de Recursos da Informação:

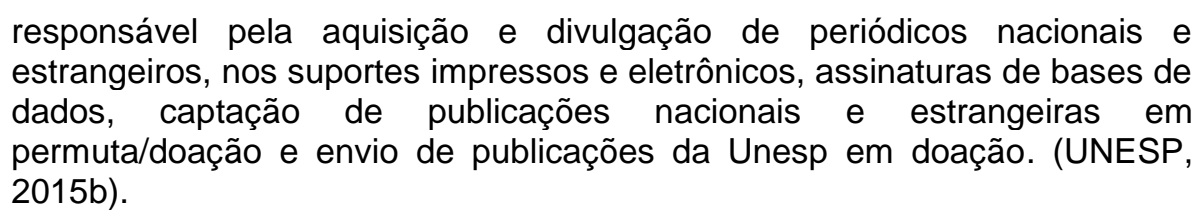

Segundo o site da Coordenadoria Geral de Bibliotecas da Unesp, a Rede de Bibliotecas da Unesp tem como missão:

\footnotetext{
"Propiciar uma efetiva interação entre as bibliotecas que compõem a Rede de Bibliotecas da Unesp, o meio acadêmico e instituições congêneres nacionais e internacionais, através de ações conjuntas, facilitando a comunicação entre os vários segmentos da Universidade, visando à democratização da informação em benefício da sociedade" (UNESP, 2015b).
} 
Sendo as atribuições da Rede:

- $\quad$ "Coordenar o desenvolvimento das atividades da Rede de Bibliotecas da Universidade, criando condições para seu funcionamento sistêmico, mediante assessoramento do Fórum Deliberativo dos Diretores das Divisões/Serviços Técnicos/Bibliotecas e Coordenação;

- Propor diretrizes, políticas, programas e projetos de informação, visando à melhoria das atividades acadêmicas, científicas, culturais, artísticas e administrativas no âmbito da Unesp;

- Estabelecer normas e procedimentos técnicos para a Rede de Bibliotecas;

- Propiciar condições adequadas, por meio de infra-estrutura tecnológica, visando ao gerenciamento da informação de qualidade;

- Propiciar condições adequadas, por meio da educação continuada, visando à eficiência dos serviços e produtos informacionais disponibilizados no âmbito da Unesp;

- Apoiar as políticas, programas e projetos desenvolvidos na Universidade, proporcionando colaboração técnica por meio da Rede de Bibliotecas" (UNESP, 2015b).

A assinatura de bases de dados na Unesp é centralizada, ou seja, as bibliotecas que compõem a Rede de Bibliotecas apenas indicam títulos e não realizam o processo de aquisição.

Já em relação à estrutura das bibliotecas da Unesp, a Portaria da Unesp no 469 de 25 de julho de 2012 regulamenta as atribuições das unidades administrativas da Unesp: as bibliotecas de Câmpus/Unidades consolidadas são identificadas como Serviço Técnico de Biblioteca e Documentação, o qual é dividido em duas seções técnicas: Seção Técnica de Referência, Atendimento ao Usuário e Documentação e Seção Técnica de Aquisição e Tratamento da Informação. O Serviço Técnico é subordinado à Direção do Câmpus no caso de unidades consolidadas, no caso de campi Experimentais a biblioteca não é caracterizada como Serviço Técnico e sim como uma Área (não tendo as duas seções técnicas), a qual é Subordinada à Seção Técnica de Apoio Acadêmico, que por sua vez, é subordinada à Coordenação Executiva do Câmpus (posição semelhante a Direção de um câmpus consolidado). A figura 13 aponta a estrutura das bibliotecas da Unesp em câmpus consolidado e Experimental: 
Figura 13 - Estrutura organizacional

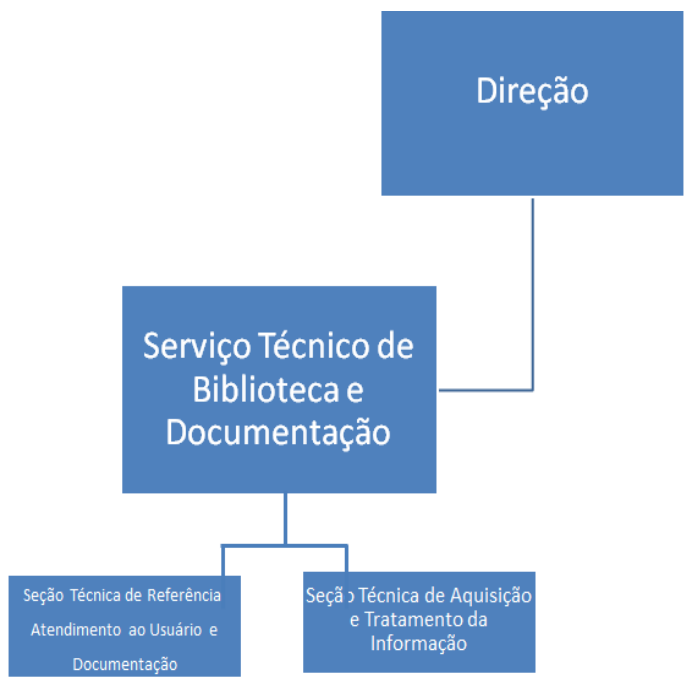

Câmpus consolidado

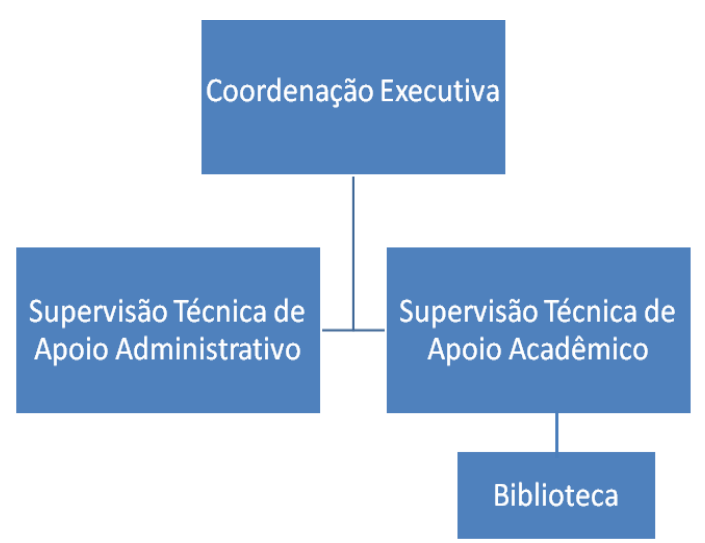

Câmpus Experimental

Fonte: Autoria própria.

As atividades desempenhadas pelas bibliotecas de Câmpus consolidado, segundo a Portaria da Unesp no 469/2012, são apresentadas no quadro 6: 
Quadro 6 - Atividades desempenhadas pelas bibliotecas da Unesp

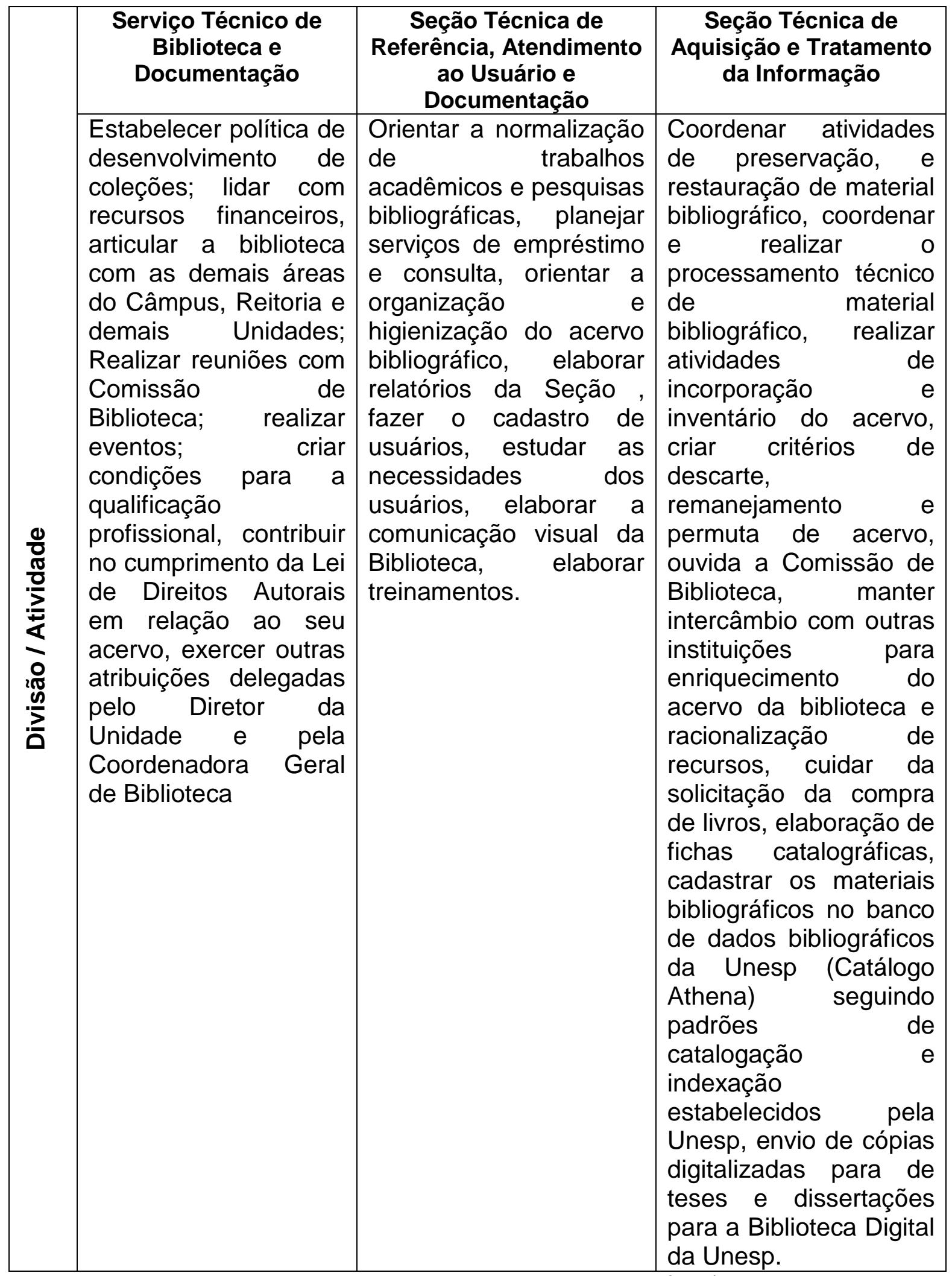

Fonte: Adaptação e resumo da Portaria da Unesp no469/2012. 
Os usuários da Rede de Bibliotecas podem ser internos ou externos: os usuários externos são os que não possuem vínculo com a universidade e podem realizar consultas locais nos acervos das bibliotecas; estes usuários não estão contemplados nesta pesquisa. Os usuários internos são alunos (graduação e pósgraduação), docentes e funcionários da universidade.

\subsection{Entrevistas}

Durante o mês de Agosto foram entrevistados 8 diretores da Rede de Bibliotecas da Unesp e da Coordenadoria Geral de Bibliotecas, na figura de sua Coordenadora e de 3 bibliotecárias da CGB responsáveis pelo processo de aquisição e armazenamento de e-books. Todos os entrevistados são formados em Biblioteconomia com idade variando entre 25 a 65 anos.

As entrevistas semiestruturadas foram conduzidas por um roteiro estruturado, elaborado pela pesquisadora com base no referencial teórico de gestão de e-books de Wilkins (2007), Procópio (2010), Oliveira (2012), Vasileiou, Rowley e Hartley (2012a) e Walters (2013), representado no quadro 7: 
Quadro 7 - Roteiro para entrevistas semiestruturadas

\begin{tabular}{|c|c|c|c|c|}
\hline $\begin{array}{l}\text { Etapas da } \\
\text { gestão }\end{array}$ & \multicolumn{2}{|c|}{ Questões encontradas na literatura } & \multirow{2}{*}{$\begin{array}{c}\text { Resultados da literatura } \\
\text { Assinatura } \\
\end{array}$} & \multirow{2}{*}{ Entrevistado } \\
\hline \multirow{15}{*}{ Aquisição } & \multirow{15}{*}{$\begin{array}{l}\text { Modelos de } \\
\text { negócio }\end{array}$} & \multirow{6}{*}{$\begin{array}{l}\text { Quais são os modelos de } \\
\text { negócio adotados? }\end{array}$} & & \\
\hline & & & Acesso perpétuo & \multirow{11}{*}{ CGB } \\
\hline & & & Patron Driven Acquisition & \\
\hline & & & Aluguel & \\
\hline & & & Empréstimo virtual ou STL & \\
\hline & & & Pay per view & \\
\hline & & $\begin{array}{c}\text { A biblioteca conhece } \\
\text { todos os modelos de } \\
\text { negócio existentes no } \\
\text { mercado? }\end{array}$ & Desconhecimento de modelos de negócio & \\
\hline & & \multirow{5}{*}{$\begin{array}{c}\text { Quais critérios que a } \\
\text { biblioteca utiliza para } \\
\text { escolher o(s) modelo(s) } \\
\text { de negócio que irá } \\
\text { adotar? }\end{array}$} & Relação custo x benefício & \\
\hline & & & Restrições legais & \\
\hline & & & Restrições institucionais & \\
\hline & & & $\begin{array}{l}\text { Existência de taxas de manutenção da } \\
\text { plataforma em que o e-book está hospedado }\end{array}$ & \\
\hline & & & $\begin{array}{l}\text { Formas de acessar o e-book que o modelo de } \\
\text { negócio permite }\end{array}$ & \\
\hline & & $\begin{array}{l}\text { Diversidade de modelos } \\
\text { de negócio }\end{array}$ & $\begin{array}{l}\text { Como gerir cada modelo de negócio? Ao } \\
\text { contrário dos livros impressos em que todos } \\
\text { os dados de aquisição e exclusão podem ser } \\
\text { cadastrados em um software gerenciador de } \\
\text { acervo usado pela biblioteca, com ebooks o } \\
\text { gerenciamento da coleção é muitas vezes na } \\
\text { plataforma do fornecedor }\end{array}$ & \multirow[t]{3}{*}{ CGB } \\
\hline & & \multirow[b]{2}{*}{$\begin{array}{c}\text { Negociação com editores: } \\
\text { como a biblioteca negocia } \\
\text { com editores? }\end{array}$} & Consórcios & \\
\hline & & & $\begin{array}{l}\text { Solicitação de descontos em plataformas que } \\
\text { cobram taxas de manutenção }\end{array}$ & \\
\hline
\end{tabular}


Quadro 7 - Roteiro para entrevistas semiestruturadas

\begin{tabular}{|c|c|c|c|c|}
\hline $\begin{array}{l}\text { Etapas da } \\
\text { gestão }\end{array}$ & \multicolumn{2}{|c|}{ Questões encontradas na literatura } & Resultados da literatura & Entrevistado \\
\hline \multirow{18}{*}{ Aquisição } & \multirow{14}{*}{ Seleção } & \multirow{10}{*}{$\begin{array}{l}\text { Quais os critérios de } \\
\text { seleção de uma base de } \\
\text { dados de e-books }\end{array}$} & Atualidade da coleção de títulos de ebooks & \multirow{18}{*}{ CGB } \\
\hline & & & Relevância da coleção para os usuários & \\
\hline & & & Cobertura temática da coleção & \\
\hline & & & $\begin{array}{c}\text { Recomendações de professores e } \\
\text { especialistas }\end{array}$ & \\
\hline & & & Demanda de usuários & \\
\hline & & & Preço & \\
\hline & & & Tipo de licença para acesso aos ebooks & \\
\hline & & & Usabilidade da base de dados & \\
\hline & & & $\begin{array}{l}\text { Possibilidade de integração da coleção de } \\
\text { ebooks com o catálogo da biblioteca }\end{array}$ & \\
\hline & & & $\begin{array}{l}\text { Fornecimento de metadados para adicionar } \\
\text { registros de catalogação no sistema da } \\
\text { biblioteca }\end{array}$ & \\
\hline & & \multirow{4}{*}{$\begin{array}{l}\text { Como descobrir novos } \\
\text { títulos de ebooks? }\end{array}$} & Via usuários & \\
\hline & & & Via listas de discussão & \\
\hline & & & Via alertas do fornecedor da base de dados & \\
\hline & & & Via trials & \\
\hline & \begin{tabular}{|c|} 
Política de \\
desenvolvimento \\
de coleções de \\
ebooks \\
\end{tabular} & Existe? & $\begin{array}{l}\text { Estão formalizados os critérios de seleção de } \\
\text { modelos de negócio, de bases de dados, de } \\
\text { avaliação da coleção, de exclusão de ebooks? }\end{array}$ & \\
\hline & \multirow{3}{*}{$\begin{array}{l}\text { Monitoramento e } \\
\text { avaliação da } \\
\text { coleção }\end{array}$} & \multirow{3}{*}{$\begin{array}{l}\text { Quais os critérios para } \\
\text { exclusão, cancelamento } \\
\text { de assinaturas e } \\
\text { renovação da coleção? }\end{array}$} & $\begin{array}{c}\text { Análise de estatísticas } \\
\text { (observar se há problemas na geração de } \\
\text { estatísticas) }\end{array}$ & \\
\hline & & & Estudo de satisfação do usuário & \\
\hline & & & $\begin{array}{l}\text { Fornecedor alerta sobre a retirada de títulos } \\
\text { da coleção? }\end{array}$ & \\
\hline
\end{tabular}


Quadro 7 - Roteiro para entrevistas semiestruturadas

\begin{tabular}{|c|c|c|c|c|}
\hline $\begin{array}{l}\text { Etapas da } \\
\text { gestão }\end{array}$ & \multicolumn{2}{|c|}{ Questões encontradas na literatura } & Resultados da literatura & Entrevistado \\
\hline \multirow[b]{3}{*}{ Armazenamento } & \multicolumn{2}{|c|}{ Garantir autenticidade do documento } & \multirow[b]{3}{*}{$\begin{array}{l}\text { Fornecedor/editor tem parceria com } \\
\text { instituições ou participa de projetos que } \\
\text { garantam o acesso ao ebook íntegro mesmo } \\
\text { que o fornecedor/editor entre em falência? }\end{array}$} & \multirow[b]{3}{*}{ CGB } \\
\hline & \multicolumn{2}{|c|}{ Preservação digital } & & \\
\hline & $\begin{array}{l}\text { Qual servidor o } \\
\text { e-book será } \\
\text { alocado? }\end{array}$ & $\begin{array}{l}\text { No da biblioteca ou no } \\
\text { do editor/fornecedor? }\end{array}$ & & \\
\hline \multirow{12}{*}{$\begin{array}{l}\text { Acesso: como o } \\
\text { usuário } \\
\text { consegue } \\
\text { acessar/ler o e- } \\
\text { book? }\end{array}$} & \multirow{9}{*}{\multicolumn{2}{|c|}{$\begin{array}{c}\text { Fatores que afetam o acesso do usuário ao } \\
\text { ebook }\end{array}$}} & $\begin{array}{l}\text { Variedade de formatos/dispositivos: problema } \\
\text { ou vantagem }\end{array}$ & \multirow{12}{*}{ DIRETOR DE BIBLIOTECA } \\
\hline & & & Disponibilidade de títulos em ebook & \\
\hline & & & Idioma acessível & \\
\hline & & & Download? Livro inteiro, capítulos ou negado & \\
\hline & & & Acesso simultâneo & \\
\hline & & & Empréstimo virtual & \\
\hline & & & Acesso off-line? & \\
\hline & & & Permite impressão? & \\
\hline & & & Usabilidade da base de dados & \\
\hline & \multirow{3}{*}{$\begin{array}{l}\text { Gestão das } \\
\text { regras de acesso }\end{array}$} & \multirow{3}{*}{$\begin{array}{l}\text { Diversidade de formas } \\
\text { de acesso e restrição } \\
\quad \text { entre os } \\
\text { editores/fornecedores }\end{array}$} & Como gerir esta diversidade? & \\
\hline & & & & \\
\hline & & & $\begin{array}{l}\text { Como informar/explicar ao usuário a } \\
\text { diversidade de formas de acesso? }\end{array}$ & \\
\hline \multirow{3}{*}{$\begin{array}{l}\text { Busca: como o } \\
\text { usuário } \\
\text { consegue } \\
\text { encontrar o e- } \\
\text { book? }\end{array}$} & \multicolumn{2}{|c|}{ Usuário sabe onde encontrar? } & Divulgação de ferramentas para busca & \multirow{3}{*}{ DIRETOR DE BIBLIOTECA } \\
\hline & \multirow{2}{*}{$\begin{array}{l}\text { Usuário sabe } \\
\text { buscar? }\end{array}$} & \multirow{2}{*}{$\begin{array}{l}\text { Fatores que influenciam } \\
\text { na busca }\end{array}$} & Filtros de pesquisa da base de dados & \\
\hline & & & Usabilidade da base de dados & \\
\hline
\end{tabular}


Quadro 7 - Roteiro para entrevistas semiestruturadas

\begin{tabular}{|c|c|c|c|c|}
\hline $\begin{array}{l}\text { Etapas da } \\
\text { gestão }\end{array}$ & \multicolumn{2}{|c|}{ Questões encontradas na literatura } & Resultados da literatura & Entrevistado \\
\hline \multirow{9}{*}{ Capacitação } & \multirow{6}{*}{ Funcionários } & \multirow{6}{*}{$\begin{array}{l}\text { Quais conhecimentos } \\
\text { necessitam ser } \\
\text { desenvolvidos em } \\
\text { funcionários? }\end{array}$} & Modelos de negócio & \multirow{9}{*}{ DIRETOR DE BIBLIOTECA } \\
\hline & & & $\begin{array}{c}\text { Questões legais sobre a aquisição, exclusão, } \\
\text { cancelamento e renovaçãa de bases de } \\
\text { dados }\end{array}$ & \\
\hline & & & Direitos autorais & \\
\hline & & & Mercado editorial & \\
\hline & & & Uso das bases de dados de ebooks & \\
\hline & & & Uso de dispositivos de leituras de ebooks & \\
\hline & \multirow[t]{3}{*}{ Usuários } & \multirow{3}{*}{$\begin{array}{c}\text { Quais conhecimentos } \\
\text { necessitam ser } \\
\text { desenvolvidos em } \\
\text { usuários? }\end{array}$} & Buscar ebooks & \\
\hline & & & Acessar ebooks & \\
\hline & & & Uso de dispositivos de leituras de ebooks & \\
\hline \multirow{6}{*}{$\begin{array}{l}\text { Divulgação/ } \\
\text { Marketing }\end{array}$} & \multicolumn{2}{|c|}{ Quais são os canais de divulgação? } & $\begin{array}{l}\text { Mural, redes sociais, sites, folhetos, emails e } \\
\text { capacitações }\end{array}$ & \multirow{6}{*}{ DIRETOR DE BIBLIOTECA } \\
\hline & \multirow{2}{*}{\multicolumn{2}{|c|}{$\begin{array}{l}\text { O que é divulgado nas ações de marketing } \\
\text { da biblioteca? }\end{array}$}} & Que coleções de ebooks existe & \\
\hline & & & Como buscar e acessar ebooks & \\
\hline & Qual a freq & cia de divulgação? & Poucos divulgam periodicamente & \\
\hline & $\begin{array}{r}\text { A divulgaçã } \\
\text { difer }\end{array}$ & $\begin{array}{l}\text { personalizada para } \\
\text { es públicos? }\end{array}$ & $\begin{array}{l}\text { Professores, alunos (graduação e pós- } \\
\text { graduação), intercambistas e funcionários }\end{array}$ & \\
\hline & \multicolumn{2}{|c|}{$\begin{array}{c}\text { Existe estratégia de marketing coletiva } \\
\text { entre as bibliotecas ? Ou iniciativas } \\
\text { isoladas? }\end{array}$} & Não & \\
\hline \multirow{2}{*}{$\begin{array}{l}\text { Tratamento da } \\
\text { informação }\end{array}$} & \multirow{2}{*}{\multicolumn{2}{|c|}{$\begin{array}{l}\text { Houve mudança nas atividades } \\
\text { processamento técnico com os ebooks? }\end{array}$}} & Regras de Catalogação & \multirow{2}{*}{ DIRETOR DE BIBLIOTECA } \\
\hline & & & $\begin{array}{l}\text { Metadados de descrição de dados de } \\
\text { catalogação }\end{array}$ & \\
\hline
\end{tabular}


Quadro 7 - Roteiro para entrevistas semiestruturadas

\begin{tabular}{|c|c|c|c|}
\hline $\begin{array}{l}\text { Etapas da } \\
\text { gestão }\end{array}$ & Questões encontradas na literatura & Resultados da literatura & Entrevistado \\
\hline \multirow{5}{*}{$\begin{array}{l}\text { Organização do } \\
\text { trabalho }\end{array}$} & $\begin{array}{l}\text { Novos processos de trabalho foram } \\
\text { incorporados? Ou processos antigos } \\
\text { foram modificados? }\end{array}$ & $\begin{array}{l}\text { Principalmente em atividades de organização } \\
\text { e capacitaçao }\end{array}$ & \multirow{5}{*}{ DIRETOR DE BIBLIOTECA } \\
\hline & $\begin{array}{l}\text { As etapas de gestão de ebooks são } \\
\text { seguidas / formalizadas na biblioteca? }\end{array}$ & Geralmente não & \\
\hline & $\begin{array}{l}\text { Dificuldades em incorporar novos } \\
\text { processos de trabalho? }\end{array}$ & $\begin{array}{l}\text { Número reduzido de funcionários, excesso de } \\
\text { atividades, atividades que poderiam ser } \\
\text { simplificadas ou que são ultrapassadas }\end{array}$ & \\
\hline & $\begin{array}{l}\text { Comunicação entre diferentes } \\
\text { departamentos da biblioteca }\end{array}$ & Por vezes burocrático ou lento & \\
\hline & $\begin{array}{l}\text { Novo perfil de equipe de trabalho da } \\
\text { biblioteca }\end{array}$ & $\begin{array}{l}\text { Há presença de profissionais de outras áreas } \\
\text { auxiliando na gestão de ebooks em alguma } \\
\text { etapa descrita? Direito, mercado editorial, } \\
\text { tecnologia da informação? }\end{array}$ & \\
\hline
\end{tabular}

Fonte: autoria própria. 
A escolha por entrevista semiestruturada foi para apreender diferentes pontos de vista e compreender o contexto (MARTINS, 2012) sobre as etapas da gestão de e-books proposta na literatura, desta forma, podemos verificar se há problemas ou lacunas na gestão na Unesp.

Como nosso foco é analisar a gestão da biblioteca para a produção do serviço de disponibilização de e-book, não era o intuito da pesquisa se aprofundar em questões técnicas de tratamento da informação, de competência informacional, capacitação, bases de dados, entre outros produtos, serviços e atividades desempenhados pelas bibliotecas acadêmicas, pois o objetivo é observar como a biblioteca se organiza para produzir um serviço, como seus processos estão estruturados e relacionados para culminar na produção do serviço. Desta maneira, foram escolhidos diretores de biblioteca para a entrevista, pois possuem a visão global e gerencial da biblioteca.

Como a assinatura e aquisição de bases de dados de diversos tipos de documentos digitais, incluindo e-books, é centralizada na Coordenadoria Geral de Bibliotecas, foram entrevistadas a Coordenadora da CGB e três bibliotecárias responsáveis pelas etapas na gestão de e-books de aquisição/assinatura e armazenamento. Desta maneira, foi desenvolvido um roteiro de entrevista para diretores de biblioteca e outro para a CGB.

Em relação aos diretores de Biblioteca, foram escolhidos por área do conhecimento e por tamanho da biblioteca (bibliotecas de unidades consolidadas e unidades experimentais).

Procuramos coletar dados estatísticos de uso de base de dados de e-books como número de downloads, número de acessos, número de buscas e quantidade de usuários, porém tivemos dificuldade de acesso a dados que a CGB não consegue gerar, a qual precisa solicitar aos editores/distribuidores/agregadores. Alguns destes fornecedores não nos enviaram, mesmo com cobranças não houve retorno (em um período de 6 meses); outros nos enviaram, porém não conseguimos compreender a terminologia usada para designar os números, e ao entrar em contato para tirar dúvidas não obtivemos retorno. Outras empresas não enviam números como quantidade de usuários por câmpus ou por categoria (graduação, pós-graduação, docente), outros não geram dados de número de acessos, apenas download. Assim, devido à dificuldade de obter os dados, de compreendê-los e de compará-los entre os editores/distribuidores/agregadores, optamos por não utilizá- 
los nesta pesquisa, pois não conseguiríamos desenvolver análises fundamentadas.

Com as entrevistas rastreamos o processo e a gestão de e-books existente na Unesp, porém a universidade não possui um modelo formalizado de gestão. Desta maneira utilizamos as etapas de gestão abordadas na literatura (GARROD, 2004; OLIVEIRA, 2012; PROCÓPIO, 2010; VASILEIOU; ROWLEY; HARTLEY, 2012a; WALTERS, 2013; WILKINS, 2007) como base para descrever o processo de gestão na Unesp e utilizamos o conceito de service blueprinting para descrever o relacionamento destas etapas na gestão. O conceito de service blueprinting foi adotado pois elucida o relacionamento de atividades front office e backoffice, mostrando a importância de atividades internas para a produção do resultado final do serviço, além de evidenciar a relação de departamentos diferentes com a biblioteca e coloca a figura do usuário em destaque, incentivando a produção do serviço voltada ao usuário (BITNER; OSTROM; MORGAN, 2007). 


\section{RESULTADOS: dados coletados}

\subsection{Entrevistados: CGB - etapas de aquisição e armazenamento}

A CGB é responsável pela aquisição e assinatura de base de dados de ebooks da Rede de Bibliotecas da Unesp, além disso, trata de questões contratuais de armazenamento de e-books. As bibliotecas dos campi não participam destes processos.

Dentre os modelos de negócio praticados no mercado de e-books, a Unesp trabalha com dois: assinatura e acesso perpétuo. Outros modelos de negócio não são adotados devido a restrições institucionais, como PDA e Pay-Per-View, os quais geralmente aceitam como pagamento cartão de crédito internacional corporativo, o qual não é utilizado na universidade.

Dentre os critérios para adoção de modelos de negócio, a demanda da comunidade acadêmica é o critério com maior peso adotado pela CGB, se o usuário precisa de um conteúdo, faz-se o possível para adquiri-lo dentro do orçamento disponível. A relação custo $x$ benefício é um critério também, procura-se otimizar os recursos financeiros de acordo com as necessidades dos usuários das bibliotecas. Contudo, há outros fatores que a CGB precisa atender e que é considerado um critério para seleção: restrições legais e institucionais: já ocorreram situações que atrasaram ou impediram a CGB de assinar/adquirir e-books, como por exemplo:

- Todos os distribuidores/agregadores/editoras internacionais trabalham com um modelo de contrato chamado agreement, o qual possui regras de acordo com a legislação em vigor do país em que o editor/agregador/distribuidor está instalado. As condições do agreement tem que estar de acordo com o aval da Assessoria Jurídica da Unesp;

- É necessário cumprir os prazos administrativos da Unesp. Este fato pode ser um obstáculo no momento da renovação de assinaturas, pois nem sempre o processo administrativo para renovação finaliza em tempo hábil antes que se esgote a validade da assinatura, deixando a comunidade sem acesso aos e-books da base; 
- Algumas editoras trabalham com plataformas de empresas terceiras, gerando subcontratos, os quais não são reconhecidos pela Unesp, assim, precisou-se buscar outras soluções para finalizar o negócio com a editora e atender aos requisitos da universidade.

A CGB antes de assinar qualquer contrato sempre recorre à Assessoria Jurídica da Unesp para se resguardar, pois os contratos possuem diversas minúcias, detalhes e consequências legais no descumprimento. Não havendo qualquer objeção por parte da Assessoria Jurídica e se houver disponibilidade orçamentária, o maior critério de escolha é a comunidade acadêmica, sempre será a necessidade do usuário que definirá o que será adquirido, segundo a CGB.

Ressalta-se que muitos títulos de e-books são trabalhados por apenas um editor, distribuidor ou agregador (empresa que representa várias editoras), de modo que a falta de concorrência dificulta a negociação de preços e restrições. Assim mesmo que a forma de acesso ou a existência de taxas de manutenção de plataforma não esteja de acordo com os interesses da CGB, como o e-book só está disponível na base de apenas um editor, distribuidor ou agregador, não há opção de escolha e a CGB acaba aceitando as condições da empresa, pois o usuário de alguma maneira precisa acessar o título de e-book. Por falta de concorrência, o editor, distribuidor ou agregador consegue adotar somente o modelo de negócio e a forma de acesso que deseja.

Já ocorreram situações em que quando as estatísticas apontavam baixo uso, a CGB conseguiu abaixar o preço de assinatura, porém nem sempre os editores, distribuidores ou agregadores se colocam à disposição para renegociar. Mesmo sendo uma das três maiores universidades públicas do Estado de São Paulo junto com a USP e a Unicamp, a Unesp sozinha tem pouco poder de negociação frente a alguns editores, distribuidores ou agregadores. Estes não possuem interesse em mudar restrições contratuais ou preços, pois possuem outros clientes (faculdades particulares) que em sua maioria aceitam e pagam sem discussão, assim, seu mercado é garantido por outros clientes, apenas quando há a junção de USP, Unesp e Unicamp que há chance de negociação, ou seja, a prática de negociação via consórcios é uma das poucas maneiras que a Unesp consegue discutir com editores/fornecedores. 
A CGB também destacou que para a seleção do conteúdo das bases de ebooks o critério de maior peso é a demanda da comunidade acadêmica, representada pelas sugestões de docentes, especialistas (Pró-Reitorias, Coordenadores de Cursos de Pós-Graduação, etc), alunos, bibliotecários, além de estatísticas de uso de livros impressos (procura-se ter a versão em e-book de impressos muito utilizados). A atualidade da coleção de e-books é considerada também no momento da seleção, a CGB indicou que prefere trabalhar com assinatura de bases do que compra perpétua de e-books, pois com as assinaturas se consegue manter títulos mais atuais ao contrário de compra perpétua em que permanecem as edições antigas, sendo necessário fazer nova aquisição para acessar uma edição mais atual. Já na assinatura, no momento da renovação já se opta pelos títulos com edição mais nova, economizando custos.

A questão de preço, usabilidade da base e fornecimento de metadados para agregar a ferramenta de busca integrada da Unesp nem sempre é um critério a ser adotado, pois conforme dito, como alguns títulos são comercializados por apenas uma empresa e a comunidade acadêmica necessita do conteúdo, se não houver oportunidades de negociação ou personalização de interfaces, a CGB irá assinar/adquirir mesmo assim devido a necessidade de acesso ao conteúdo.

A diversidade de modelos de negócio, editores, distribuidores ou agregadores e as diferentes formas de acesso ao e-book são gerenciadas manualmente em planilhas Excel pelos bibliotecários da CGB. A Coordenadora ressaltou que o módulo de aquisição da ferramenta para gestão de acervos que atualmente a Unesp utiliza tem foco em impressos, neste sentido, já se buscaram softwares para gestão de e-books, porém dentre as ferramentas encontradas são todas internacionais e não possuem especificidades administrativas de aquisição típicas de órgãos públicos brasileiros, como por exemplo: dados sobre empenho, prazos de pagamento, licitação, parecer da Assessoria Jurídica, data de publicação no Diário Oficial, dentre outros. Contudo, a Coordenadora indicou que ainda busca uma maneira de informatizar este processo com outras ferramentas, pois o tempo gasto nesta gestão manual é demorada. Parte do tempo de trabalho dos bibliotecários da CGB é para resolução de questões administrativas e burocráticas. 
Para descobrir novos títulos de e-books, a CGB conta com a sugestão da comunidade acadêmica (alunos, professores, especialistas e bibliotecários), eventos científicos, visita de editores na CGB, alertas de editor/agregador/distribuidor (nem sempre acontece) e trials. Em relação à retirada de títulos da coleção, alguns editores não avisam e não se responsabilizam pela retirada (consta em contrato), pois em algumas situações os direitos autorais do autor do título podem permitir a retirada do e-book, desta maneira, nem os próprios editores podem dar a garantia sobre a permanência de títulos na coleção assinada/adquirida. A CGB indicou que precisa pedir informações se houve alguma atualização na coleção (retirada/inclusão de títulos) e que a falta de aviso ocorre mais com empresas nacionais do que internacionais.

A CGB não conta com uma política de desenvolvimento de coleção de ebooks formalizada, porém possui um estudo de uso de e-books em que baseia suas decisões de seleção de bases de dados de e-books. Para cancelamento de assinatura e-books, procura tomar esta decisão com base na resposta da comunidade acadêmica, disponibilidade orçamentária, estatística de uso e estudo de satisfação do usuário.

Em relação às estatísticas, estas representam um grande problema para gestão de e-books. Segundo a CGB, a maior dificuldade é a maioria dos editores/agregadores/editoras não indicarem endereço IP (Internet Protocol) nas estatísticas, ou seja, a CGB não consegue obter estatísticas de uso por câmpus e por usuário (podendo fazer comparativos, como por exemplo, entre categorias de usuário: docentes, funcionários, graduação, pós-graduação, etc). Questiona-se também em relação a confiabilidade dos números, pois o fato de não haver referência ao número do IP não lhe dá garantia de que os números são dados reais.

A geração de estatísticas também é outro obstáculo, as ferramentas são confusas e cada uma possui interface diferente conforme 0 editor/agregador/distribuidor segundo os bibliotecários da CGB. A metodologia de coleta de dados não é clara, os termos utilizados para identificar os números das estatísticas são ambíguos ou desconhecidos pela equipe da CGB. Assim, muitas vezes a CGB depende do editor, distribuidor ou agregador explicar o que se referem as estatísticas extraídas. Além disso, muitas empresas não possuem ferramenta geradora de estatística para uso da biblioteca, devendo a CGB solicitar que o editor extraia as informações, o que nem sempre é realizado em tempo hábil, sendo que 
os agregadores demoram mais na resposta do que as editoras. A Coordenadora citou a necessidade de gerar as estatísticas das bases por meio de uma única ferramenta e não acessando cada base.

Em relação à questão de preservação digital dos e-books, muitas empresas em seus contratos garantem o acesso futuro à coleção mesmo que venha entrar em falência, por meio da filiação de projetos como PORTICO e LOCKSS. Os e-books são alocados no servidor do editor, distribuidor ou agregador. A CGB alega que não possui plataforma pesquisável para armazenamento dos arquivos do e-book e como prefere trabalhar com assinaturas, a questão da gestão de armazenamento de ebooks na plataforma é de responsabilidade do editor/agregador/distribuidor.

Dentre os principais problemas nas etapas de gestão de e-books contatados na entrevista com a CGB, apresenta-se no quadro 8:

Quadro 8 - Principais problemas nas etapas de gestão de e-books apontados nas entrevistas com a CGB

\begin{tabular}{|c|l|}
\hline Etapas & \multicolumn{1}{|c|}{ Problemas } \\
\hline \multirow{5}{*}{ Aquisição } & $\begin{array}{l}\text {-Processo lento devido a: restrições institucionais, espera da análise } \\
\text { dos contratos pela Assessoria Juŕdica, processo de compra na } \\
\text { universidade é complexo, lento e burocrático; }\end{array}$ \\
-Gestão praticamente manual dos dados referentes à aquisição das \\
bases: processo lento e cansativo. Falta de softwares que realizem a \\
gestão dos dados de aquisição de acordo com o processo de \\
compra de órgãos públicos; \\
-Falta de concorrência entre editores, distribuidores e/ou \\
agregadores; \\
-Pouco poder de negociação da Unesp sozinha; \\
-Bibliotecários realizam mais trabalhos administrativos; \\
-Falta de informações dos editores, distribuidores e/ou agregadores; \\
-Alerta de inclusão ou exclusão de títulos da coleção; \\
-Dados estatísticos confusos; \\
-Falta de confiança nos dados estatísticos, pois não são atribuídos a \\
IPs; \\
- Quadro de funcionários enxuto (aposentadorias com vagas não \\
repostas); \\
- Falta de política de desenvolvimento de e-books formalizada. \\
\hline Armazenamento \\
$\begin{array}{l}\text {-Armazenamento fica a cargo do editor/agregador/distribuidor; } \\
\text {-CGB não possui plataforma pesquisável para alocar arquivos de e- } \\
\text { books. }\end{array}$ \\
\hline
\end{tabular}

Fonte: autoria própria. 


\subsection{Entrevistados: diretores de biblioteca}

As bibliotecas dos campi da Unesp são responsáveis pela aquisição, armazenamento, acesso, busca, capacitação, divulgação/marketing e tratamento da informação. A partir do roteiro semiestruturado de entrevista, buscou-se coletar informações de como os diretores de biblioteca trabalhavam com questões e desafios apontados pela literatura na gestão de e-books, além disso, verificaram-se também questões de organização do trabalho.

\section{Em relação ao usuário foi constatado a partir das entrevistas com diretores que:}

- A finalidade de uso da informação pelo usuário influencia o uso ou não do ebook: usuários preferem usar e-book para pesquisas e localizar informações pontuais, uma vez que a maioria das bases de dados de e-books oferecem recurso de localizador de texto. Entretanto, para estudo com a leitura de várias páginas ou preparação para uma prova, os usuários apresentam preferência pelo livro impresso, mesmo com o uso de dispositivos próprios para leitura - e-readers - os usuários preferem o físico devido ao conforto visual.

- Usuários de áreas de Exatas e Biológicas que têm perfil de pesquisador tendem a procurar mais e-books: aponta-se que alunos de pós-graduação por já terem o hábito de utilizar recursos de pesquisa e informação da biblioteca, procuram com mais frequência e-books do que a graduação.

\section{Busca: como o usuário consegue pesquisar o e-book}

Todos os diretores com exceção de um diretor de biblioteca da área de humanas apontaram que os usuários sabem onde buscar e-books, ao entrarem na universidade, tanto calouros de graduação como pós-graduação recebem capacitação e material de divulgação da biblioteca sobre seus serviços e produtos. Contudo possuem dificuldades em elaborar estratégias de busca (seleção e combinação de palavras-chaves, utilização de campos e filtros de busca) e, portanto, demoram mais para recuperar resultados precisos e úteis.

Constatou-se também deficiência em competência informacional no perfil dos alunos ingressantes: a maioria dos diretores apontou que os usuários chegam à 
universidade sem experiência com pesquisa, uso de bibliotecas e busca de informações, inibindo-os de explorar os e-books. Aponta-se que muitos não sabem expressar o que buscam de informação em palavras-chaves e identificar o documento digital que está lendo (se é artigo, e-book, tese, etc).

Foi apontado que a dificuldade em utilizar filtros de pesquisa nas bases de dados de e-books, ocorre seja pela interface considerada como confusa ou incompreensível, seja pelo desconhecimento de como utilizar os filtros.

\section{Acesso: Como o usuário consegue acessar (ler) o e-book?}

Os diretores apontaram diversos obstáculos que os usuários se deparam para conseguir ler um e-book:

- Impossibilidade de download, impressão e leitura off-line: principal reclamação dos usuários ${ }^{16}$;

- Negação de acesso a títulos: bases de dados mostram o e-book, porém não é possível acessá-los. Usuários consideram confuso aparecer títulos que a Unesp não assina. Algumas bases têm a opção de filtrar somente 0 que a assinatura da Unesp cobre, mas ainda assim os usuários se sentem perdidos por aparecerem títulos não assinados na lista de resultados de uma busca;

- Usuários que possuem tablets ou e-reader: nem todos os equipamentos aceitam diferentes formatos de arquivo de e-book e a leitura de pdf em alguns e-readers não é confortável;

- A diversidade de tipos de restrições de acesso foi apontada por sete dos nove entrevistados como um desafio para gerenciar e instruir usuários. A maioria dos usuários se sente confusa e insegura ao descobrir que nem todas as bases de dados oferecem o mesmo tipo de acesso. Os diretores indicaram que procuram oferecer capacitações detalhadas com passo a passo para explicar esta diversidade. Nenhum dos diretores possuía uma relação das bases e seus respectivos tipos de acesso.

\footnotetext{
${ }^{16}$ Destaca-se que com exceção de um diretor, nenhum dos entrevistados sabiam que há bases de dados com restrição quanto ao acesso simultâneo.
} 
- Velocidade da internet no câmpus: metade dos entrevistados reclamou da velocidade da conexão disponível em suas unidades: demora para carregar os e-books.

- Em relação à interface das bases de dados de e-books, apenas três diretores, cada um proveniente de uma das três áreas do conhecimento relataram que os usuários apresentam dificuldades para conseguir utilizar as bases.

Constatou-se que é recorrente entre alunos de Exatas buscar pelo Google livros impressos digitalizados e publicados ilegalmente, assim, devido a esse acesso rápido e possibilidade de ter o download do livro como um todo, faz com que muitos alunos não utilizem as bases de dados de e-books assinadas pela universidade.

Ainda em relação ao acesso, diretores de bibliotecas de todas as áreas do conhecimento relataram que docentes manifestam preocupação quanto a permanência de acesso ao e-book, pois no caso de assinaturas há um receio de não haver acesso futuro caso não seja possível renovar a assinatura.

\section{Divulgação/Marketing: ações e canais de comunicação utilizados para divulgação dos e-books}

Entre os canais de comunicação todas as bibliotecas utilizam redes sociais e as capacitações para divulgação de e-books. Apenas uma biblioteca não utiliza email nas divulgações. Mural e folhetos são os canais menos utilizados. $\mathrm{Na}$ divulgação apresenta-se a existência de e-books na Unesp e onde encontrá-los. Destaca-se que as divulgações não são periódicas e sistemáticas e em apenas três bibliotecas o marketing é direcionado para públicos distintos (alunos de graduação, pós-graduação e docentes), sendo as demais divulgações não personalizadas por público. Os diretores reconhecem a necessidade de divulgar com maior frequência e com conteúdos mais específicos para cada público, porém alegam falta de bibliotecários e tempo para dedicarem esforços neste sentido.

Não há também estratégias formalizadas de marketing, cada biblioteca elabora seu material de divulgação sem estar integrado a um plano de divulgação, o marketing das bibliotecas depende da iniciativa, tempo e dedicação de cada biblioteca. $O$ fato desta divulgação não ser periódica, também dificulta a cultura de uso de e-books, por mais que os ingressantes passem por uma capacitação na 
biblioteca, ao longo do tempo se perde os conteúdos ensinados, sendo necessário sempre atualizá-los, o que poderia ser feito também via divulgação, porém estas ações ocorrem conforme a demanda e/ou quando aparece uma novidade.

Outro fato destacado pelos diretores é a apresentação da divulgação, ressaltaram que gostariam de uma assessoria de um profissional de marketing para elaboração de materiais mais atrativos e informativos.

A divulgação é um ponto unânime entre os diretores no que se refere a sua importância, reconhecem que são feitos poucos esforços devido a falta de tempo, estrutura e funcionários, sendo que acreditam que muitos usuários não utilizam ebooks por falta de conhecimento. Mesmo com as capacitações para ingressantes, ainda assim aparecem usuários na biblioteca que desconhecem que há acesso de e-books na universidade. $O$ boca-a-boca ainda é o meio mais eficaz de fazer 0 usuário ter conhecimento e interesse pelo recurso. Destaca-se também que os docentes são uma ponte fundamental para que os usuários conheçam e usem ebooks: quando o professor é usuário de biblioteca e cobra pesquisas com fundamento em literatura, os alunos tendem a usar mais a biblioteca. Um diretor entrevistado comentou que está procurando dar mais capacitações para docentes do que para alunos, pois os alunos que vão a biblioteca são de docentes que utilizam a biblioteca.

\section{Tratamento da informação: fatores que afetam a catalogação e indexação dos e-books}

Em relação à catalogação de e-books, este material não é catalogado pelas bibliotecas, pois os registros descritivos destes são fornecidos pelas empresas responsáveis pelas bases, contudo os diretores destacam a má qualidade dos registros, em que necessitam ser revisados conforme os padrões de catalogação da Unesp.

A maioria dos diretores de biblioteca citou que há necessidade de revisão das normas de catalogação para o tratamento de recursos eletrônicos no geral, não apenas e-books. Mais da metade apontou a necessidade de revisão do processo de catalogação e indexação na Unesp, o qual foi considerado detalhado e moroso, ocupando tempo que poderia ser gasto em outras atividades. 
Como os próprios bibliotecários não catalogam e indexam e-books, houve poucas informações dadas pelos diretores de biblioteca nesta etapa de gestão de ebooks.

\section{Capacitação: cursos para formação e orientação de usuários e bibliotecários}

Em relação à capacitação dos bibliotecários os seguintes temas foram considerados relevantes pelos diretores: questões legais sobre a aquisição, exclusão, cancelamento e renovação de bases de dados; direitos autorais; mercado editorial; bases de dados e equipamentos de leitura. Destes temas, os entrevistados apontaram algumas dificuldades e dúvidas que gostariam de compreender melhor:

- Modelos de negócio e mercado editorial: o bibliotecário geralmente não está a par das novidades de títulos e bases no mercado, impedindo-o de encaminhar para a CGB sugestões de assinaturas. Além disso, sentem dificuldade de explicar ao usuário o tipo de acesso permitido, por exemplo, bases que não permitem download ou que a quantidade de acesso simultâneo de usuários é limitada, estes tipos de acesso estão ligados ao modelo de negócio trabalhado pela editora, distribuidor ou agregador. $\mathrm{O}$ usuário questiona porque ele tem restrição de acesso e o bibliotecário não sabe responder. O serviço acaba perdendo a credibilidade para o usuário, que considera que o acesso não é concedido por erro de sistema ou falta de renovação de assinatura.

- Direitos autorais: bibliotecários apresentam dúvidas sobre o que é legalmente permitido se tratando de e-books: pode-se publicar um e-book no site ou rede social para divulgação? Pode-se compartilhar um e-book com um usuário? O professor pode publicar um e-book na plataforma de ensino da disciplina (Moodle, por exemplo)?

- Dispositivos de leitura (e-readers): saber escolher o melhor dispositivo de acordo com as necessidades dos usuários e coleções de e-books disponíveis: vantagens/desvantagens, incompatibilidade de arquivos, etc. Além de verificar se outra ferramenta não seria a melhor opção como um tablet ou notebook.

- Os diretores foram unânimes em relação a importância de um bibliotecário altamente qualificado, a questão não é somente número de bibliotecários, 
mas capacitação. Pode-se ter inúmeros recursos, porém se o profissional não sabe utilizá-los e instruí-los para seus usuários não há utilidade, na fala de um diretor : "Não adianta termos uma Ferrari se não há o piloto".

Os entrevistados apontaram a necessidade de capacitações contínuas, com temas mais práticos e com estudos de caso para resolver problemas reais das bibliotecas. Indicaram que os cursos fornecidos muitas vezes são muito teóricos e pouco práticos, sem exercícios. Além disso, os diretores ressaltaram que gostariam de ter capacitações mais especializadas de acordo com áreas de conhecimento e linhas de pesquisa que atuam. Também apontaram a preferência por cursos ministrados pela empresa que mantém a base de dados, pois esta possui maior conhecimento e detalhes do que muitas vezes um help-desk do Portal do Periódicos CAPES ou algum outro bibliotecário convidado. Metade dos entrevistados relatou que gostaria de ter pelo menos uma vez ao ano capacitações presenciais e não por videoconferência, pois permite maior troca de informações e colocação de dúvidas. Contudo, os diretores entendem que a atual conjuntura econômica do país e a logística para reunir bibliotecários de 24 cidades tornam difícil financeiramente realizar capacitações presenciais.

Quanto às capacitações oferecidas aos usuários, em todas as bibliotecas entrevistadas há um dia de capacitação para ingressantes na Unesp, seja graduação ou pós-graduação, no qual se explica como buscar e acessar e-books. Portanto, o usuário já entra na universidade sabendo que há e-books na biblioteca. Contudo, os diretores relataram que na capacitação muitos usuários se sentem confusos diante de tantos recursos de informação e têm dificuldades de concentração e assimilação dos locais para se buscar e como buscar. Por mais que se mostre que por meio de uma única interface (Parthenon, ferramenta de busca integrada da Unesp) é possível pesquisar os e-books hospedados em diferentes bases, ainda assim os diretores percebem esta reação dos usuários nas capacitações. O fato do usuário não ter uma bagagem de pesquisa em período escolar anterior também dificulta o aprendizado.

As capacitações para serem mais eficazes precisariam trazer informações específicas para as necessidades de um determinado público de usuários com perfis semelhantes, por exemplo: grupos de pesquisa, alunos de uma disciplina, etc. Focar mais em conteúdos especializados, personalizados e não em capacitações 
genéricas que apresentam apenas como realizar a busca de e-books na ferramenta de busca integrada ou no site da biblioteca. E para oferecer estas capacitações personalizadas para um público menor, demanda-se tempo do bibliotecário em conhecer as diferentes necessidades dos usuários, aprofundar-se em bases das áreas dos usuários e acompanhar mais de perto as mudanças e novidades das bases de dados. Os diretores apontaram que quando a capacitação atende exatamente a uma demanda específica de informação, os usuários se mostram mais interessados no uso de e-books.

Em três bibliotecas há capacitações específicas para grupos de pesquisa, mas com as demais há uma explicação mais genérica sobre bases de dados. Foi citado também a necessidade de capacitações com maior frequência, no geral, as bibliotecas disponibilizam cursos para os ingressantes na universidade e conforme surge a demanda.

Os diretores relatam que gostariam de oferecer mais capacitações, porém falta-lhes tempo e funcionários. A questão do tempo foi muito citada na fala dos diretores, em que há gasto de tempo com atividades burocráticas e administrativas, sobrando pouco tempo para dedicarem mais a planejamento e elaboração de capacitações.

\section{Organização do trabalho: rotinas de trabalho, organização das rotinas e comunicação entre órgãos da Unesp}

Quanto à organização do trabalho, todos os diretores relataram que os bibliotecários que trabalham com Referência sofreram maior impacto, pois são responsáveis em divulgar, capacitar e orientar o usuário, tendo o volume de trabalho aumentado nestas atividades. Um diretor de biblioteca relatou que as bases assinadas de e-books facilitaram seu trabalho, pois por meio delas é possível ter acesso a vários títulos sem precisar entrar site a site pesquisando e-books.

Não há formalmente um fluxo de gestão de e-books e se observa entre os diretores que com exceção de um diretor de biblioteca, as demais bibliotecas não vislumbraram a necessidade de criar um plano de gestão de e-books, com manuais de serviços assim como já ocorre com demais suportes de informação. Os e-books não trouxeram impactos significativos na rotina das bibliotecas em parte pela baixa demanda, segundo os entrevistados e também por não haver iniciativas para se mudar rotinas de trabalho a fim de que possam ser concentrados mais esforços para 
divulgação e capacitação de e-books.

Questionou-se nas entrevistas quais as dificuldades para poder se implementar novas rotinas de trabalho: dentre as respostas predominantes estão: número insuficiente de funcionários, excesso de atividades e tempo gasto com atividades administrativas e burocráticas. Contudo três diretores de biblioteca apontaram a falta de momentos de pausa para reflexão, crítica e planejamento das atividades ao longo do ano, podendo assim remanejar atividades e alterar prioridade de demandas, organizando melhor o tempo de trabalho e focando esforços em outras atividades e demandas mais prioritárias.

Foi também apontada pelos mesmos três entrevistados a falta de capacitação para os bibliotecários: a cada dia o serviço do bibliotecário se torna mais especializado, são conteúdos e suportes diversos para atender demandas específicas, assim, o atendimento deve ser mais personalizado, pois nisso estaria um dos diferenciais do serviço da biblioteca: atender demandas de informação específicas, pois demandas genéricas os usuários conseguem de forma independente em sites, porém a elaboração de estratégias de buscas e o conhecimento de coleções específicas são atribuições aos bibliotecários, os quais sem capacitação não conseguem oferecer um serviço com mais qualidade. Estes entrevistados relataram que para se manterem atualizados e conhecer as bases muitas vezes precisam sozinhos explorá-las, pois não há oferecimento de capacitação contínua.

Ainda em relação a capacitação, dois diretores de biblioteca apontaram o papel do bibliotecário como um educador, pois ensina e produz tutoriais e materiais didáticos, relataram a necessidade de capacitação relacionada a didática, a fim de poder planejar, elaborar e oferecer cursos de melhor qualidade aos usuários.

A falta de informação foi outro tópico abordado: os diretores relataram que Ihes falta informação de estatísticas de uso das bases, da incorporação ou retirada de títulos das bases de e-books, da validade de assinaturas, dificultando planejar e coordenar ações relativas a e-books. Esta ausência de dados impede diretores responderem numericamente questões como: quantos usuários do câmpus utilizam e-book? Seriam mais da graduação ou pós? Que coleções são mais utilizadas? Tenho novos títulos em uma base?

Ainda na questão sobre informações para realizar a gestão de e-books, a maioria dos bibliotecários citaram que dependem da CGB para informações relativas 
a período de assinatura de bases, títulos disponíveis, estatísticas e outras informações relativas a aquisição de e-books, alguns citaram demora na resposta, porém ressaltaram que muitas vezes a informação requisitada não dependia da CGB, mas sim de editores, distribuidores ou agregadores, porém a CGB poderia fazer maior pressão para cobrar retornos. A maioria dos diretores apontou que a intranet poderia ser melhor explorada, publicando documentos importantes como listas de títulos de e-books assinadas, estatísticas, vigência de assinaturas e ressaltaram que estas informações quando passadas por email se perdem e fica mais difícil a recuperação, assim como as bibliotecas não precisariam entrar em contato com a CGB, mas apenas consultariam a intranet. Outra crítica foi em relação ao site da CGB que é utilizado pelas bibliotecas para divulgar os e-books e outros serviços; consideram confusa a disposição das informações no site e que este seria "poluído" com muitas informações concorrentes. Houve também questionamento em relação à demora na resposta de problemas técnicos ou de acesso nas bases de dados e também em relação ao retorno de sugestão de aquisição de títulos de ebooks. Indicaram também que gostariam de receber alertas sobre inclusão e exclusão de títulos nas bases de dados de e-books.

Todos os diretores de biblioteca apontaram a necessidade de um profissional da área de Tecnologia de Informação no quadro de funcionários, pois necessitam de um apoio especializado na gestão de recursos eletrônicos para respaldo em caso de problemas técnicos de rede, acesso, internet, site da biblioteca, instalação, formatação, criação de programas, e ressaltaram que a cada dia os serviços e produtos da biblioteca são mais digitais, demandando a expertise deste profissional.

Por fim, no discurso da maioria dos diretores, percebe-se que o bibliotecário não é somente um profissional de apoio para as atividades de ensino, pesquisa e extensão na universidade, ele também é produtor de conteúdos, elabora materiais de capacitação, cria serviços personalizados para seus usuários, auxilia na edição de periódicos eletrônicos da universidade. Tal situação sinaliza também que o bibliotecário não é apenas usuário de tecnologia, mas desenvolvedor também. Nas entrevistas constatou-se que questões de interface, filtros de busca e apresentação da busca nas bases de dados devem ser desenvolvidas pelos bibliotecários junto com área de $\mathrm{Tl}$, uma vez que problemas de usabilidade das bases foram apontadas como resultantes da falta de conhecimento da área de $\mathrm{TI}$ do perfil e necessidades dos usuários. Dentre as principais constatações e problemas, indica-se no quadro 9: 
Quadro 9 - Principais problemas nas etapas de gestão de e-books apontados nas entrevistas com diretores de biblioteca

\begin{tabular}{|c|l|}
\hline Etapas & \multicolumn{1}{|c|}{ Problemas e questões } \\
\hline $\begin{array}{c}\text { Tratamento } \\
\text { da } \\
\text { informação }\end{array}$ & $\begin{array}{l}\text {-Há necessidade de revisão das normas de } \\
\text { catalogação para o tratamento de recursos } \\
\text { eletrônicos no geral, não apenas e-books; } \\
\text {-Necessidade de revisão do processo de } \\
\text { catalogação e indexação na Unesp, o qual foi } \\
\text { considerado detalhado e moroso. }\end{array}$ \\
\hline \multirow{5}{*}{ Divulgação } & $\begin{array}{l}\text {-Excesso de atividades administrativas impossibilita } \\
\text { oferecimento de divulgação personalizada e com } \\
\text { maior frequência; } \\
\text {-Divulgação dos e-books em capacitação, site, e- } \\
\text { mails e redes sociais; } \\
\text {-Conteúdo da divulgação: coleções de e-books e } \\
\text { onde encontrá-los; } \\
\text {-Poucos trabalham com divulgação especializada } \\
\text { para cada categoria de usuários; } \\
\text {-Não há uma estratégia de divulgação de serviços e } \\
\text { produtos formalizada e consolidada, estas ações } \\
\text { ocorrem conforme a demanda e/ou quando aparece } \\
\text { uma novidade; } \\
\text {-Muitos usuários não usam e-books por falta de } \\
\text { conhecimento, denotando uma falha na divulgação; } \\
\text {-Docentes são uma ponte fundamental para que os } \\
\text { usuários conheçam e usem e-books; } \\
\text {-Falta de funcionários dificulta oferecer divulgação } \\
\text { personalizada e com maior frequência; } \\
\text {-Necessidade de um profissional de marketing para } \\
\text { assessorar a divulgação. }\end{array}$ \\
\hline
\end{tabular}




\begin{tabular}{|c|c|}
\hline Capacitação & $\begin{array}{l}\text {-Na capacitação muitos usuários se sentem } \\
\text { confusos diante de tantos recursos de informação e } \\
\text { tem dificuldades de concentração e assimilação dos } \\
\text { locais para se buscar e como buscar; } \\
\text { - A questão do tempo foi muito citada na fala dos } \\
\text { diretores, no que se refere ao gasto de tempo com } \\
\text { atividades burocráticas e administrativas, sobrando } \\
\text { pouco tempo para dedicarem mais a planejamento } \\
\text { e elaboração de capacitações; } \\
\text {-Necessidade de capacitações mais personalizadas } \\
\text { e com maior frequência para usuários; } \\
\text {-Necessidade de capacitações contínuas e } \\
\text { realizadas pela empresa que oferece/mantém a } \\
\text { base de dados; } \\
\text {-Temas de capacitação necessários: mercado } \\
\text { editorial, dispositivos de leitura (qual o melhor para } \\
\text { adquirir), direitos autorais, bases de dados; } \\
\text {-Quando a capacitação atende exatamente a uma } \\
\text { demanda específica de informação, os usuários se } \\
\text { mostram mais interessados no uso de e-books; } \\
\text {-Preferência por parte dos bibliotecários de } \\
\text { capacitações presenciais, porém devido aos custos, } \\
\text { tem-se oferecido via videoconferência; } \\
\text {-Falta de funcionários para elaborar mais } \\
\text { capacitações e de melhor qualidade; } \\
\text {-Falta de funcionários altamente qualificados para } \\
\text { saber utilizar os recursos e instruir os usuários. }\end{array}$ \\
\hline Busca & $\begin{array}{l}\text {-Dificuldade em utilizar filtros de pesquisa nas bases } \\
\text { de dados de e-books, seja pela interface que não é } \\
\text { clara, seja pelo desconhecimento de como utilizar } \\
\text { os filtros; } \\
\text {-Usuários que tem perfil de pesquisador tendem a } \\
\text { procurar mais e-books; } \\
\text {-Deficiência de competência informacional no perfil } \\
\text { dos alunos ingressantes prejudica e dificulta a } \\
\text { busca de e-books. }\end{array}$ \\
\hline
\end{tabular}




\begin{tabular}{|c|c|}
\hline Acesso & $\begin{array}{l}\text {-Principal reclamação dos usuários quanto a e- } \\
\text { books: não ser possível fazer download e ter acesso } \\
\text { offline em algumas bases, esta é uma dificuldade } \\
\text { tecnológica para o usuário, porém é resultado do } \\
\text { modelo de negócio de contratado; } \\
\text {-Diversidade de formatos de arquivos: dificuldade } \\
\text { de e-readers; } \\
\text {-Diversidade de acesso; } \\
\text {-O tipo de necessidade de informação e atividade } \\
\text { influencia a predileção ou não por e-books; } \\
\text {-Idioma: falta de conhecimento de idioma por parte } \\
\text { do usuário o afasta do e-book; } \\
\text {-Professores demonstram receio quanto ao acesso } \\
\text { futuro do } \\
\text {-Velocidade da internet da universidade: lenta. }\end{array}$ \\
\hline $\begin{array}{l}\text { Organização } \\
\text { do trabalho }\end{array}$ & $\begin{array}{l}\text {-Falta de revisão de processos: atividades que } \\
\text { poderiam simplificadas ou eliminadas; } \\
\text {-O bibliotecário não é somente um profissional de } \\
\text { apoio para as atividades de ensino, pesquisa e } \\
\text { extensão na universidade, ele também é produtor } \\
\text { de conteúdos, porém falta tempo e funcionários; } \\
\text {-Volume de trabalho foi maior para bibliotecários da } \\
\text { área de Referência; } \\
\text {-Geração de estatística: interface confusa, não é } \\
\text { informado o IP dos dados extraídos, } \\
\text { desconhecimento da metodologia de coleta de } \\
\text { dados; } \\
\text {-Necessidade de um profissional de TI para auxiliar } \\
\text { em problemas técnicos, de acesso, formatação, } \\
\text { criação de programas. }\end{array}$ \\
\hline
\end{tabular}

Fonte: autoria própria.

\section{Análise: Áreas do conhecimento}

Em relação às respostas obtidas de entrevistados das áreas de Exatas, Humanas e Biológicas, detectamos as diferenças nos seguintes tópicos:

Idioma: a maioria dos títulos de e-books são publicados em inglês, $55 \%$ dos diretores apontaram esta ser uma barreira para os alunos. Bibliotecas com cursos de Exatas apontaram que a reclamação quanto ao idioma é rara. 
Uso: alunos de cursos de Biológicas e Exatas tendem a usar mais e-book para pesquisa do que alunos de Humanas. Contudo, alunos de Humanas Ciências Aplicadas têm se mostrado favoráveis ao uso de e-books. Em relação ao uso de ebook para estudo ou para uma leitura que demanda maior tempo, em todas as áreas do conhecimento havia uma preferência por impressos nesta situação, mesmo se houvesse e-readers.

Facilidade com tecnologia: usuários de bibliotecas de cursos de Biológicas e Exatas demonstraram maior facilidade na manipulação de e-books.

- Análise por: tamanho da biblioteca: unidades consolidadas (grandes) e unidades experimentais (pequenas)

As bibliotecas de unidades consolidadas se diferenciam das experimentais pelo número de bibliotecários e assistentes de biblioteca, quantidade de cursos e usuários atendidos. Nas unidades experimentais, com exceção de um câmpus, só existe um bibliotecário atuando. Notamos como diferença na gestão de e-books:

Infraestrutura: O bibliotecário não possui tempo para dedicar-se mais a capacitação e divulgação em campi experimentais, pois precisa dedicar-se a muitas atividades administrativas por ser o único bibliotecário e ao mesmo tempo responsável pela biblioteca. Possui menos recursos para divulgação e disponibilização de e-books, algumas bibliotecas consolidadas dispõem de e-readers para empréstimo. 


\section{DISCUSSÃO}

No estudo de caso constatamos problemas e dificuldades presentes na Rede de Bibliotecas da Unesp que dificultam o uso do e-book na universidade. Alguns destes problemas também são encontrados na literatura, os quais iremos discutir. Thompsom (2010), Walters (2013), Vasileiou, Hartley, Rowley (2012b), Maceviciute (2014), Bratanek (2013) discutem questões externas como comerciais e de mercado que afetam processos de desenvolvimento de coleções de e-books nas bibliotecas universitárias. Domínguez Aroca (2005), Castro Filho (2008), Senney, Ross e Mills (2009), Cunha (2010) e Jantz (2012a, 2012b) apontam questões organizacionais que afetam a estrutura interna das bibliotecas, ainda neste nível Mundt e Medaille (2011), Huff-Eibl, Voyles e Brewer (2011), Saunders (2012), Khumbhar (2012), Huvila et. al. (2013) e Vieira, Baptista e Cerveró (2013) discutem sobre a necessidade de novas competências para bibliotecários e tocam em tópicos relacionados a capacitação.

Por fim, os autores Orera-Orera (2007), Castro Filho (2008), Sennyey, Ross, Mills (2009), Cunha (2010), Furnival e Gracioso (2011), Jantz (2012a, 2012b), Michalak (2012), Finnemann (2014), Gradmann (2014) e Maceviciute (2014) trazem em comum discussões conceituais sobre biblioteca, auxiliando nossa análise de conceito de serviço de biblioteca universitária.

Para facilitar a apresentação da análise, dividimos as questões encontradas no estudo de caso e na literatura em questões externas às bibliotecas, questões organizacionais e questões conceituais.

\subsection{Questões externas}

Para início da análise, indicamos questões externas às Bibliotecas ou a CGB, as quais não conseguem modificar para melhorar o uso de e-books:

\section{- Questões comerciais}

A falta de concorrência entre editores, distribuidores ou agregadores e a comercialização de títulos por apenas um editor diminui o poder de negociação da universidade por preços e condições contratuais. Segundo bibliotecários da CGB: 
"Eu quero fazer negócio com uma editora, eu quero acesso por IP e não por senha, mas por mais que eu tente negociar isso com o editor eu não consigo. Ele não cede, pois ele sabe que é o único que detém o conteúdo. Se você não quiser comprar, não compra, ele vai vender para outro." (CGB).

Os autores Thompson (2010) e Walters (2013) colocam que sem maior relacionamento entre bibliotecas e editoras/agregadores será difícil a inclusão de ebooks nas bibliotecas acadêmicas. Uma das saídas para este entrave na negociação são os consórcios entre bibliotecas (VASILEIOU; HARTLEY; ROWLEY, 2012b; MACEVICIUTE, 2014), os quais funcionam amplamente em universidades norte-americanas (VASILEIOU; HARTLEY; ROWLEY, 2012b; BRATANEK, 2013) e conseguem exercer maior força para colocar demandas das bibliotecas aos editores, distribuidores ou agregadores.

Chamou nossa atenção o fato de que tanto na entrevista com a CGB como na literatura não encontramos referência a consórcio com outras universidades públicas, como as federais e também com particulares. O consórcio para e-books citado é somente entre as três maiores universidades estaduais públicas do Estado de São Paulo: USP, Unesp e Unicamp. No Brasil, o consórcio de bibliotecas que beneficia diversas instituições de ensino superior tanto pública como privada seria 0 Portal de Periódicos da CAPES, porém no Portal da CAPES ainda não encontramos acesso a e-books de diversas editoras acadêmicas, sendo necessário que as universidades negociem com editora a editora, agregador a agregador. Caso mais universidades além da USP, Unesp e Unicamp estivessem unidas em consórcio, o poder de negociação seria maior.

"Mas quando descobriu que são as três grandes universidades públicas interessadas, ai é outra coisa. O contrato não é só de uma, mas de três instituições. Ai fica mais fácil conversar." (CGB)

\section{- Exclusividade}

Algumas editoras, distribuidores e agregadores detêm o direito exclusivo de comercialização de determinados títulos, fazendo com que eles sejam detentores de conteúdo e as universidades só consigam acesso por meio da base de dados da editora, do distribuidor ou do agregador representante da editora. Este é um fato que 
coloca as universidades em desvantagem, pois acabam tendo que aceitar modelos de negócio praticados pelas editoras, interfaces das bases de dados não adequadas às necessidades de usuários, etc, pois é somente na base de dados daquele editor, agregador ou distribuidor que se consegue o acesso ao título solicitado pela comunidade acadêmica.

"Há alguns editores que não querem ceder, eles sabem que tem material bom, que só tem com eles. Eles dizem que esse é o modelo de negócio da empresa e é isso que tem para oferecer e ponto." (CGB).

A dificuldade de negociação com editores e a exclusividade que editoras detêm em comercialização de títulos (não deixando alternativas para escolha de outros fornecedores de e-books) dificulta o trabalho da CGB em selecionar bases de dados com menor restrição de uso, com melhor interface e usabilidade, com títulos de idiomas acessíveis e recursos de pesquisa mais compreensíveis, assim, a biblioteca não consegue atender algumas preferências dos usuários.

"Por mais que a base não tenha uma boa interface, as vezes o editor é o único que tem aquele conteúdo e a comunidade precisa do conteúdo. Então, não se tem muita escolha...O editor não muda a interface. Assinamos pelo conteúdo, ele é o único que tem." (CGB).

Esta é uma questão importante que impacta o uso de e-book dentro das bibliotecas. Os usuários ao se depararem com obstáculos para usar e-books por conta das condições comerciais impostas pelas editoras/agregadores/distribuidores acabam por preferir na biblioteca o livro impresso, buscam versões digitalizadas pirateadas na internet, ou adquirem e-books em livrarias, pois conseguem ter mais liberdade de uso. A compra para pessoas físicas via livrarias e lojas virtuais geralmente o acesso possui menos restrições do que para pessoas jurídicas: 0 usuário baixar o pdf da obra ou acessá-la somente na plataforma do editor/agregador, porém sem restrições de acesso simultâneo ou acesso via empréstimo virtual (período limitado). Contudo, ainda há o problema da exclusividade, pois o título só poderá ser acessado via determinada editora, agregador ou distribuidor. Walters (2013) e Vasileiou, Hartley e Rowley (2012b, p. 
290) colocam a importância da relação entre bibliotecas e empresas do mercado editorial de e-books para que haja uma integração consolidada dos e-books nas universidades.

\section{- Questões institucionais da universidade}

Detectamos alguns pontos de inflexibilidade na estrutura organizacional da universidade durante as entrevistas:

- Impossibilidade de adotar alguns modelos de negócio devido a inexistência de um cartão de crédito corporativo internacional na universidade. Em diversas editoras é possível a aquisição/assinatura selecionando alguns títulos e não por meio de pacote fechado de títulos, porém o pagamento é via cartão de crédito corporativo. Este modo de pagamento também agilizaria a disponibilização do conteúdo, por ser menos burocrático. Walters (2013) também indica dificuldade de adoção de modelos de negócio por formas de pagamento que não são permitidas nas instituições que a biblioteca está vinculada;

- Processos administrativos de compra da universidade são complexos, dependem de outros departamentos e têm prazos de execução que nem sempre atendem de forma hábil à demanda dos usuários das bibliotecas.

\section{- Informação dos editores, distribuidores ou agregadores}

Alguns editores (segundo os entrevistados, principalmente os nacionais) demoram para fornecer informações como estatísticas de uso e inclusão e exclusão de títulos da coleção de e-book. Mesmo quando os dados são disponibilizados, os entrevistados apontaram que são confusos, de maneira que os bibliotecários não conseguem compreender a apresentação dos dados e nem a sua origem (no caso de estatísticas, a CGB se queixa que alguns editores não indicam a procedência dos dados por meio de número de IPs):

"Cada um [editor] tem uma metodologia. Então é complicado, porque se você for fazer comparações não consegue. Você 
não sabe se o número está inflacionado ou não. Eu não acho muito confiável." (Diretor de Biblioteca).

"É difícil puxar os dados, pois cada um é de uma interface, cada um tem uma terminologia e método de coleta de dados." (CGB).

A literatura também aponta a problemática das estatísticas e a falta de dados dos editores/agregadores/distribuidores sobre a coleção (VASILEIOU; HARTLEY; ROWLEY, 2012b).

A falta de informação de editores/agregadores/distribuidores, principalmente em relação às estatísticas é um dado preocupante. Segundo os diretores de biblioteca e a CGB, não se sabe numericamente ao total quem seriam estes usuários de e-books (graduação, pós-graduação, docentes, por câmpus, por curso). Desta maneira, constitui-se um obstáculo para o planejamento da capacitação e divulgação entre os usuários, dificuldade também encontrada em Vasileiou, Hartley e Rowley (2012b) e Maceviciute (2014), pois é somente com conversas informais, estudos de usuários e nas capacitações que se detecta quem são os usuários de ebooks.

\subsection{Questões organizacionais}

\subsubsection{Gestão de pessoas, capacitação e divulgação}

A gestão de pessoas na universidade é um ponto citado entre os diretores como um impeditivo de contratar e avaliar funcionários que tenham e desenvolvam habilidades específicas. $\mathrm{O}$ quadro de vagas para contratação de funcionários para as bibliotecas contempla apenas cargos de bibliotecários, diretores de biblioteca, supervisores de seção de biblioteca e assistentes. Não é possível contratar funcionários de outras áreas para a biblioteca, apesar dos entrevistados apontarem a necessidade de um profissional de TI dentro da biblioteca, para compreender e atender demandas de produção de materiais e serviços que exigem conhecimentos de manutenção de sites, programação, edição digital, etc:

"Porque a gente trabalha de uma forma as vezes muito amadora, por tentativa, 'olha isso aqui deu certo, vamos fazendo', eu acho que um profissional de TI seria interessante." (Diretor de Biblioteca). 
"Você tem ideias e não tem quem faça aquilo acontecer. Inclusive o pessoal de TI da universidade como um todo, eles não vivenciam nossas necessidades, estão por fora do ambiente de biblioteca e não conseguem captar direito o que seria que queremos. Assim, para colaborar no desenvolvimento de programas, alguém que entenda de web design, essas coisas." (Diretor de Biblioteca).

Assim como os diretores sentem a necessidade de equipes interdisciplinares, a literatura também destaca a importância destas equipes (DOMÍNGUEZ AROCA, 2005; CASTRO FILHO, 2008; CUNHA, 2010). Além disso, a quantidade de vagas no quadro de funcionários é limitada, não sendo possível contratar mais pessoas mesmo que haja necessidade, conforme verificamos nas falas dos diretores entrevistados:

"Enfim a própria política de contratação da Unesp tem complicado um pouco. Não dá para mudar o subquadro, só pode contratar a quantidade e os cargos descritos ali." (Diretor de Biblioteca).

Os diretores de bibliotecas apontam a necessidade de maior quantidade de funcionários, porém de profissionais com qualificações e habilidades específicas:

"Tudo bem que ajuda ter vários funcionários, mas sem uma capacitação para aquela área específica não adianta, precisamos de profissionais com competência em tecnologia, mas não só como usuário, mas como produtor de conteúdo, precisamos saber mais de gestão, saber planejar, precisamos saber mais de marketing, comunicação digital, entende? Posso ter vários funcionários, mas isso não vai fazer diferença se você não tiver o conhecimento técnico de como acessar, desenvolver materiais online, eu acho que é mais rico a competência de cada um do que realmente a quantidade." (Diretor de biblioteca).

"O bibliotecário é também um educador, precisamos mais de competências didáticas para desenvolver melhores capacitações e tutoriais para nossos usuários." (Diretor de biblioteca).

"Falta de conhecimento de técnicas de edição de imagens, de técnicas de marketing." (Diretor de Biblioteca). 
As falas dos entrevistados se aproximam dos autores Huff-Eibl, Voyles, Brewer (2011), Saunders (2012), Huvila et al., (2013), Vieira, Baptista e Cerveró, (2013), os quais também citam necessidade de profissionais que tenham novas habilidades, competências e perfis para o bibliotecário:

- Novas tecnologias de informação e comunicação;

- Redes sociais;

- Marketing;

- Edição de materiais digitais;

- Criação e manutenção de conteúdos de websites;

- Perfil educador, desenvolver competências relacionadas a aprendizagem.

- Perfil mais flexível, colaborativo e facilitador de negociações;

- Habilidades gerenciais;

- Pensamento analítico.

Percebe-se que nas entrevistas com os diretores encontramos as mesmas necessidades de competências e perfis nos autores citados. Os diretores relataram dificuldades de contratar bibliotecários neste perfil devido a forma de contratação da universidade via concurso público, porém há tentativas de melhorar este processo de contratação de funcionários com aperfeiçoamento de editais de concursos. Contudo, os diretores de biblioteca ainda ficam na dependência do sistema de contratação via concurso público que seleciona pessoas de acordo com o edital previsto. Os diretores afirmam que nem sempre o concurso consegue selecionar pessoas que tenham perfil flexível e comunicativo, mesmo com as fases de testes psicológicos. Além disso, após a contratação, o diretor não tem muitas ferramentas para promover ou dispensar funcionários, pois mesmo com os meios disponíveis para acompanhar e avaliar o desempenho do funcionário, não existe uma carreira de bibliotecário, assim, não há como o bibliotecário subir de cargo, a não ser que assuma um cargo de direção ou supervisão. Assim, fica difícil motivar o bibliotecário pela ausência de promoções em cargos:

"Não tem plano de carreira para bibliotecários na universidade. A política de gestão de pessoas não é adequada. Não consigo 
motivar funcionários a se aperfeiçoarem em cursos, porquê se esforçar se não há plano de carreira?" (Diretor de biblioteca).

O fato também de funcionários terem a estabilidade de emprego na universidade pública, dificulta para o diretor implementar mudanças e cobrar novas atitudes de funcionários:

"Eu tenho dificuldade de implementar mudanças com funcionários mais antigos da casa. A maioria não aceita mudanças e o pior é que isso contamina os mais jovens. Eu tenho que esperar a pessoa se aposentar ou sair da universidade." (Diretor de biblioteca).

Em relação à capacitação de bibliotecários, temas como modelos de negócio, direitos autorais, mercado editorial e dispositivos de leitura apontados pelos autores Vasileiou, Hartley e Rowley (2012b) e Walters (2013) como relevantes para a capacitação de bibliotecários foram considerados também importante pelos diretores de biblioteca. O desconhecimento principalmente da dinâmica dos modelos de negócio tornam as bibliotecas alheias a diversos desafios que os e-books trazem como por exemplo: os tipos restrições de acessos, a diversidade de formatos de arquivos que só funcionam em determinados e-readers ou softwares, a exclusividade de editoras/agregadores/distribuidores sobre determinados títulos, etc. Deste modo, as bibliotecas ficam despreparadas para atender usuários e explicarIhes as diferentes formas de acesso, saber comprar dispositivos de leitura adequados, etc. Esta questão de falta de percepção das problemáticas do e-book pelas bibliotecas acadêmicas também é citado por Walters (2013).

Mesmo que estes temas de capacitação fossem trabalhados, os diretores relatam que a capacitação apenas teria repercussão se fosse parte de um programa contínuo de aperfeiçoamento profissional. Os diretores relatam que o autodidatismo é comum pela falta de capacitação e que algumas informações e competências se adquirem conforme surge a ocasião ou necessidade:

"Há necessidade de mais capacitações e com maior frequência. Precisamos de capacitações sempre, estarmos sempre atualizados, as coisas mudam muito." (Diretor de Biblioteca). 
"Você não tem tempo de ficar vasculhando tudo [bases de dados] e aprendendo tudo na raça." (Diretor de Biblioteca).

"Mas a nossa lei de direito autoral é tão rígida que a gente sempre se surpreende com coisas que a gente faz e que não poderia fazer." (Diretor de Biblioteca).

"Muitas vezes eles [bibliotecários] são surpreendidos com uma assinatura de base nova, eles falam que não sabiam que tinha." (Diretor de Biblioteca).

Autores indicam a necessidade de mais capacitações para bibliotecários (RIBEIRO, 2012; WALTERS, 2013; MACEVICIUTE, 2014) indo ao encontro das falas dos diretores.

Foi observado nas entrevistas e também na literatura (CASTRO FILHO, 2008; CUNHA, 2010; MUNDT; MEDAILLE, 2011) o papel cada vez mais presente do bibliotecário como educador/mediador, aquele que irá orientar, ensinar e guiar o usuário a utilizar fontes de informação, tecnologias de pesquisa, estratégias de busca, etc. Este compartilhamento de conhecimento do bibliotecário com o usuário se mostra um dos valores de serviço mais diferenciais das bibliotecas. Tal valor é fundamental para uma das dificuldades dos usuários apontadas pelos diretores de biblioteca: a deficiência em competência informacional. Usuários de graduação chegam a biblioteca sem noções sobre como realizar pesquisas bibliográficas, não dominam as técnicas e recursos de busca, sendo necessário um apoio de profissional especializado e portanto, altamente qualificado.

Um problema apontado na literatura (VASILEIOU; HARTLEY; ROWLEY, 2012b; MACEVICIUTE, 2014) e constado nas entrevistas é a falta de um plano de divulgação, configura-se como um problema pois não há foco e regularidade no desenvolvimento das ações de divulgação das bibliotecas. Há várias iniciativas de marketing, porém isoladas umas das outras bibliotecas da Rede de Bibliotecas da Unesp, há bibliotecas que criam materiais de divulgação online e impressos que poderiam ser aproveitadas por outras bibliotecas. Há informações que são gerais de e-books que servem para os usuários de qualquer biblioteca da Unesp e outras informações que podem ser personalizadas para as necessidade de diferentes grupos de usuários. As informações do tipo padrão, como por exemplo onde procurar e-books, poderiam ser divulgadas em materiais-padrão para todas as bibliotecas da Rede, otimizando tempo de trabalho dos bibliotecários. 
Contudo há informações de coleções de e-books que são específicas de determinadas linhas de pesquisa e áreas do conhecimento, nestes casos, pode-se realizar divulgação personalizada para atingir o público alvo mais adequado. Com o excesso de informações já lançadas aos usuários, estes ao se depararem com uma divulgação geral usando a mesma linguagem e informação para diferentes grupos de usuários podem desconsiderar as divulgações das bibliotecas, minimizando o alcance dos e-books:

"O excesso de informações causa algumas distorções, então, quando temos um contato pessoal funciona melhor, uma coisa mais personalizada." (Diretor de biblioteca).

A personalização das divulgações, como informações específicas para determinados públicos, não é uma prática comum das bibliotecas entrevistadas. Percebe-se nas entrevistas que a falta de um plano de marketing com ações contínuas e periódicas e conteúdos direcionados para diferentes grupos de usuários, implica em dificuldades das bibliotecas em divulgarem e-books aos seus usuários:

"Conforme precisa a gente coloca informação. Não tem uma periodicidade, conforme as informações chegam ou precisa vamos divulgando." (Diretor de biblioteca).

"Nós não temos a prática de divulgar intensamente e de maneira estratégica, ou seja, informação específica para público específico no tempo certo. Não adianta ter recursos se os alunos não sabem, nós fazemos divulgação, mas precisamos divulgar de forma mais planejada." (Diretor de biblioteca).

A falta de ações coordenadas e planejadas de divulgação dificultam que o uso de e-books seja expandido nas bibliotecas universitárias. Há questões intrínsecas aos usuários que influenciam o uso ou não de e-book como preferências de suportes para leitura (impresso, e-reader, tablets, computador, etc), apesar de ser um dos fatores fundamentais para compreender o uso de e-books em bibliotecas, o foco desta pesquisa não é explorar preferências de leitura, gostos ou interfaces com melhor usabilidade, mas sim produção de serviços das bibliotecas. Um dado detectado nas entrevistas e que pode auxiliar bibliotecas a melhor divulgar e capacitar seus usuários: dependendo do tipo de informação/atividade que o usuário 
necessita, este demonstrará maior ou menor grau de interesse por e-books, por exemplo: a procura era menor por usuários que utilizariam livros para estudar para provas e fazer exercícios, porém maior entre usuários que buscavam livros para pesquisas bibliográficas.

Retomando a abordagem de gestão de serviços de Zarifian (2001), a produção de serviço atende as condições de atividade do usuário, portanto, a biblioteca deve estar atenta ao tipo de atividade que o usuário precisa desempenhar e atuar nesta necessidade: prestar uma prova ou realizar um levantamento bibliográfico, por exemplo, são atividades acadêmicas distintas e a biblioteca deve estar atenta aos suportes de informações mais adequados e preferíveis pelos usuários, para assim efetivamente produzir um serviço.

\subsubsection{Estrutura organizacional}

\section{- Planejamento}

Observando mais atentamente a organização da biblioteca para produção de serviços, percebemos um grau de dificuldade de assimilação de novas atividades/serviços seja pela falta de capacitação, pelo quadro de funcionários reduzido, pelas burocracias administrativas, mas notavelmente pela falta de formalização de processos de trabalho, revisões de processos de trabalho e elaboração de planejamentos.

A maioria dos diretores de biblioteca teve dificuldades de responder ao questionamento: "haveria alguma atividade no trabalho dos bibliotecários que estaria obsoleta e/ou poderia ser otimizada?" O relato foi que nunca haviam parado para pensar nesta questão em seu cotidiano profissional. Observou-se entre a maioria dos diretores entrevistados a falta de planejamentos anuais em algumas bibliotecas, e a formalização de processos de trabalho e de reuniões periódicas com a equipe para notar necessidades, incongruências, dificuldades e desafios:

"Às vezes a gente fica um pouco atropelado pelas rotinas. E se a gente não põe um cronograma, não coloca meta em ações, a gente se perde um pouco mesmo";

"Realmente falta mais uma visão gerencial, fazer planejamentos, rever periodicamente metas com a equipe"; 
"Nem todos os processos de trabalho estão formalizados, então, fica difícil revisá-los e ver se tem algo obsoleto. Precisamos terminar de formalizar os processos".

Não havia discussões na equipe sobre revisão de rotinas de trabalho. Quando havia planejamento era voltado para como executar atividades para atender demandas atuais, não se pensava em fazer prospecção de demandas futuras. Desta maneira, quando surgem novas atividades ou produtos na biblioteca, tem-se dificuldade de incorporá-los por não haver uma organização de discussão de remanejamento de rotinas de trabalho, focam-se esforços e planejamento para necessidades presentes, não há iniciativas para detectar problemas ou necessidades futuras.

Jantz (2012a) e Wilkins (2007) indicam que bibliotecas precisam melhorar em aspectos gerenciais, realizar planejamentos acurados com ambiente externo e necessidades de usuários, assim como estabelecer metas menos abstratas, mas que possam ser operacionalizadas.

A ausência de processos de trabalho formalizados acaba por dificultar a visualização de etapas dos processos que poderiam ser melhorados, mudados ou suprimidos. Pela formalização não ser prática comum entre a maioria das bibliotecas, não há políticas escritas para a gestão de e-books: as ações e iniciativas de divulgação, capacitação, por exemplo, são tomadas conforme o diretor da biblioteca, podendo ser alteradas em mudança de gestão. Assim, corre-se o risco de não haver continuidade de ações e uma forma padronizada de lidar com os e-books entre os funcionários das bibliotecas.

\section{- Monitoramento do ambiente externo}

Há uma tendência nas bibliotecas acadêmicas em assimilação ou absorção de mudanças provocadas pelo ambiente externo e não antecipação de demandas, a reação é passiva às transformações externas (JANTZ, 2012a) e também pela falta de discussões e planejamentos. Contudo as intensas, rápidas e constantes mudanças em tecnologias, indústria de publicações, métodos de ensino, etc, inevitavelmente trazem questões que demandam das bibliotecas novos posicionamentos e ações, pois senão correm o risco de se tornar obsoletas e de se deixar levar passivamente pelas transformações do ambiente externo. Jantz (2012a, p. 538) coloca que a biblioteca necessita ter um senso de urgência em responder ao 
ambiente externo. Entre os diretores de bibliotecas notamos que falta monitoramento do mercado editorial e indústria de publicações, as novidades e os dados são captados em eventos da área de Ciência da Informação ou por bibliotecários que têm iniciativas de procurar informações, mas não que o monitoramento externo seja parte da rotina de trabalho:

"O que sabemos dos editores é quando recebemos notícias da CGB ou quando nós mesmos procuramos. Novidades assim sabemos mais em eventos também. Mas é esporádico." (Diretor de biblioteca).

Há sim pesquisa de opinião de usuários e estudos de usuários para avaliação de serviços nas bibliotecas da Unesp, porém isto não é suficiente para a bibliotecas se prepararem para as demandas de usuários, pois parte destas provém do ambiente externo, desta maneira, a ausência de monitoramento dificulta a reação da biblioteca universitária a mudanças assim como de se antecipar e se preparar melhor para transformações.

\section{- Autonomia}

Diretores de biblioteca apontaram que algumas das atividades desenvolvidas pelos bibliotecários, como por exemplo catalogação e indexação, apresentavam excesso de informações, o que acabava por ocupar tempo de trabalho com detalhes que segundo os diretores eram desnecessários e não influenciavam a recuperação e a organização de documentos. Contudo, os diretores precisam seguir as orientações técnicas que a CGB coloca para o desenvolvimento de algumas atividades e rotinas na biblioteca, desta maneira, o diretor encontra inflexibilidade em alterar certas atividades.

A fim de organizar os serviços e produtos de 30 bibliotecas da Unesp (UNESP, 2015a), a CGB determina fluxos e procedimentos de rotinas de trabalho, como Empréstimo Entre Bibliotecas, catalogação, indexação, Empréstimo Unificado, inserção de trabalhos acadêmicos no repositório institucional, etc. Como as bibliotecas compõem uma Rede é necessário seguir uma padronização de atividades, porém os diretores indicaram falta de autonomia para modificar procedimentos técnicos que iriam desonerar o tempo de trabalho dos bibliotecários. 


\section{- Flexibilidade da estrutura}

Jantz (2012a,b) coloca que estruturas com hierarquia rígida e burocracias são entraves para a biblioteca enfrentar as transformações do ambiente externo. A figura do gestor da biblioteca é fundamental neste processo, o qual precisa flexibilizar a biblioteca para que esta atenda novas demandas, porém é necessário manter algumas atividades e funções tradicionais (armazenamento, atendimento ao usuário, catalogação, etc) que são necessárias para serviços atuais que ainda se fazem necessários. É preciso que a biblioteca se organize para mudanças, porém há estruturas que são mantidas, pois uma mudança radical iria prejudicar serviços consolidados e ainda válidos. Contudo, a estrutura organizacional e o quadro de funcionários são implementados pela universidade, não sendo possível para os diretores de biblioteca e nem para a Coordenadoria Geral de Bibliotecas alterarem esta situação.

Sennyey, Ross e Mills (2009) apontam que a biblioteca mais do que reorganizar processos de trabalho e estruturas organizacionais, necessita rever seus conceitos. Qual o conceito de serviço que ela se propõe a trabalhar? A mudança na biblioteca exige primeiramente uma mudança conceitual, pois senão será descontextualizada e não haverá resultados e adesão a longo prazo: "Mas para planejar o futuro em um cenário de rápidas mudanças de informação, líderes de bibliotecas devem começar por enfrentar um problema de definições conceituais que atualmente obscurecem os esforços para articular um futuro para as bibliotecas" (SENNYEY; ROSS; MILLS, 2009, p. 252, tradução nossa).

Em consonância com a literatura, no discurso dos diretores de biblioteca, também se percebe uma necessidade de alterações não apenas estruturais, mas também conceituais:

"Assim, precisamos de nova roupagem, novos ideais para o que queremos ofertar de serviço. Não é mais só oferecer informação, nós ajudamos o usuário a construir informação. Isso é mudança de paradigma. Mas não adianta eu comprar tecnologias novas, querer mudar o trabalho se as ideias, a cultura não for mudada também." (Diretor de biblioteca).

Percebe-se que a necessidade trazida pelas entrevistas e também na literatura não é somente a de mudança de suportes de informação na biblioteca ou 
técnicas diferentes de produção do serviço, mas é algo interno, como as bibliotecas se posicionam para ofertar seus serviços. Diretores de biblioteca e CGB reconhecem que a forma como a biblioteca hoje se estrutura organizacionalmente precisa de mudanças, porém não é somente mudança de técnica, tecnológica e de processos, mas sim o ideal que está por trás desta estrutura e seus serviços. Não adiantaria implementar mudanças sem a adoção de uma nova mentalidade.

\subsection{Questões conceituais}

Rever isoladamente estruturas organizacionais desvinculadas da redefinição dos serviços não trará resultados consolidados para as bibliotecas, pois é necessária uma nova visão do papel e do objetivo dos serviços da biblioteca (ORERA-ORERA, 2007; CASTRO FILHO, 2008; SENNYEY, ROSS, MILLS, 2009; CUNHA, 2010; FURNIVAL, GRACIOSO, 2011; JANTZ, 2012a, 2012b; MICHALAK, 2012; FINNEMANN, 2014; GRADMANN, 2014; MACEVICIUTE, 2014). As bibliotecas acadêmicas estão passando por redefinições conceituais por não atenderem mais plenamente as demandas dos usuários: passa de difusora de informação para produtora de informação (CASTRO FILHO, 2008; SENNYEY, ROSS, MILLS, 2009; JANTZ, 2012a, 2012b; FINNEMANN, 2014; MACEVICIUTE, 2014). Dentre os entrevistados, havia diretores que desconheciam o referencial teórico da biblioteca como produtora de informação e mesmo assim citaram pontos que fazem parte dos conceitos da biblioteca produtora de informação. A seguir indicamos os conceitos citados pelos diretores de biblioteca que também são encontrados na literatura, indicamos os autores que convergem com as falas dos diretores (ORERA-ORERA, 2007; CASTRO FILHO, 2008; SENNYEY, ROSS, MILLS, 2009; CUNHA, 2010; FURNIVAL, GRACIOSO, 2011; JANTZ, 2012a, 2012b; MICHALAK, 2012; FINNEMANN, 2014; GRADMANN, 2014; MACEVICIUTE, 2014):

- Personalização: De acordo com os diretores, a biblioteca é solicitada a atender necessidades de informação específicas e apresentar o serviço de forma personalizada, por exemplo: ao invés de uma capacitação geral para alunos de graduação, haveria capacitações em disciplinas com bases de dados específicas, em grupos de pesquisa, etc. Segundo um diretor de biblioteca: 
"O atendimento exige mais dos bibliotecários, é a cada dia mais especializado. Em relação às bases de dados preciso ir lá, entrar, decifrar e ver o acesso e saber mostrar para o usuário a informação específica que ele precisa do jeito que ele entenda." (Diretor de biblioteca).

Esta constatação na pesquisa em campo vai ao encontro da literatura, a qual aponta que usuários demandam atendimento e serviços mais personalizados, não basta apenas oferecer recursos para pesquisa e fontes de informação.

- Biblioteca como produtora de conteúdos: na fala dos diretores de biblioteca e CGB vemos a biblioteca não mais como apenas fornecedora de informação, mas produtora de informação:

"A gente não atua apenas como usuário de informação para repassar informação, mas também como desenvolvedor de recursos".

A literatura coloca que bibliotecas produzem materiais como: tutoriais, materiais didáticos, manuais, além de auxiliar usuários em gestão de direitos autorais, de repositórios institucionais e análises bibliométricas. (SENNYEY; ROSS; MILLS, 2009; CASTRO FILHO, 2010).

- A biblioteca se desenvolve em meio digital: os diretores colocaram que a biblioteca não apenas usa tecnologia como forma de automatização e otimização de atividades, mas as utiliza para produzir informação e produzir serviços, ou seja, as ferramentas online e eletrônicas são a própria plataforma que a biblioteca se utiliza para produzir serviços: chats online, cursos em plataformas Moodle, etc. (AMIN; GERBIC, 2010).

- O espaço da biblioteca: o espaço da biblioteca para estudo individual e coletivo, convivência, debates, salas multimídia para produção de materiais são valorizados pelos autores (CUNHA, 2010; PESCH, 2013; MACEVICIUTE, 2014), aproximando-se das repostas dos diretores, que colocaram o espaço físico como importante para as atividades acadêmicas dos usuários: 
"O usuário precisa de um lugar para estudar e fazer seus trabalhos e pesquisa, a biblioteca precisa oferecer laboratórios para isso, hoje nós vemos os laboratórios da área de informática vazios e os laboratórios de computadores das nossas bibliotecas cheios, nós temos conteúdo e profissional para ajudá-los não apenas equipamentos." (Diretor de biblioteca).

- Bibliotecário como educador: o bibliotecário ensina e orienta os usuários no uso e busca de recursos de informação, além de produzir materiais didáticos:

"O bibliotecário é também um educador, precisamos mais de competências didáticas para desenvolver melhores capacitações e tutoriais para nossos usuários." (Diretor de biblioteca).

A visão do bibliotecário como educador é vista também na biblioteca como produtora de informação (CASTRO FILHO, 2008; CUNHA, 2010; MUNDT; MEDAILLE, 2011)

- Competência informacional: as bibliotecas como produtoras de informação auxiliam na formação de usuários autônomos e com habilidades e competências em pesquisa, análise e síntese de informação. $O$ ambiente não é somente de pesquisa, mas de aprendizagem (CASTRO FILHO, 2008; CUNHA, 2010; MUNDT, MEDAILLE, 2011). Os diretores de biblioteca da Unesp também colocam a importância da competência informacional para desenvolver nos usuários:

"Muitos usuários não sabem montar estratégias de pesquisa, não sabem quais fontes de informação usar, então, nós temos que auxiliá-los a desenvolver competências para busca e uso de informação" (Diretor de biblioteca). 
- Equipes multidisciplinares/assessoria profissional: a literatura aponta que o uso de meios digitais e online para oferecimento e produção de serviços, questões de direitos autorais, divulgação de recursos, colocam a necessidade de equipes com profissionais de outras áreas para auxílio em questões específicas para a biblioteca: como informática, editoração, direito, marketing, etc. (DOMÍNGUEZ AROCA, 2005; CASTRO FILHO, 2008; CUNHA, 2010). Os diretores de biblioteca também apontaram nas entrevistas a necessidade de auxílio de outros profissionais.

- Gestão da biblioteca: Jantz (2012b) e Finnemann (2014) colocam que a gestão da biblioteca necessita ser mais estratégica, planejar-se mais com alvos de curto a longo prazo, com processos de trabalho mais flexíveis e dinâmicos. Esta visão também é compartilhada pelos diretores de biblioteca:

"Acredito que nos falta pensar mais em metas, fazemos planejamentos para executar as atividades de rotina necessárias, mas o que buscamos para o futuro?" (Diretor de biblioteca).

"Poderíamos repensar nossos processos de trabalho, pois alguns são demorados e engessados. Acredito que possamos flexibilizar mais." (Diretor de biblioteca).

Os autores Jantz (2012a) e Finnemann (2014) também apontam a importância de maior relacionamento com outros setores da universidade e também com instituições ligadas a produção de informação, (editoras, meios de comunicação, etc.):

- Formação do bibliotecário: cursos de graduação mais focados em gestão, tecnologias e comunicação. Autores como Kumbhar (2012), Maceviciute (2014), Huff-Eibl, Voyles, Brewer (2011), Saunders (2012), Huvila et al. (2013), Vieira, Baptista e Cerveró, (2013) apontam a necessidade de novas habilidades e competências exigidas pelas transformações do ambiente externo, impactando na educação formal dos profissionais de biblioteca, contratação e avaliações de desempenho. Os diretores de biblioteca também apontaram que com as demandas dos usuários e 
mudanças tecnológicas, a formação do bibliotecário deveria ser atualizada:

"A formação do bibliotecário poderia ter mais sobre como usar recursos de edição digital, gestão de repositórios, manutenção de conteúdos online. Uma formação mais focada em tecnologia para produção e gestão de materiais digitais. Assim como precisamos de mais competências em gestão" (Diretor de biblioteca).

A literatura aponta que com as novas tecnologias e transformações na indústria editorial, as bibliotecas acadêmicas são instadas a mudar, porém esta mudança não deve ser somente no nível técnico e tecnológico, mas sim conceitual, repensando a abordagem e a forma como serão produzidos e geridos os serviços de modo que a biblioteca possa explorar melhor o potencial dos e-books e colocar-se como uma instituição atual e diferencial para seus usuários. Percebe-se nas entrevistas que os bibliotecários pontuaram as necessidades da biblioteca para oferecer melhores serviços aos seus usuários com a inclusão do e-book e todos os desafios que este traz, estas características se aproximam do conceito de biblioteca como produtora de informação. Assim, na pesquisa em campo se verifica que a mudança conceitual do serviço de biblioteca acadêmica se faz necessária.

Desde os anos 1990 e 2000 (LANCASTER, 1994; DRABENSTOTT; BURMAN, 1997; CUNHA, 2000; MARTINS, 2002) já se falava em mudanças na biblioteca acadêmica, porém ainda não se tinha clara a necessidade de mudar o conceito de serviço. As intensas e rápidas transformações tecnológicas deixaram claro que a tecnologia não veio apenas para automatizar e informatizar processos de trabalho e serviços da biblioteca, mas para auxiliá-la a desenvolver serviços em ambientes digitais e se comunicar com seus usuários neste meio, além disso, trouxe impactos na indústria de publicações e no mercado editorial. Ao analisar a literatura, percebe-se que os documentos digitais trouxeram mudanças às bibliotecas, porém o e-book é uma tecnologia que cristalizou de forma mais clara a necessidade de mudanças conceituais nas bibliotecas. O e-book trouxe uma série de problemas que demonstram que a biblioteca acadêmica na atual estrutura ainda não tem questões resolvidas como: a diversidade de formas de acesso, o controle do conteúdo do acervo pelas editoras, empréstimo digital, preservação digital, modelos de negócio, 
etc. Assim, atualmente a literatura discute transformações conceituais na biblioteca para então implementar mudanças na estrutura organizacional, gestão, tratamento da informação, atendimento ao usuário, capacitações, etc.

O fato da biblioteca estar projetando seus serviços em conceitos tradicionais que não refletem mais às necessidades e perfis de seus usuários e também das demandas e colocações do ambiente externo, torna mais difícil fazer com o que o uso de e-book seja maior e também consolidado nas bibliotecas universitárias. Não adiantará apenas aumentar o número de funcionários, comprar novos equipamentos de leitura, criar projetos e materiais de divulgação se não houver mudanças no conceito de produção de serviço e também na sistematização e continuidade de ações estratégicas. Situação que constatamos nas entrevistas: há bibliotecas que compraram e-readers, fizeram capacitações e divulgação diferenciada, porém ainda dentro dos moldes do conceito de biblioteca como difusora de informação. Os diretores relataram que estas ações foram infrutíferas para aumentar o uso de ebooks. Além de toda a problemática de questões externas, institucionais e comerciais que dificultam a gestão do e-book pelas bibliotecas, estas ao continuarem a adotar procedimentos de marketing, capacitação, atendimento ao usuário e tratamento da informação como sempre realizaram com os impressos colocam um obstáculo a mais para a inserção plena do e-book na biblioteca.

Apesar da necessidade de implantar um novo conceito de serviço de biblioteca, a literatura aponta algumas questões que são obstáculos para operacionalizar esta mudança conceitual:

- Incertezas e papéis indefinidos entre os profissionais:

"A natureza dos serviços de informação, ele também é de certa maneira
lógico, já que agora mais que nunca somos intermediários que realizamos
uma série de tarefas pouco visíveis e definidas, que as vezes são atribuídas
a outros profissionais como editores, gestores ou de computação"
(ARÉVALO, 2011 apud MODESTO, 2011).

- Falta de atenção da universidade:

"As bibliotecas podem ter pouca influência e representatividade na universidade, não tendo espaço relevante para serem ouvidas e atendidas suas demandas" (ORERA-ORERA, 2007, p. 335, tradução nossa). 
Orera-Orera (2007) indica que a biblioteca não pode ser considerada apenas como fornecedora de informação, em que o aluno só vai para buscar dados ou obras requisitadas pelo professor. A universidade colocando a biblioteca como parte estratégica no ensino, pesquisa e extensão por auxiliar sua comunidade a produzir pesquisa com seus recursos informacionais, profissionais qualificados, laboratórios e infraestrutura, sendo a biblioteca um espaço em que os alunos não mais vão apenas obter informação, mas desenvolver seus projetos de pesquisa. Assim, a biblioteca ganha mais voz em representações na universidade como conselhos, órgãos e congregações, podendo impactar a vida acadêmica da universidade, por isso é necessária ampliar sua representatividade e estar integrada a missão e objetivos da universidade.

- Falta de compreensão dos gestores quanto ao serviço da biblioteca para prover acesso à informação, não consideram as especificidades da biblioteca e assim não conseguem apoio de gestores para efetivar mudanças:

Quando a questão sobre futuro e a visibilidade das bibliotecas acadêmicas é levantada, bibliotecários expressam a preocupação de que não apenas os usuários, mas também o corpo docente e a administração compartilham o equívoco de que toda informação está gratuitamente disponível online. 0 problema de como educar seu corpo docente e sua administração acreditase ser uma questão crítica e em última análise determinará o futuro das bibliotecas acadêmicas. Alguns bibliotecários compartilharam suas abordagens em termos de trabalho e educação de seus administradores (HAN, 2012, p.169, tradução nossa).

Percebe-se que o uso dos e-books na biblioteca acadêmica não é somente uma questão de preferência ou não dos usuários, apesar de ter grande relevância em sua adoção, mas também em como a biblioteca se estrutura para oferecer o acesso aos e-books, como ela produz o serviço. Neste ponto, observamos na literatura que o conceito de biblioteca como difusora de informação não atende mais aos anseios da comunidade acadêmica e não acompanha as transformações tecnológicas e de mercado em velocidade hábil, pois não se estrutura e não tem o foco para isto.

A biblioteca no conceito de produtora de informação volta os seus serviços para que o usuário consiga produzir algo e não somente encontre informação, portanto, investe fortemente em capacitação e competência informacional de seus usuários, além de infraestrutura física com salas e laboratórios e equipamentos para 
seus usuários produzirem trabalhos, projetos, etc. A própria biblioteca é também produtora de conteúdos e tem o foco de oferecimento de serviços personalizados, para atender demandas específicas e não gerais de um grupo de usuários, portanto, sua equipe deve ser altamente qualificada, interdisciplinar e realizar monitoramento de ambiente externo e das necessidades dos usuários. Também há maior investimento de não só oferecimento de recursos digitais e automatização de serviços, mas de produção de serviços digitais, o usuário se utiliza dos serviços da biblioteca não apenas em ambiente físico, mas também online, como chats online, tutoriais online, capacitação online, etc.

Para gerenciar esta biblioteca no conceito de produtora de informação, possui sua base em planejamentos, faz prospecção de possíveis demandas futuras, portanto, projeta seus serviços para isto e não somente para organização de execução de demandas atuais.

\subsection{Gestão de e-books}

A falta de um plano de gestão de e-books dificulta a operacionalização da produção do serviço e também de visualização de possíveis lacunas e falhas na produção. Conforme constatado no estudo de caso, as bibliotecas da Unesp não possuem um modelo formalizado de gestão de e-books, porém nas entrevistas pudemos verificar que a Unesp segue um fluxo de gestão de e-books próximo ao de livros impressos também, conforme foi abordado no tópico 4. Resultados, reapresentando as etapas deste fluxo, temos:

1. Seleção

2. Aquisição

3. Tratamento da informação

4. Divulgação

5. Capacitação

6. Busca e acesso pelo usuário

7. Monitoramento do uso

Comparado a gestão de e-books na Unesp, no modelo de Vasileiou, Rowley e Hartley (2012) encontramos maior preocupação em questões de negociação no momento de aquisição e assinaturas e maior cuidado com revisão de metadados de 
títulos de e-books fornecidos pelas editoras, os quais serão utilizados para recuperálos na ferramenta de busca integrada da universidade pelo usuário.

O modelo de gestão de Vasileiou, Rowley e Hartley (2012a) ajuda a elencar as etapas importantes na gestão de e-books, contudo ainda falta a visualização de como estas etapas conversam, facilitando a gestão destas. A fim de suprir esta lacuna, buscamos na literatura de gestão de serviços, ferramentas de descrição de processos de produção de serviço, pois busca descrever como um sistema de produção de serviço funciona e suas partes estão correlacionadas (KINGMANBRUNDAGE; GEORGE; BOWEN, 1995, p. 21). Apresentamos a gestão de e-books na Unesp segundo o modelo de service blueprinting na figura 14 : 
Figura 14 - Gestão de e-books na Unesp em modelo service blueprinting

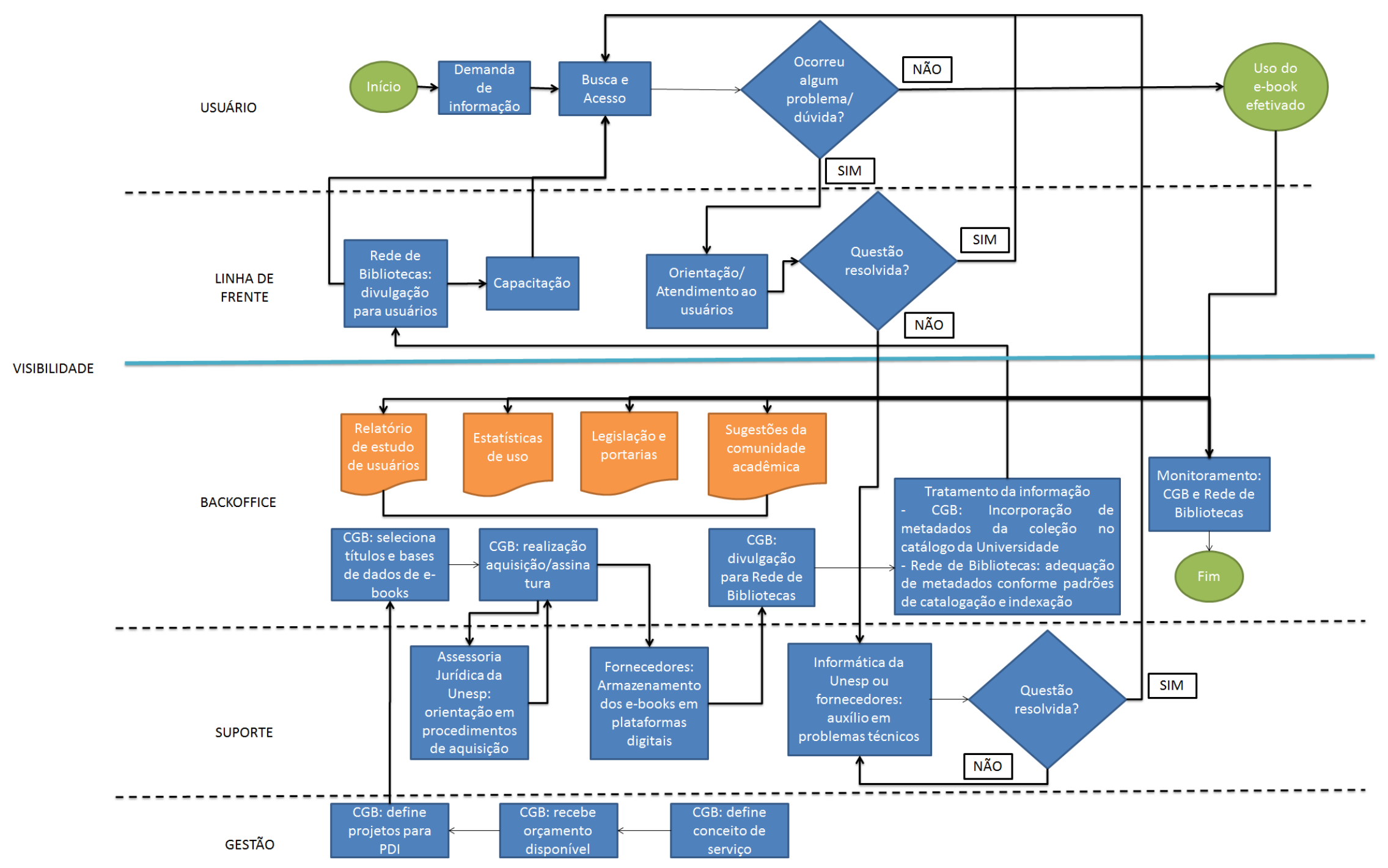

Fonte: autoria própria 
Observamos que apesar das etapas e do fluxo de gestão serem semelhantes ao impresso, há questões comerciais, legais, de tratamento da informação, armazenamento e monitoramento da coleção que são distintas dos impressos e que precisam ser apontadas como parte das atividades na gestão dos e-books. $\mathrm{Na}$ Unesp, observamos, que apesar de não existir um plano formal de gestão, há sim a preocupação e a atenção, principalmente, em questões comerciais e legais nas etapas de gestão que cabem a CGB. Contudo, nas etapas notavelmente de responsabilidade das bibliotecas da Rede, não detectamos em algumas bibliotecas a atenção em questões de tratamento de informação, divulgação e capacitação personalizada.

Nas entrevistas observamos um gargalo na dimensão suporte, em relação ao tempo de retorno de Assessoria Jurídica, fornecedores e Setor de informática, os quais nem sempre atendem às necessidades da CGB e da Rede de bibliotecas em tempo hábil. Quanto a atividades de backoffice, os diretores apontaram que na etapa de tratamento da informação não há adequação de todos os metadados de e-books, "poluindo" o catálogo da biblioteca. Ainda colocaram que falta autonomia para mudar alguns procedimentos técnicos de tratamento da informação e também a falta de revisão de procedimentos de catalogação de materiais digitais.

$\mathrm{Na}$ linha de frente constatamos que a falta de formalização de processos de trabalho com e-books nas bibliotecas da Unesp dificulta a sistematização e as ações contínuas em divulgação, capacitação e atendimento ao usuário. Esta é uma das dimensões da produção do serviço que necessita atenção e atualização contínua, pois se configura como uma das portas de entradas do usuário aos e-books, podendo cativá-los ao serviço.

Na dimensão do usuário, observa-se que a questão da busca e acesso está estreitamente vinculada à dimensão backoffice, pois é nesta dimensão que são definidos os contratos das modalidades de acesso e recursos de pesquisa disponíveis. Os diretores de biblioteca não podem modificar esta questão contratual, apenas auxiliar usuários na capacitação para uso, desenvolvimento de competências e esclarecimento de dúvidas.

É relevante realçar que o modelo de gestão de e-books auxilia as bibliotecas a incrementarem o uso de e-books em conjunto com a revisão do conceito de serviço da biblioteca. 
$\mathrm{Na}$ análise da literatura e no estudo de caso pudemos perceber alguns fatores que minimizam o uso do e-book em bibliotecas acadêmicas:

- Questões comerciais e de negociação com as editoras;

- Poder de exclusividade das editoras sobre títulos;

- Questões institucionais que dificultam a assinatura/aquisição de títulos;

- Falta de informações e dados estatísticos para gestão dos e-books;

- Falta de equipes capacitadas para compreender questões técnicas e comerciais dos e-books que afetam o uso;

- Falta de um programa de capacitação contínuo em bases de dados;

- Falta de um plano de divulgação: ações de marketing não coordenadas e não permanentes praticadas pelas bibliotecas;

- Falta de serviços, capacitações e divulgações personalizadas para usuários;

- Falta de planejamento e revisão de processos de trabalho nas equipes, resultando em falta de priorização de atividades;

- Falta de monitoramento do ambiente externo: novidades chegam pela demanda de usuários e não por estudos ou prospecção de interesses;

- Contratação de pessoas e gestão de pessoas: o processo de seleção não garante a contratação de pessoas em perfil e habilidades específicas para bibliotecas que trabalham em contextos dinâmicos como as bibliotecas universitárias. Além disso, os meios de avaliação, promoção não são adequados;

- Falta de um plano de gestão de e-books formalizado;

- Necessidade de revisão do conceito de serviço da biblioteca universitária.

Implementar um modelo de gestão de e-books em uma estrutura que não abarca características próprias de biblioteca do conceito de produtora de informação como: flexibilidade, personalização, capacitação, competência informacional, interdisciplinaridade, incentivo ao uso da biblioteca para produção e não apenas busca de informação irá diluir as ações do modelo de gestão, dificultando a operacionalização e minimizando os resultados de sua implementação. 


\section{CONSIDERAÇÕES FINAIS}

Com os e-books, houve uma ruptura no principal objeto de trabalho das bibliotecas: o livro impresso, por séculos foi o principal e mais utilizado suporte de documento fornecido pelas bibliotecas. Os seus serviços eram moldados em torno deste objeto, a indústria editorial e todas as empresas ligadas à publicação e à distribuição do livro impresso atuavam em um ambiente estável, pois o objeto livro não sofria alterações significativas. As bibliotecas tiveram que enfrentar mudanças apenas em resposta às alterações do contexto em que estivessem estabelecidas; contudo, com a expansão do e-book, percebeu-se com maior clareza a dificuldade de gestão das bibliotecas não apenas em termos desta adaptação, mas no que se refere à reação e ao posicionamento frente a mudanças de suportes de informação.

$\mathrm{O}$ estudo de caso realizado e a literatura revisada apontam que os e-books ressaltam a necessidade de revisão estrutural e conceitual de seus serviços. Os ebooks trazem diversos desafios às bibliotecas universitárias, como gestão de direitos autorais, preservação digital, capacitação, comunicação online, desenvolvimento de coleções, modelos de negócio, etc. A gestão de e-books ultrapassa questões tecnológicas, impactando mercado, marketing, comercialização, direitos autorais, autenticidade de conteúdo, entre outras. Como se propunha com o objetivo específico 1, todos os componentes da cadeia produtiva do livro precisam repensar estratégias e estruturas, pois o e-book traz impactos em menor ou maior grau a todos eles:

- A relação entre autor-editor: tiragens, reimpressões e edições esgotadas não fazem mais parte deste universo. Os contratos das editoras com autores não podem mais estar vinculados ao esgotamento da edição;

- Self-publishing: o autor não precisa mais de uma editora para publicar seu livro, podendo realizar este processo de forma autônoma;

- Movimentos de acesso aberto: há maior adesão por parte da comunidade científica à prática de colocar suas pesquisas em plataformas que não cobram taxas, assinaturas ou pagamento de licenças; 
- A biblioteca tem o acesso, mas não a posse do livro: o livro eletrônico geralmente fica no servidor ou na plataforma do fornecedor (mesmo em caso de aquisição perpétua), eventualmente podendo ocorrer cobrança de taxa de manutenção das plataformas para que a biblioteca continue a ter acesso ao título;

- Garantia de acesso ao livro: depende do contrato com o fornecedor, o qual pode deter o direito de interromper o acesso ao título ou trocá-lo por outro (caso o fornecedor deixe de trabalhar com determinada editora);

- Aquisição de livros: editoras e fornecedores de bases de dados de ebooks apresentam modelos de aquisição que interferem no acesso e uso;

- Edição: por ser um recurso em ambiente digital, a formatação do ebook é diferente de um impresso, podendo ser incrementada com meios audiovisuais, dispositivos de busca, marcação, hiperlinks, etc;

- Autenticidade e preservação digital: mesmo em obras que estão em domínio público e não apresentam restrições de distribuição são necessários recursos que garantam que ela não sofreu alterações, assim como cuidados para manter o acesso à obra e não cair em risco de obsolescência tecnológica;

- Diversidade de formatos e dispositivos: a literatura apresenta a diversidade de formatos de arquivos e suas incompatibilidades com softwares;

- Comercialização: a compra de um produto digital em ambiente digital demanda cuidados diferenciados de segurança e acesso ao produto.

A configuração da rede de produção do e-book posiciona a biblioteca em situação de maior vulnerabilidade a alterações de mercado e tecnologias do que com a cadeia produtiva do livro impresso, em que sua presença estava apenas no final do processo produtivo, porém na rede, sua relação com os demais componentes é maior, sendo estes agentes e não apenas executores de uma cadeia de produção de modo que todos os componentes afetam a dinâmica da produção de e-books. No estudo de caso e na revisão de literatura, observamos que há quatro 
grandes tipos de problemas que afetam a gestão de e-books, e consequentemente 0 uso de e-books nas bibliotecas acadêmicas, apresentados no quadro 10:

Quadro 10 - Principais problemas na gestão de e-books

\begin{tabular}{|c|l|}
\hline \multicolumn{2}{|c|}{ Questões } \\
\hline Comerciais & $\begin{array}{l}\text { Falta de informação de editoras e fornecedores, modelos } \\
\text { de negócio e condições contratuais que afetam a forma } \\
\text { de acesso e uso de e-books, sendo que a biblioteca } \\
\text { universitária, sem estar envolvida em um consórcio de } \\
\text { bibliotecas, tem pouco poder de negociação. }\end{array}$ \\
\hline Institucionais & $\begin{array}{l}\text { Regras de compra, cumprimento de prazos e burocracias } \\
\text { da universidade que dificultam a compra, assinatura ou } \\
\text { renovação de bases de dados. }\end{array}$ \\
\hline organizacional & $\begin{array}{l}\text { Falta de autonomia para rotinas de trabalho e } \\
\text { procedimentos técnicos, falta de planejamento, falta de } \\
\text { capacitação contínua, políticas de gestão de pessoas. }\end{array}$ \\
\hline Conceituais & $\begin{array}{l}\text { Dificuldade de mudar e implementar mudanças nas } \\
\text { bibliotecas devido à concepção do serviço de biblioteca } \\
\text { não condizer mais com as exigências dos usuários e as } \\
\text { transformações do ambiente externo. Contatou-se que as } \\
\text { necessidades apontadas por diretores de biblioteca iam } \\
\text { ao encontro de conceitos presentes no modelo de } \\
\text { biblioteca do tipo produtora de informação. }\end{array}$ \\
\hline
\end{tabular}

Fonte: autoria própria.

Analisar os e-books nas bibliotecas a partir da perspectiva da Produção de Serviços trouxe um novo olhar à problemática, não focada em usabilidade, questões técnicas, do usuário ou de alguma atividade específica da biblioteca, já existentes no Brasil, mas sim em produção e gestão de serviço de fornecimento de e-books, sendo esta uma contribuição da presente pesquisa, pois acrescentou mais uma abordagem de estudo de e-books. Constatou-se que os problemas na gestão que foram detectados por meio do mapeamento da produção do serviço com o esquema 
de service blueprinting estão diretamente relacionados com o baixo uso de e-books nas bibliotecas universitárias, atendendo ao objetivo específico 2.

Acrescenta-se que a esquematização das etapas da gestão de e-books reunidas com questões e desafios apontados pela literatura, apresentados no quadro 7 - roteiro das entrevistas semiestruturadas, e sua relação com o novo modelo conceitual de biblioteca universitária foi outra contribuição desta dissertação. Procuramos explorar a pergunta de pesquisa apontando os desafios e problemas na produção e gestão de e-books, porém tais problemas estão relacionados com questões conceituais; abordou-se que a solução de questões de gestão não seria eficaz na ausência de uma reformulação conceitual de serviço de biblioteca, atingindo a proposta do objetivo específico 3. Conforme visto na literatura, o conceito de serviço que mais se aproxima das necessidades dos usuários e do contexto de mudanças vivido pelas bibliotecas universitárias é o de biblioteca como produtora de informação. A análise de conceitos de serviço de bibliotecas a partir dos conceito de serviço de Johnston e Clark resultou no quadro 4 - Conceito de serviço de biblioteca universitária: difusora versus produtora de informação, espera-se que a esquematização destes conceitos junto com as discussões de gestão de e-books de Wilkins (2007), Procópio (2010), Oliveira (2012), Vasileiou, Rowley e Hartley (2012a) e Walters (2013), auxiliem outros pesquisadores e gerem mais questões de pesquisa.

Espera-se que a dissertação dê insumos e novas possibilidades ao estudo de livros eletrônicos: quanto ao próprio e-book: suas especificidades técnicas intrínsecas e as incertezas que o permeiam por ser uma inovação; aprofundamento nas questões do mercado editorial e seus agentes; questões de usabilidade de bases de dados e de dispositivos de leitura; ater-se a uma das etapas de gestão de e-books específicas, as quais necessitam de revisão e aprofundamento, pois o foco desta dissertação foi apenas apresentá-las e observar o relacionamento entre elas, contudo há diferentes desafios em cada etapa que necessitam de estudo e por fim, estudos de usuários: novos perfis, necessidades, gostos e preferências relacionados às atividades acadêmicas que docentes e discentes precisam desempenhar. 


\section{REFERÊNCIAS}

AAP, BISG - ASSOCIATION OF AMERICAN PUBLISHERS, BOOK INDUSTRY STUDY GROUP. BookStats. New York: AAP; BISG, 2012.

AGÊNCIA BRASIL. Apesar de crescimento de 350\% nas vendas, livros digitais não chegam a $1 \%$ do faturamento das editoras. Agência Brasil. Set. 2013. Disponível em: <http://memoria.ebc.com.br/agenciabrasil/noticia/2013-09-05/apesar-decrescimento-de-350-nas-vendas-livros-digitais-nao-chegam-1-do-faturamento-daseditoras>. Acesso em: 04 out. 2013

AKEROYD, J. The future of academic libraries. Aslib Proceedings, v. 53, n. 3, p. 79-84, 2001.

ALA - American Library Association. E-book business models for public libraries. 2012. Disponível em: <http://connect.ala.org/files/80755/E-

bookBusinessModelsPublicLibs.pdf>. Acesso em: 01 fev. 2013.

ALA - American Library Association. E-book business models: a scorecard for public libraries. 2013. Disponível em: <http://www.districtdispatch.org/wpcontent/uploads/2013/01/E-book_Scorecard.pdf>. Acesso em: 01 fev. 2013.

AL-ANSARI, H. A. Improving organizational structure for an electronic environment: a case analysis of Kuwait University libraries. Library Review, v. 48, n. 3, p. 131-139, 1999.

ALMEIDA, L. J. C. de. O livro digital no mundo editorial e a evolução histórica do copyright e das estratégias de apropriação de lucro. 2012. 354 f. Dissertação (Mestrado em Administração) - Faculdade de Economia, Administração e Contabilidade, Universidade de São Paulo, 2012.

AMIN, N. M.; GERBIC, P. Exploring the use of digital library services in a blended learning environment: a malaysian higher education perspective. In: International Conferences of Education, Research and Innovation. 3., 2010. Madrid.

Proceedings..., p. 1782-1792.

ANASTASIOU, L. das G. C.; ALVES, L. P. (Orgs.). Processos de ensinagem na universidade: pressupostos para as estratégias de trabalho em aula. 5. ed. Joinville: Univille, 2005.

ANL - Associação Nacional de Livrarias. Pesquisa sobre a produção e vendas do setor livreiro de 2011 indica a livraria como sendo o principal canal de vendas de livro. 2012. Disponível em:

<http://anl.org.br/web/pdf/pesquisa_cblsnel_2012.pdf>. Acesso em: 11 fev. 2013.

APCR - ASSOCIAÇÃO PAULISTA DE CONSERVADORES RESTAURADORES DE BENS CULTURAIS. Código de ética do conservador-restaurador. 2005.

Disponível em: <http://www.apcr-sp.com.br/quemsomos/codetica.php>. Acesso em: 05 nov. 2013. 
ARRUDA, S. M. de; CHAGAS, J. Glossário de biblioteconomia e ciências afins. Florianópolis: Cidade Futura, 2002.

BACALGINI, B.; SILVA, M. T. da. Rede de produção de livros eletrônicos e bibliotecas universitárias: estudo de caso de bases de dados utilizadas pela USP, Unesp e Unicamp. In: XXXIII ENCONTRO NACIONAL DE ENGENHARIA DE PRODUÇÃO. 31., 2013. Salvador. Anais... Salvador: ENEGEP, 2013.

BACALGINI, B.; SILVA, M. T. da. Redefinição do conceito de serviço de bibliotecas universitárias perante as mudanças tecnológicas. Espacios, v. 36, n. 12, 2015.

BENGHOZI, P. J.; SALVADOR, E. R\&D in creative industries: some lessons from the book publishing sector. Tafterjournal, n. 64. 2013.

BITNER, M. J.; OSTROM, A. L.; MORGAN, F. N. Service blueprinting: a practical technique for service innovation. Arizona State University, 2007. Disponível em: $<$ http://files.g51studio.com/parsons/ServiceBlueprinting.pdf>. Acesso em: 20 set. 2015.

BOWEN, J.; FORD, R.C. Managing service organizations: does having a "thing" make a difference?. Journal of Management, v.28, n. 3, p. 447-469, 2002.

BRATANEK, L. A. Case study of e-book use in an academic library: a communication perspective. 2013. 135 f. Dissertação (Mestrado em Comunicação). Faculdade de Artes, Universidade de Ottawa, Ottawa, Canada, 2013.

CASTRO FILHO, C. M. de. O novo modelo de biblioteca universitária: Centro de Recursos para el Aprendizaje y la Investigación (CRAI): serviços, características e organização. In: XV Seminário Nacional de Bibliotecas Universitárias. 15., 2008, Campinas. Anais... Campinas: Unicamp: 2008, p. 2-14.

CASTRO FILHO, C. M. de.; VERGUEIRO, W. Convergências e divergências do modelo europeu do Centro de Recursos para el Aprendizaje y la Investigación (CRAI) em relação às bibliotecas universitárias brasileiras. Bibliotecas Universitárias, v. 1, n. 1, jan./jun. 2011.

CBL - Câmara Brasileira do Livro. Produção e vendas do setor editorial brasileiro. São Paulo: CBL/SNEL, 2012.

CORDÓN-GARCÍA, J. A.; GÓMEZ-DÍAZ, R.; ALONSO-ARÉVALO, J. Libros electrónicos: oferta comercial y redes. El profesional de la información, v. 20, n. 02, p. 149-158, 2011.

CUBITT, S. The open library. The Book Seller. 2013. Disponível em:

<http://www.thebookseller.com/blogs/open-library.html>. Acesso em: 24 jul. 2013.

CUNHA. Construindo o futuro: a biblioteca universitária brasileira em 2010. Ciência da Informação, v. 29, n.1, p. 71- 89, 2000. 
CUNHA, M. B. da. A biblioteca universitária na encruzilhada. DataGramaZero, v.11, n. $6,2010$.

CUNHA, M. B. da; CAVALCANTI, C. R. de O. Dicionário de Biblioteconomia e Arquivologia. Brasília: Briquet de Lemos, 2008.

DIAS, M. M. K.; PIRES, D. Usos e usuários da informação. São Carlos: EDUFSCar, 2004. (Série Apontamentos).

DIAS, R. C.; WEBER, C. Preservação Digital: uma proposta para Bibliotecas Universitárias. In: XXV Congresso Brasileiro de Biblioteconomia, Documentação e Ciência da Informação. 25., 2013, Florianópolis. Anais... Florianópolis: FEBAB, 2013.

DOMÍNGUEZ AROCA, M. I. La biblioteca universitaria ante el nuevo modelo de aprendizaje: docentes y bibliotecários, aprendamos juntos porque trabajamos juntos. Revista de Educación a Distancia, ano 4, n. 3, p. 1-15, 2005.

DRABENSTOTT, K. M.; BURMAN, C. M. Revisão analítica da biblioteca do futuro. Ciência da Informação, v. 26, n. 2, p. 1-15, 1997A.

DUARTE, A. B. S.; LOPES, A. de Q.; ANTUNES, M. L. A.; FERREIRA, E. G. A.; PEREIRA, A. L. Livro eletrônico: o que dizem os bibliotecários da Universidade Federal de Minas Gerais. In: XXV Congresso Brasileiro de Biblioteconomia, Documentação e Ciência da Informação. 25., 2013, Florianópolis. Anais... Florianópolis: FEBAB, 2013.

DUDZIAK, E.A. Information Literacy: princípios, filosofia e prática. Ciência da Informação, Brasília, v. 32, n. 1, p. 23-35, jan./abr. 2003.

EISENHARDT, K. M. Building theories from case study research. Academy of Management Review, v. 14, n. 4, p. 532-550, 1989.

\section{FERREIRA JÚNIOR, S. C. Servitização no mercado brasileiro de livros} didáticos: implicações organizacionais para as editoras. 2011. 168 f. Dissertação (Mestrado em Engenharia de Produção) - Escola Politécnica, Universidade de São Paulo, São Paulo, 2011.

FINNEMANN, N. O. Research libraries and the internet: On the transformative dynamic between institutions and digital. Journal of Documentation, v. 70, n. 2, p. 202-220, 2014.

FUJITA, M. S. L. Aspectos evolutivos das bibliotecas universitárias em ambiente digital na perspectiva da rede de bibliotecas da UNESP. Informação \& Sociedade: Estudos, v. 15, n. 2, p. 97-112, 2005.

FURNIVAL, A. C. ; GRACIOSO, L. de S. M-libraries e information commons: novos espaços, novas práticas. Geminis, ano 2 , n. 1, p. 86-105, 2011. 
FURTADO, J. A. El Papel y el píxel: de lo impreso a lo digital: continuidades y transformaciones. Gijón: Trea, 2007. (Biblioteconomía y administración cultural; v. 163).

GARROD, P. E-books: are they the interlibrary lending model of the future? Interlending \& Document Supply, v. 32, n. 4, p. 227-233, 2004.

GIL, A. C. Métodos e técnicas de pesquisa social. 6. ed. São Paulo: Atlas, 2008.

GOFFIN, K.; MITCHELL, R. Innovation management: strategy and implementation using Pentathlon Framework. Houndmills: Palgrave Macmillan, 2010.

GRADMANN, S. From containers to content context: the changing role of libraries in eScience and eScholarship, Journal of Documentation, v. 70, n. 2, p. 241-260, 2014.

GRAU, I.; ODDONE, N.; DOURADO, S. E-books, livros digitais ou livros eletrônicos? Um estudo terminológico. In: XIV ENCONTRO NACIONAL DE PESQUISA EM CIÊNCIA DA INFORMAÇÃO. 14. , 2013, Florianópolis. Anais... Florianópolis: ENANCIB, 2013.

GROGAN, D. A prática do serviço de referência. Brasília, DF: Brinquet de Lemos Livros, 1995.

GUSTIN LACRUZ, M. del C. Bibliotecas digitales y sociedad de la información. Scire, v. 4, n. 2, p. 47-62, 1998.

HAN, N. Managing a 21st-century library collection. The Serials Librarian, v. 63, p. 158-169, 2012.

HERTHER, N. K. The e-book industry today: a bumpy road becomes an evolutionary path to market maturity, The Electronic Library, v. 23, n. 01, p. 45-53, 2005.

HUFF-EIBL, R.; VOYLES, J. F.; BREWER, M. M. Competency-based hiring, job description, and performance goals: the value of an integrated system, Journal of Library Administration, v. 51, n. 7-8, p. 673-691, 2011.

HUVILA, T.; HOLMBERG, K.; KRONQVIST-BERG, M.; NIVAKOSKI, O.; WIDÉN, G. What is librarian 2.0: new competencies or interactive relations? A library professional viewpoint, Journal of Librarianship and Information Science, v. 45, n. 3, p. 198-205, 2013.

IDOETA, P. A. Empréstimo de livros digitais opõe bibliotecas e editoras. BBC Brasil, 25 jan. 2013. Disponível em:

<http://www.bbc.co.uk/portuguese/noticias/2013/01/130122_bibliotecas_3_ebooks_p ai.shtml>. Acesso em: 14 fev. 2013.

INSTITUTO PRÓ-LIVRO. Retratos da leitura no Brasil. São Paulo: Instituto PróLivro, 2012. 
IFLA - INTERNATIONAL FEDERATION OF LIBRARY ASSOCIATIONS AND INSTITUTIONS (IFLA). Guidelines on information literacy for lifelong learning. Boca del Río, Veracruz: IFLA, 2006. Disponível em:

$<$ http://www.ifla.org/files/information-literacy/publications/ifla-guidelines-en.pdf>. Acesso em: 01 jun. 2015.

IFLA - INTERNATIONAL FEDERATION OF LIBRARY ASSOCIATIONS AND INSTITUTIONS (IFLA). Glossary of terms and abbreviations and useful links. 2013. Disponível em: <http://www.ifla.org/node/7666>. Acesso em: 03 jan. 2016.

JANTZ, R. C. A framework for studying organizational innovation in research libraries, College \& Research Libraries, v. 73, n. 6, p. 525-540, 2012a.

JANTZ, R. C. Innovation in academic libraries: an analysis of university librarians perspectives. Library \& Information Science Research, v. 34, p.3-12, 2012b.

JIANG, Y.; KATSAMAKAS, E. The impact of e-book technology on book retailing. In: $43^{\text {rd }}$ HAWAII INTERNATIONAL CONFERENCE ON SYSTEM SCIENCES, 43., 2010. Proceedings... s.l.: IEEE, p. 1-8.

JOHNSON, G.; SCHOLES, K.; WHITTINGTON, R. Exploring corporate strategy. 8. ed. Harlow: Pearson Education, 2008.

JOHNSTON, R; CLARK, G. Administração de operações de serviço. São Paulo: Atlas, 2002.

JOINT INFORMATION SYSTEMS COMMITTEE - JISC. JISC National E-books Observatory Project: Final Report. 2009. Disponível em: <www.jiscebooksproject.org/reports/finalreport>. Acesso em: 25 abr. 2014.

KINGMAN-BRUNDAGE, J.; GEORGE, W. R.; BOWEN, D. E. Service logic: achieving service system integration. International Journal of Service Industry Management, v. 6, n. 4, p. 777-795, 1995.

KROLL, S.; FORSMAN, R. A slice of research life: information support for research in the United States. Dublin, Ohio: OCLC. 2010. Disponível em:

<http://www.oclc.org/research/publications/library/2010/2010-15.pdf>. Acesso em: 27 fev. 2015.

KUHLTHAU, C. C. Seeking meaning: a process approach to library and information services. 2. ed. Englewood : Libraries Unlimited, 2004.

KUMBHAR, R. E-books: review of research and writing during 2010, The Electronic Library, v. 30, n. 6, p. 777-795, 2012.

LANCASTER, F. W. Ameaça ou oportunidade? O futuro dos serviços de biblioteca à luz das inovações tecnológicas. Revista Escola Biblioteconomia UFMG, v. 23, n.1, p. 7-27, 1994. 
LUH-WANG, W.; HUI-YI, H. Study on the strategy of Taiwan's digital publishing industry. In: $3^{\text {rd }}$ INTERNATIONAL CONFERENCE ON INFORMATION SCIENCES AND INTERACTION SCIENCES, 3., 2010. Proceedings... Chengdu: IEEE, 2010.

MACEVICIUTE, E. Research libraries in a modern environment. Journal of Documentation, v. 70, n. 2, p. 282-302, 2014.

MACHADO, R. das N.; NOVAES, M. S. F.; SANTOS, A. H. dos. Biblioteca do futuro na percepção de profissionais da informação. Transinformação, v. 11, n. 3, p. 215222,1999 .

MARRA, P dos S. C. O papel das bibliotecas universitárias na comunicação científica: um estudo sobre os repositórios institucionais. Florianópolis, Encontros Bibli: revista eletrônica de biblioteconomia e ciência da informação, v. 17, n. esp. 2, p. 174-194, 2012.

MARTINS, R. A. Abordagens quantitativa e qualitativa. In: MIGUEL, P. A. C. (Coord). Metodologia de pesquisa em engenharia de produção. 2. ed. Rio de Janeiro: Elsevier, 2012, p.47-63.

MARTINS, R. D. Perspectiva para uma biblioteca no futuro: utopia ou realidade. Informação e Sociedade: estudos, v. 12, n.1, p. 149-172, 2002.

MASETTO, M. T. Competência pedagógica do professor universitário. São Paulo: Summus Editorial, 2012.

MCALLISTER, D.; MCALLISTER, N.; VIVIAN, S. The impact of digital books upon print publishing. In: INTERNATIONAL SYMPOSIUM ON TECHNOLOGY AND SOCIETY, 2002. Raleigh, p. 150-154. Proceedings... s.I.: IEEE.

MICHALAK, S. C. This change everything: transforming the academic library, Journal of Library Administration, v. 52, p. 411-423, 2012.

MIGUEL, P. A. C. (Coord). Metodologia de pesquisa em engenharia de produção. Rio de Janeiro: Elsevier, 2010.

MODESTO, J. F. Biblioteca universitária: evolução do conceito na ambiência das redes sociais. [Slides]. 2011. Taubaté: Universidade de Taubaté. Disponível em: <http://pt.slideshare.net/Modesto/biblioteca-universitria-a-evoluo-do-conceito-naambincia-das-redes-sociais>. Acesso em: 27 fev. 2015.

MORAES, A. C. Entre livros e-books: a apropriação de textos eletrônicos por estudantes ingressados na Universidade Federal do Rio Grande do Sul em 2011. 2012. 199 f. Dissertação (Mestrado em Comunicação e Informação) - Faculdade de Biblioteconomia e Documentação, Universidade Federal do Rio Grande do Sul, Porto Alegre, 2012.

MUNDT, M.; MEDAILLE, A. New medias, new challenges: the library and multimedia literacy in higher education. The International Journal of Technology, Knowledge and Society, v. 7, n. 2, p. 49-60, 2011. 
OLIVEIRA, D. A. O papel do editor gaúcho frente à produção e comercialização dos livros digitais. In: 3 을 CONGRESSO INTERNACIONAL CBL DO LIVRO DIGITAL, 3., 2012, São Paulo. Anais... Disponível em: < http://www.congressodolivrodigital.com.br/blog/wp-content/TC-danusa-almeida-deoliveira-100412235559.doc>. Acesso em: 01 fev. 2013.

ORERA-ORERA, L. La biblioteca universitaria ante el nuevo modelo social y educativo, El profesional de la información, v. 16, n. 4, p. 329-337, 2007.

PEREIRA, M. A. C. Competências para o ensino e a pesquisa: um survey com docentes de engenharia química. 2007. 289 f. Tese (Doutorado em Engenharia de Produção) - Escola Politécnica, Universidade de São Paulo, São Paulo, 2007.

PERKMANN, M. et al. Academic engagement and commercialisation: a review of the literature on university-industry relations, Research Policy, v. 42, p. 423-442, 2013.

PINSKY, D. O uso do livro eletrônico no ensino superior sob a ótica dos professores universitários e profissionais de editoras. 2009. $141 \mathrm{f}$. Dissertação (Mestrado em Administração de Empresas) - Faculdade de Economia, Administração e Contabilidade, Universidade de São Paulo, São Paulo, 2009.

PINKSY, L. Do papel ao digital: como as novas tecnologias desafiam a função do editor de livros de história. 2013. 178 f. Dissertação (Mestrado em Ciências da Comunicação) - Escola de Comunicações e Artes, Universidade de São Paulo, São Paulo, 2013.

PROCÓPIO, E. O livro na era digital: o mercado editorial e as mídias digitais. São Paulo: Giz Editorial, 2010.

RAO, S. S. Electronic books: a review and evaluation, Library Hi Tech, v. 21, n. 01, p. 85-93, 2003.

REITZ, J. M. Online Dictionary for Library and Information Science. 2014.

Disponível em: <http://www.abc-clio.com/ODLIS/odlis_e.aspx>. Acesso em 03 jan. 2016.

RIBEIRO, R. M. R. A tecnologia da informação e comunicação (TIC): fator condicionante da inovação em bibliotecas universitárias. Revista Digital de Biblioteconomia e Ciência da Informação, v. 9, n. 2, p. 41-48, 2012.

RÜDIGER WISCHENBART. Global eBook: a report on market trends and developments. s.l.: Rüdiger Wischenbart Content and Consulting, 2014. Disponível em: <http://www.global-ebook.com>. Acesso em: 01 abr. 2014.

SANTOS, G. C.; RIBEIRO, C. M. Acrônimos, siglas e termos técnicos: arquivística, biblioteconomia, documentação, informática.

Campinas: Átomo, 2003. 
SAUNDERS, L. Identifying Core Reference Competencies from an Employers' Perspective: Implications for Instruction, College \& Research Libraries, v. 73, n. 4, p. 390-404, 2012.

SENNYEY, P.; ROSS, L.; MILLS, C. Exploring the future of academic libraries: a definitional approach. The Journal of Academic Librarianship, v. 35, n. 3, p. 252259, 2009.

SERRA, L. G. Livro digital e bibliotecas. São Paulo: FGV, 2014. (Série Sociedade e Cultura ; v. 36).

SEVERINO, A. J. Educação e universidade: conhecimento e construção da cidadania. Interface: Comunic., Saúde, Educ., v. 6, n. 10, p. 117-124, fev. 2002.

SEVERINO, A. J. Ensino e pesquisa na docência universitária: caminhos para a integração. São Paulo: Pró-Reitoria de Graduação, 2008 (Cadernos de Pedagogia Universitária ; v. 3).

SHAW, W. The forgotten e-book market. Information Today, v. 27, n. 6, 2010.

SILVA, M. H. F. X. da; SILVA, R. J. da; MATIAS, T. L. Preservação digital de periódicos eletrônicos: projeto PORTICO. In: XVIII Seminário Nacional de Bibliotecas Universitárias. 18., 2014, Belo Horizonte. Anais...Belo Horizonte: UFMG, 2014.

THOMPSON, J. B. Books in the digital age: the transformation of academic and higher education publishing in Britain and United States. Cambridge: Polity Press, 2005.

TONKERY, D. Publishing industry sales: good news for publishers, not so much for libraries?. Searcher, v. 19, n. 09, 2011.

TRAVICA, B. Organizational aspects of the virtual library: a survey of academic libraries. Library \& Information Science Research, v. 21, n. 2, p. 173-203, 1999.

UNB-FCI - UNIVERSIDADE DE BRASÍLIA. FACULDADE DE CIÊNCIA DA INFORMAÇÃO. Glossário da FCI. 2015. Disponível em:

<www.fci.unb.br/index.php/glossario.html>. Acesso em 03 jan. 2016.

UNESP - Universidade Estadual Paulista "Júlio de Mesquista Filho". Sobre a Unesp: perfil. 2015a. Disponível em: <

http://www.unesp.br/portal\#!/apresentacao/perfil>. Acesso em: 14 nov. 2015.

UNESP - Universidade Estadual Paulista "Júlio de Mesquista Filho". Sobre a CGB. 2015b. Disponível em: < http://www.unesp.br/portal\#!/cgb/cgb2350/sobre-a-cgb>. Acesso em: 14 nov. 2015.

UNESCO - UNITED NATIONS EDUCATIONAL, SCIENTIFIC AND CULTURAL ORGANIZATION. Understanding information literacy: a primer. Paris: UNESCO, 2007. Disponível em: 
$<$ http://unesdoc.unesco.org/images/0015/001570/157020e.pdf>. Acesso em: 05. jun. 2013.

VASILEIOU, M.; ROWLEY, J. HARTLEY, R. The e-book management framework: the management of e-books in academic libraries and its challenges. Library \& Information Science, v. 34, p. 282-291, 2012a.

VASILEIOU, M.; HARTLEY, R.; ROWLEY, J. Choosing e-book: a perspective from academic libraries. Online Information Review, v. 36, n. 1, p. 21-39, $2012 b$.

VASSILIOU, M.; ROWLEY, J. Progressing the definition of "e-book". Library Hi Tech, v. 26, n. 3, p. 355-368, 2008.

VELASCO, J. O. O uso do livro eletrônico na prática científica. 2008. 188 f. Dissertação (Mestrado em Ciência da Informação) - Instituto de Ciência da Informação, Universidade Federal da Bahia, Salvador, 2008.

VERGUEIRO, W. Desenvolvimento de coleções. São Paulo: Polis/APB, 1989.

VIEIRA, D. V; BAPTISTA, S. G.; CERVERÓ, A. C. As competências profissionais do bibliotecário 2.0 no espaço da biblioteca universitária: discussão da prática, Informação \& Sociedade: Estudos, v. 23, n. 2, p. 45-58, 2013.

VOSS, C.; TSIKRITSIS, N.; FROHLICH, M. Case research in operations management. International Journal of Operations \& Production Management, v. 22, n. 2, p. 195-219, 2002.

WALTERS, W. H. E-books in academic libraries: challenges for acquisition and collection management. Portal: Libraries and the Academy, v. 13, n. 2, p. 187-211, 2013.

WILD, R. Concepts of operations management. Chichester: John Wiley \& Sons, 1977.

WILKINS, V. Managing e-books at the University of Derby: a case study. Program: Electronic Library and Information Systems, v. 41, n. 3, p. 238-251, 2007.

YIN, R. Estudo de Caso: Planejamento e Métodos. 4. ed. Porto Alegre: Bookman, 2010.

ZARIFIAN, P. Valor, organização e competência na produção de serviço: esboço de um modelo de produção de serviço. In: Salerno, M. S. Relação de serviço:

produção e avaliação. São Paulo: SENAC, 2001. (Série Trabalho e Sociedade). 


\section{GLOSSÁRIO}

Catálogação na fonte: "O objetivo do programa é prover dados bibliográficos para os novos livros antes mesmo de sua publicação, o que, entretanto, depende muito da cooperação voluntária dos editores. Os registros são compilados a partir de informação fornecida pelos editores em uma planilha de dados padrão. $O$ registro também aparece no próprio livro, geralmente no verso da folha de rosto" [mais conhecido como ficha catalográfica]. (IFLA, 2013, sem paginação, tradução nossa).

Competência informacional: "o processo contínuo de internalização de fundamentos conceituais, atitudinais e de habilidades necessário à compreensão e interação permanente com o universo informacional e sua dinâmica, de modo a proporcionar um aprendizado ao longo da vida" (DUDZIAK, 2003, p. 28).

E-commerce: "Consiste em, basicamente, realizar transações de compra on-line, executando os processos de escolha, ordem de compra e pagamento em forma eletrônica" (UNB-FCl, 2015, sem paginação).

E-reader: "Um dispositivo eletrônico, leve, portátil, alimentado a bateria, similar em sua forma a um tablet, projetado principalmente para a leitura de livros e periódicos baixados para o aparelho em forma digital (por exemplo: o Kindle da Amazon.com). Apesar de tablets apresentarem melhor performance, leitores de e-books possuem legibilidade superior, adquirida graça ao uso de tecnologia de display de papel eletrônico. Alguns leitores de e-book vêm com um dicionário interno, Wi-fi integrado, sintetizador de voz para texto e um navegador Web. O preço varia de acordo com a capacidade de armazenamento e as características especiais. Leitores de ebooks compatíveis com bibliotecas, que podem ser utilizados para emprestarebooks de bibliotecas públicas, normalmente suportam EPUB e/ou arquivos em formato PDF com gerenciamento de direitos digitais (DRM)". (REITZ, 2014, tradução nossa).

Indexação: "Atividade de designer o conteúdo de cada document com termos apropriados (cabeçalhos) de nomes, locais, assuntos, etc, a fim de facilitar a recuperação". (REITZ, 2014, tradução nossa).

Repositório Institucional (RI): "Um conjunto de serviços oferecidos por uma universidade ou grupo de universidades aos membros de sua comunidade para 0 gerenciamento e disseminação de materiais acadêmicos em formato digital criados pela instituição ou pelos membros de sua comunidade, como e-prints, relatórios técnicos, teses e dissertações, bases de dados e materiais de ensino. [...] As Rls são uma parte de um esforço crescente para reformar a comunicação científica e quebrar o monopólio dos editores de periódicos através da reafirmação do controle institucional sobre os resultados da comunidade científica. Um RI pode servir, também, como um indicador do âmbito e extensão das atividades de pesquisa da universidade". (REITZ, 2014, sem paginação, tradução nossa). 
Serviço de Descoberta: "Uma interface única provedora de acesso a múltiplos recursos de informação (catálogos, e-books e acervos de periódicos eletrônicos dos editores, bases de dados de assinaturas, acervos de arquivos) sobre os quais a biblioteca possui direitos. Sistemas de descobertas usam indexadores de tópicos e metadados já consolidados. Geralmente as duplicatas dos resultados da busca são removidas e os resultados são ordenados por relevância [...]". (REITZ, 2014, sem paginação, tradução nossa).

Vocabulário Controlado: "Uma lista pré-estabelecida de termos preferenciais à qual um catalogador ou indexador devem se referir ao atribuírem cabeçalhos os descrições em um registro bibliográfico, para indicar o conteúdo de um trabalho em um catálogo de biblioteca, índice ou base de dados bibliográfica [...]. Por exemplo, se o cabeçalho permitido atribuído para trabalhos sobre cães for "Cães", então todos os itens sobre cães serão atribuídos ao cabeçalho "Cães", incluindo um trabalho intitulado "Tudo sobre Caninos". Uma referência cruzada no cabeçalho "Cães" será feita a partir do termo "Caninos" para assegurar que todos aquele que procurar por informações sobre cães em "Caninos" seja direcionado ao destino correto". (REITZ, 2014, sem paginação, tradução nossa). 


\section{APÊNDICE A - Artigos analisados}

Os artigos analisados tratam de temas relacionados ao futuro da biblioteca universitária, gestão e desafios dos e-books em bibliotecas universitárias, desenvolvimento de coleções, mercado editorial, novas competências para bibliotecários e discussões conceituais de modelos de bibliotecas.

Os artigos trazem em comum que as bibliotecas que passam por mudanças tecnológicas acabam por necessitar de readequação de aspectos organizacionais, como processos de trabalho, estrutura, competências, políticas, etc. Nas pesquisas se observa que as mudanças externas e tecnológicas impulsionam a mudança de conceito de serviço de biblioteca. Outro ponto de convergência entre os artigos é a inexistência de modelos de negócio consolidados para e-books, assim, o próprio mercado editorial precisa se reformular também. Os artigos também retratam o surgimento de novos serviços em ambiente digital nas bibliotecas universitárias, com a necessidade de novos meios de avaliação e acompanhamento. As pesquisas também se aproximam em relação a necessidade de mudar o perfil da liderança: mais dinâmico e presente.

Entre os procedimentos metodológicos utilizados, estudos de caso e revisão de literatura são os mais adotados, seguindo uma abordagem qualitativa. 


\begin{tabular}{|c|c|c|c|c|c|c|}
\hline Artigo & Referência completa & Questão de pesquisa & Método & Abordagem & Resultados & $\begin{array}{l}\text { Trabalhos } \\
\text { futuros }\end{array}$ \\
\hline 2 & $\begin{array}{l}\text { AL-ANSARI, H. A. } \\
\text { Improving organizational } \\
\text { structure for an electronic } \\
\text { environment: a case } \\
\text { analysis of Kuwait } \\
\text { University libraries. Library } \\
\text { Review, v. 48, n. 3, p. } \\
131-139,1999 . \\
\end{array}$ & $\begin{array}{c}\text { Mudanças da estrutura } \\
\text { organizacional com as } \\
\text { novas tecnologias }\end{array}$ & $\begin{array}{c}\text { Qualitativo - estudo } \\
\text { de caso }\end{array}$ & $\begin{array}{c}\text { Análise de } \\
\text { estudo de caso }\end{array}$ & $\begin{array}{l}\text { Estratégias para } \\
\text { conceptualizar } \\
\text { mudanças na } \\
\text { estrutura } \\
\text { organizacional }\end{array}$ & --- \\
\hline 3 & $\begin{array}{l}\text { AMIN, N. M.; GERBIC, P. } \\
\text { Exploring the use of digital } \\
\text { library services in a } \\
\text { blended learning } \\
\text { environment: a malaysian } \\
\text { higher education } \\
\text { perspective. In: } 3 . \text {, } \\
\text { International Conferences } \\
\text { of Education, Research } \\
\text { and Innovation. Madrid, } \\
2010,1782-1792 \text {. }\end{array}$ & $\begin{array}{l}\text { Gestão de serviços em } \\
\text { bibliotecas com serviços } \\
\text { virtuais e presenciais }\end{array}$ & $\begin{array}{c}\text { Qualitativo - estudo } \\
\text { de caso }\end{array}$ & $\begin{array}{c}\text { Análise de } \\
\text { estudo de caso }\end{array}$ & $\begin{array}{c}\text { Demanda por } \\
\text { serviços presenciais } \\
\text { e virtuais }\end{array}$ & Inclusão digital \\
\hline 4 & $\begin{array}{l}\text { BENGHOZI, P. J.; } \\
\text { SALVADOR, E. R\&D in } \\
\text { creative industries: some } \\
\text { lessons from the book } \\
\text { publishing sector. } \\
\text { Tafterjournal, n. 64, } 2013 \text {. }\end{array}$ & $\begin{array}{c}\text { Setor de Pesquisa e } \\
\text { Desenvolvimento na } \\
\text { indústria editorial }\end{array}$ & $\begin{array}{c}\text { Qualitativo - estudo } \\
\text { de caso }\end{array}$ & $\begin{array}{c}\text { Análise de } \\
\text { estudo de caso }\end{array}$ & $\begin{array}{c}\text { Ausência de } \\
\text { investimento em } \\
\text { desenvolvimento } \\
\text { tecnológico ligado } \\
\text { ao desenvolvimento } \\
\text { de modelos de } \\
\text { negócio }\end{array}$ & --- \\
\hline
\end{tabular}




\begin{tabular}{|c|c|c|c|c|c|c|}
\hline 5 & $\begin{array}{l}\text { CASTRO FILHO, C. M. } \\
\text { de. O novo modelo de } \\
\text { biblioteca universitária: } \\
\text { Centro de Recursos para } \\
\text { el Aprendizaje y la } \\
\text { Investigación (CRAI): } \\
\text { serviços, características e } \\
\text { organização. In: XV } \\
\text { Seminário Nacional de } \\
\text { Bibliotecas Universitárias, } \\
\text { 15., 2008, Campinas, p. 2- } \\
\text { 14. }\end{array}$ & $\begin{array}{l}\text { Novo modelo e conceito } \\
\text { de biblioteca } \\
\text { universitária }\end{array}$ & $\begin{array}{l}\text { Qualitativo - estudo } \\
\text { de caso }\end{array}$ & $\begin{array}{c}\text { Conceitual } \\
\text { Análise de } \\
\text { estudo de caso }\end{array}$ & $\begin{array}{c}\text { Mudança de } \\
\text { conceito de } \\
\text { biblioteca implica } \\
\text { em mudança de } \\
\text { gestão }\end{array}$ & $\begin{array}{c}\text { Debate sobre } \\
\text { organização e } \\
\text { gestão de } \\
\text { serviços }\end{array}$ \\
\hline 6 & $\begin{array}{l}\text { CASTRO FILHO, C. M. } \\
\text { de.; VERGUEIRO, W. } \\
\text { Convergências e } \\
\text { divergências do modelo } \\
\text { europeu do Centro de } \\
\text { Recursos para el } \\
\text { Aprendizaje y la } \\
\text { Investigación (CRAI) em } \\
\text { relação às bibliotecas } \\
\text { universitárias brasileiras. } \\
\text { Bibliotecas Universitárias, } \\
\text { v. 1, n. 1, jan./jun. } 2011 .\end{array}$ & $\begin{array}{l}\text { Novo modelo e conceito } \\
\text { de biblioteca } \\
\text { universitária }\end{array}$ & $\begin{array}{l}\text { Qualitativo - estudo } \\
\text { de caso }\end{array}$ & $\begin{array}{c}\text { Conceitual } \\
\text { Análise de } \\
\text { estudo de caso }\end{array}$ & $\begin{array}{l}\text { Mudanças em } \\
\text { estruturas e } \\
\text { culturais para } \\
\text { incorporação de } \\
\text { novos conceitos }\end{array}$ & -- \\
\hline 7 & $\begin{array}{l}\text { CORDÓN-GARCÍA, J. } \\
\text { A.; GÓMEZ-DÍAZ, } \\
\text { R.; ALONSO-ARÉVALO, } \\
\text { J. Libros electrónicos: } \\
\text { oferta comercial y redes } \\
\text { p2p. El profesional de la } \\
\text { información, v. 20, n. 02, } \\
\text { p. 149-158, 2011. }\end{array}$ & $\begin{array}{l}\text { Comércio editorial e } \\
\text { livros eletrônicos }\end{array}$ & $\begin{array}{l}\text { Qualitativo - revisão } \\
\text { de literatura }\end{array}$ & $\begin{array}{l}\text { Casos da } \\
\text { literatura }\end{array}$ & $\begin{array}{c}\text { Plataformas de } \\
\text { venda e distribuição } \\
\text { de ebooks é } \\
\text { escassa, } \\
\text { favorecendo a } \\
\text { procura de redes } \\
\text { p2p pelos leitores. }\end{array}$ & --- \\
\hline 8 & $\begin{array}{l}\text { CUNHA, M. B. da. A } \\
\text { biblioteca universitária na } \\
\text { encruzilhada. }\end{array}$ & $\begin{array}{c}\text { Futuro da biblioteca } \\
\text { universitária }\end{array}$ & $\begin{array}{c}\text { Qualitativo - revisão } \\
\text { de literatura }\end{array}$ & Conceitual & $\begin{array}{c}\text { Mudanças na } \\
\text { biblioteca implica } \\
\text { em questões }\end{array}$ & --- \\
\hline
\end{tabular}




\begin{tabular}{|c|c|c|c|c|c|c|}
\hline & $\begin{array}{l}\text { DataGramaZero, v.11, n. } \\
6,2010 .\end{array}$ & & & & $\begin{array}{l}\text { estruturais e } \\
\text { culturais }\end{array}$ & \\
\hline 10 & $\begin{array}{l}\text { DOMÍNGUEZ AROCA, M. } \\
\text { I. La biblioteca } \\
\text { universitaria ante el nuevo } \\
\text { modelo de aprendizaje: } \\
\text { docentes y bibliotecários, } \\
\text { aprendamos juntos } \\
\text { porque trabajamos juntos. } \\
\text { Revista de Educación a } \\
\text { Distancia, ano 4, número } \\
\text { monográfico 3, p. 1-15, } \\
2005 \text {. }\end{array}$ & $\begin{array}{c}\text { Futuro da biblioteca } \\
\text { universitária }\end{array}$ & $\begin{array}{l}\text { Qualitativo - estudo } \\
\text { de caso }\end{array}$ & $\begin{array}{c}\text { Conceitual } \\
\text { Análise de } \\
\text { estudo de caso }\end{array}$ & $\begin{array}{c}\text { Professores, } \\
\text { universidade e } \\
\text { bibliotecários } \\
\text { alinhados para } \\
\text { implantação de } \\
\text { mudanças }\end{array}$ & --- \\
\hline
\end{tabular}




\begin{tabular}{|c|c|c|c|c|c|c|}
\hline 12 & $\begin{array}{l}\text { DUARTE, A. B. S.; } \\
\text { LOPES, A. de Q.; } \\
\text { ANTUNES, M. L. A.; } \\
\text { FERREIRA, E. G. A.; } \\
\text { PEREIRA, A. L. Livro } \\
\text { eletrônico: o que dizem os } \\
\text { bibliotecários da } \\
\text { Universidade Federal de } \\
\text { Minas Gerais. In: XXV } \\
\text { Congresso Brasileiro de } \\
\text { Biblioteconomia, } \\
\text { Documentação e Ciência } \\
\text { da Informação. 31., } \\
\text { Florianópolis. Anais... } \\
\text { Florianópolis: CBBD, } \\
\text { 2013. }\end{array}$ & $\begin{array}{l}\text { Livro eletrônico e } \\
\text { bibliotecas universitárias }\end{array}$ & $\begin{array}{l}\text { Qualitativo - estudo } \\
\text { de caso }\end{array}$ & $\begin{array}{c}\text { Análise de } \\
\text { estudo de caso }\end{array}$ & $\begin{array}{c}\text { Vantagens e } \\
\text { desvantagens do } \\
\text { livro eletrônico }\end{array}$ & --- \\
\hline 13 & $\begin{array}{l}\text { FINNEMANN, N. O. } \\
\text { Research libraries and the } \\
\text { internet: on the } \\
\text { transformative dynamic } \\
\text { between institutions and } \\
\text { digital. Journal of } \\
\text { Documentation, v. } 70, \mathrm{n} \text {. } \\
2 \text {, p. } 202-220,2014 \text {. }\end{array}$ & $\begin{array}{c}\text { Futuro da biblioteca } \\
\text { universitária }\end{array}$ & $\begin{array}{l}\text { Qualitativo - revisão } \\
\text { de literatura }\end{array}$ & Conceitual & $\begin{array}{l}\text { E-book é uma } \\
\text { mudança disruptiva } \\
\text { e bibliotecas estão } \\
\text { alterando suas } \\
\text { estruturas }\end{array}$ & --- \\
\hline 14 & $\begin{array}{l}\text { FUJITA, M. S. L. Aspectos } \\
\text { evolutivos das bibliotecas } \\
\text { universitárias em } \\
\text { ambiente digital na } \\
\text { perspectiva da rede de } \\
\text { bibliotecas da UNESP. Inf. } \\
\text { \& Soc.: Est., v. 15, n. 2, p. } \\
\text { 97-112, } 2005 .\end{array}$ & $\begin{array}{c}\text { Futuro da biblioteca } \\
\text { universitária }\end{array}$ & $\begin{array}{l}\text { Qualitativo - revisão } \\
\text { de literatura }\end{array}$ & Conceitual & $\begin{array}{l}\text { Co-existência de } \\
\text { serviços presenciais } \\
\text { e virtuais. } \\
\text { Mudanças em } \\
\text { serviços da } \\
\text { biblioteca }\end{array}$ & --- \\
\hline
\end{tabular}




\begin{tabular}{|c|c|c|c|c|c|c|}
\hline 15 & $\begin{array}{l}\text { FURNIVAL, A. C. ; } \\
\text { GRACIOSO, L. de S. M- } \\
\text { libraries e information } \\
\text { commons: novos } \\
\text { espaços, novas } \\
\text { práticas. Geminis, ano 2, } \\
\text { n. 1, p. 86-105, } 2011 .\end{array}$ & $\begin{array}{c}\text { Dispositivos eletrônicos } \\
\text { móveis e bibliotecas }\end{array}$ & $\begin{array}{c}\text { Qualitativo - revisão } \\
\text { de literatura e estudo } \\
\text { de caso }\end{array}$ & $\begin{array}{l}\text { Análise de } \\
\text { casos da } \\
\text { literatura } \\
\text { Conceitual }\end{array}$ & $\begin{array}{l}\text { Invisibilidade dos } \\
\text { serviços da } \\
\text { biblioteca }\end{array}$ & $\begin{array}{c}\text { Novas } \\
\text { possibilidades de } \\
\text { promoção do uso } \\
\text { da informação }\end{array}$ \\
\hline 16 & $\begin{array}{l}\text { FURTADO, J. A. El Papel } \\
\text { y el píxel: de lo impreso a } \\
\text { lo digital: continuidades y } \\
\text { transformaciones. Gijón: } \\
\text { Trea, } 2007 \text {. } \\
\text { (Biblioteconomía y } \\
\text { administración cultural; v. } \\
\text { 163). }\end{array}$ & $\begin{array}{l}\text { Mudanças de suportes } \\
\text { da informação }\end{array}$ & $\begin{array}{l}\text { Qualitativo - revisão } \\
\text { de literatura }\end{array}$ & $\begin{array}{l}\text { Análise de } \\
\text { casos da } \\
\text { literatura } \\
\text { Conceitual }\end{array}$ & $\begin{array}{c}\text { Panorama de } \\
\text { mudanças culturais, } \\
\text { sociais e } \\
\text { tecnológicas do } \\
\text { mercado editorial }\end{array}$ & --- \\
\hline 17 & $\begin{array}{l}\text { GARROD, P. E-books: } \\
\text { are they the interlibrary } \\
\text { lending model of the } \\
\text { future? Interlending \& } \\
\text { Document Supply, v. } 32 \text {, } \\
\text { n. 4, p. } 227-233,2004 .\end{array}$ & $\begin{array}{l}\text { Empréstimo de livros } \\
\text { em contexto digital }\end{array}$ & $\begin{array}{l}\text { Qualitativo - revisão } \\
\text { de literatura }\end{array}$ & $\begin{array}{l}\text { Análise de } \\
\text { casos da } \\
\text { literatura } \\
\text { Conceitual }\end{array}$ & $\begin{array}{l}\text { Novo modelo de } \\
\text { empréstimo entre } \\
\text { bibliotecas }\end{array}$ & --- \\
\hline 18 & $\begin{array}{l}\text { GRAU, I.; ODDONE, N.; } \\
\text { DOURADO, S. E-books, } \\
\text { livros digitais ou livros } \\
\text { eletrônicos? Um estudo } \\
\text { terminológico. In: XIV } \\
\text { Encontro Nacional de } \\
\text { Pesquisa em Ciência da } \\
\text { Informação, 14. , 2013, } \\
\text { Florianópolis. Anais... } \\
\text { Florianópolis: ENANCIB, } \\
\text { 2013. }\end{array}$ & $\begin{array}{l}\text { Terminologia de livro } \\
\text { eletrônico }\end{array}$ & $\begin{array}{l}\text { Qualitativo - estudo } \\
\text { terminológico } \\
\text { (revisão de literatura) }\end{array}$ & Conceitual & $\begin{array}{l}\text { A definição do } \\
\text { conceito de e-book } \\
\text { não é consensual }\end{array}$ & --- \\
\hline 19 & $\begin{array}{l}\text { GUSTIN LACRUZ, M. del } \\
\text { C. Bibliotecas digitales y } \\
\text { sociedad de la }\end{array}$ & $\begin{array}{c}\text { Modelo de bibliotecas } \\
\text { digitais }\end{array}$ & $\begin{array}{l}\text { Qualitativo - revisão } \\
\text { de literatura }\end{array}$ & $\begin{array}{l}\text { Análise de } \\
\text { casos da } \\
\text { literatura }\end{array}$ & $\begin{array}{l}\text { Obstáculos para } \\
\text { implementação de } \\
\text { bibliotecas digitais }\end{array}$ & --- \\
\hline
\end{tabular}




\begin{tabular}{|c|c|c|c|c|c|c|}
\hline & $\begin{array}{l}\text { información. Scire, v. 4, n. } \\
2, \text { p. 47-62, } 1998 .\end{array}$ & & & Conceitual & & \\
\hline 20 & $\begin{array}{l}\text { HAN, N. Managing a 21st- } \\
\text { century library collection. } \\
\text { The Serials Librarian, v. } \\
63, \text { p. } 158-169,2012 \text {. }\end{array}$ & $\begin{array}{l}\text { Gestão de acervos } \\
\text { digitais }\end{array}$ & $\begin{array}{l}\text { Qualitativo - revisão } \\
\text { de literatura }\end{array}$ & $\begin{array}{l}\text { Análise de } \\
\text { casos da } \\
\text { literatura }\end{array}$ & $\begin{array}{l}\text { Obstáculos e } \\
\text { desafios para } \\
\text { gestão }\end{array}$ & --- \\
\hline 21 & $\begin{array}{l}\text { HERTHER, N. K. The e- } \\
\text { book industry today: a } \\
\text { bumpy road becomes an } \\
\text { evolutionary path to } \\
\text { market maturity, The } \\
\text { Electronic Library, v. } 23 \text {, } \\
\text { n. } 01, \text { p. } 45-53,2005 .\end{array}$ & $\begin{array}{l}\text { Comércio editorial e } \\
\text { livros eletrônicos }\end{array}$ & $\begin{array}{l}\text { Qualitativo - revisão } \\
\text { de literatura }\end{array}$ & $\begin{array}{l}\text { Análise de } \\
\text { casos da } \\
\text { literatura }\end{array}$ & $\begin{array}{l}\text { Estado da arte do } \\
\text { mercado editorial e } \\
\text { desafios } \\
\text { relacionados }\end{array}$ & --- \\
\hline 22 & $\begin{array}{l}\text { HUFF-EIBL, R.; VOYLES, } \\
\text { J. F.; BREWER, M. M. } \\
\text { Competency-based hiring, } \\
\text { job description, and } \\
\text { performance goals: the } \\
\text { value of an integrated } \\
\text { system, Journal of Library } \\
\text { Administration, v. } 51 \text {, n. 7- } \\
\text { 8, p. } 673-691,2011 .\end{array}$ & $\begin{array}{l}\text { Novas competências } \\
\text { para bibliotecários }\end{array}$ & $\begin{array}{l}\text { Qualitativo - revisão } \\
\text { de literatura }\end{array}$ & $\begin{array}{l}\text { Análise de } \\
\text { casos da } \\
\text { literatura }\end{array}$ & $\begin{array}{c}\text { Definição de } \\
\text { critérios para } \\
\text { seleção e admissão } \\
\text { de profissionais } \\
\text { com base em novas } \\
\text { competências }\end{array}$ & -- \\
\hline 23 & $\begin{array}{l}\text { HUVILA, T.; HOLMBERG, } \\
\text { K.; KRONQVIST-BERG, } \\
\text { M.; NIVAKOSKI, O.; } \\
\text { WIDÉN, G. What is } \\
\text { librarian 2.0: new } \\
\text { competencies or } \\
\text { interactive relations? A } \\
\text { library professional } \\
\text { viewpoint, Journal of } \\
\text { Librarianship and } \\
\text { Information Science, v. }\end{array}$ & $\begin{array}{l}\text { Novas competências } \\
\text { para bibliotecários }\end{array}$ & $\begin{array}{l}\text { Qualitativo - revisão } \\
\text { de literatura }\end{array}$ & $\begin{array}{l}\text { Análise de } \\
\text { casos da } \\
\text { literatura }\end{array}$ & $\begin{array}{l}\text { Necessidade de } \\
\text { novas } \\
\text { competências, } \\
\text { porém mudanças } \\
\text { estão baseadas em } \\
\text { valores tradicionais } \\
\text { em alguns } \\
\text { profissionais }\end{array}$ & --- \\
\hline
\end{tabular}




\begin{tabular}{|c|c|c|c|c|c|c|}
\hline & 45, n. 3, p.198-205, 2013. & & & & & \\
\hline 24 & $\begin{array}{l}\text { JANTZ, R. C. A } \\
\text { framework for studying } \\
\text { organizational innovation } \\
\text { in research } \\
\text { libraries, College \& } \\
\text { Research Libraries, v. } 73 \text {, } \\
\text { n. } 6, \text { p. } 525-540,2012 a \text {. }\end{array}$ & $\begin{array}{l}\text { Inovação em estrutura } \\
\text { organizacional em } \\
\text { bibliotecas universitárias }\end{array}$ & $\begin{array}{l}\text { Qualitativo - revisão } \\
\text { de literatura }\end{array}$ & $\begin{array}{l}\text { Análise de } \\
\text { casos da } \\
\text { literatura }\end{array}$ & $\begin{array}{l}\text { Obstáculos e } \\
\text { desafios para } \\
\text { inovação em } \\
\text { bibliotecas }\end{array}$ & $\begin{array}{l}\text { Múltiplos fatores } \\
\text { que se } \\
\text { relacionam com } \\
\text { inovação em } \\
\text { bibliotecas }\end{array}$ \\
\hline 25 & $\begin{array}{l}\text { JANTZ, R. C. Innovation } \\
\text { in academic libraries: an } \\
\text { analysis of university } \\
\text { librarians perspectives. } \\
\text { Library \& Information } \\
\text { Science Research, v. 34, } \\
\text { p.3-12, 2012b. }\end{array}$ & $\begin{array}{l}\text { Inovação em estrutura } \\
\text { organizacional em } \\
\text { bibliotecas universitárias }\end{array}$ & $\begin{array}{l}\text { Qualitativo - revisão } \\
\text { de literatura }\end{array}$ & Conceitual & $\begin{array}{c}\text { Análise da inovação } \\
\text { sob a dimensão da } \\
\text { liderança, estrutura } \\
\text { organizacional e } \\
\text { valores } \\
\text { profissionais }\end{array}$ & $\begin{array}{c}\text { Estilos de } \\
\text { liderança, } \\
\text { estruturas } \\
\text { organizacionais }\end{array}$ \\
\hline 26 & $\begin{array}{l}\text { JIANG, Y.; } \\
\text { KATSAMAKAS, E. The } \\
\text { impact of e-book } \\
\text { technology on book } \\
\text { retailing. In: } 43^{\text {rd }} \text { HAWAII } \\
\text { INTERNATIONAL } \\
\text { CONFERENCE ON } \\
\text { SYSTEM SCIENCES, 43., } \\
\text { 2010. Proceedings... s.I.: } \\
\text { IEEE, p. } 1-8 .\end{array}$ & $\begin{array}{c}\text { Mudanças no mercado } \\
\text { editorial }\end{array}$ & $\begin{array}{l}\text { Qualitativo - revisão } \\
\text { de literatura }\end{array}$ & $\begin{array}{l}\text { Análise de } \\
\text { casos da } \\
\text { literatura }\end{array}$ & $\begin{array}{l}\text { Gestão de e-books } \\
\text { no mercado é } \\
\text { alterada }\end{array}$ & --- \\
\hline 27 & $\begin{array}{l}\text { KUMBHAR, R. E-books: } \\
\text { review of research and } \\
\text { writing during } 2010 \text {, The } \\
\text { Electronic Library, v. } 30 \text {, } \\
\text { n. } 6, \text { p. } 777-795,2012 .\end{array}$ & $\begin{array}{l}\text { Questões encontradas } \\
\text { na literatura sobre e- } \\
\text { books }\end{array}$ & $\begin{array}{l}\text { Qualitativo - revisão } \\
\text { de literatura }\end{array}$ & $\begin{array}{c}\text { Estudo } \\
\text { retrospectivo }\end{array}$ & $\begin{array}{l}\text { Crescimento do } \\
\text { mercado de e- } \\
\text { books e surgimento } \\
\text { de novos modelos } \\
\text { de negócio }\end{array}$ & --- \\
\hline 28 & $\begin{array}{l}\text { LANCASTER, F. W. } \\
\text { Ameaça ou oportunidade? } \\
\text { O futuro dos serviços de } \\
\text { biblioteca à luz das }\end{array}$ & $\begin{array}{c}\text { Futuro da biblioteca } \\
\text { universitária }\end{array}$ & $\begin{array}{l}\text { Qualitativo - revisão } \\
\text { de literatura }\end{array}$ & Conceitual & $\begin{array}{l}\text { Novos serviços } \\
\text { com a entrada de } \\
\text { tecnologias da } \\
\text { informação }\end{array}$ & --- \\
\hline
\end{tabular}




\begin{tabular}{|c|c|c|c|c|c|c|}
\hline & $\begin{array}{l}\text { inovações tecnológicas. } \\
\text { Revista Escola } \\
\text { Biblioteconomia UFMG, v. } \\
\text { 23, n.1, p.7-27, } 1994 .\end{array}$ & & & & & \\
\hline 29 & $\begin{array}{l}\text { LUH-WANG, W.; HUI-YI, } \\
\text { H. Study on the strategy } \\
\text { of Taiwan's digital } \\
\text { publishing industry. In: } 3^{\text {rd }} \\
\text { INTERNATIONAL } \\
\text { CONFERENCE } \\
\text { ON INFORMATION } \\
\text { SCIENCES AND } \\
\text { INTERACTION } \\
\text { SCIENCES, 3., 2010. } \\
\text { Proceedings... Chengdu: } \\
\text { IEEE. }\end{array}$ & $\begin{array}{c}\text { Mudanças no mercado } \\
\text { editorial }\end{array}$ & $\begin{array}{l}\text { Qualitativo - revisão } \\
\text { de literatura }\end{array}$ & $\begin{array}{l}\text { Análise de } \\
\text { casos da } \\
\text { literatura }\end{array}$ & $\begin{array}{c}\text { Mercado editorial } \\
\text { deve focar esforços } \\
\text { para o } \\
\text { estabelecimento de } \\
\text { uma cadeia de valor } \\
\text { da indústria digital } \\
\text { de publicação }\end{array}$ & --- \\
\hline 30 & $\begin{array}{l}\text { MACEVICIUTE, E. } \\
\text { Research libraries in a } \\
\text { modern } \\
\text { environment. Journal of } \\
\text { Documentation, v. } 70 \text {, n. } \\
\text { 2, p. 282-302, } 2014 \text {. }\end{array}$ & $\begin{array}{c}\text { Futuro da biblioteca } \\
\text { universitária }\end{array}$ & $\begin{array}{c}\text { Qualitativo - revisão } \\
\text { de literatura }\end{array}$ & Conceitual & $\begin{array}{l}\text { Habilidade de } \\
\text { resiliência de } \\
\text { bibliotecas } \\
\text { universitárias }\end{array}$ & --- \\
\hline 31 & $\begin{array}{l}\text { MACHADO, R. das N.; } \\
\text { NOVAES, M. S. F.; } \\
\text { SANTOS, A. H. dos. } \\
\text { Biblioteca do futuro na } \\
\text { percepção de } \\
\text { profissionais da } \\
\text { informação. } \\
\text { Transinformação, v. 11, n. } \\
\text { 3, p.215-222, 1999. }\end{array}$ & $\begin{array}{c}\text { Futuro da biblioteca } \\
\text { universitária }\end{array}$ & $\begin{array}{l}\text { Qualitativo - estudo } \\
\text { de caso }\end{array}$ & $\begin{array}{c}\text { Análise de } \\
\text { estudo de caso }\end{array}$ & $\begin{array}{l}\text { Necessidade de } \\
\text { mais capacitação }\end{array}$ & --- \\
\hline
\end{tabular}




\begin{tabular}{|c|c|c|c|c|c|c|}
\hline 32 & $\begin{array}{l}\text { MARRA, P. dos S. C. O } \\
\text { papel das bibliotecas } \\
\text { universitárias na } \\
\text { comunicação científica: } \\
\text { um estudo sobre os } \\
\text { repositórios institucionais. } \\
\text { Florianópolis, Encontros } \\
\text { Bibli: revista eletrônica de } \\
\text { biblioteconomia e ciência } \\
\text { da informação, v. 17, n. } \\
\text { esp. } 2, \text { p. } 174-194,2012 \text {. }\end{array}$ & $\begin{array}{c}\text { Repositórios } \\
\text { intitucionais e } \\
\text { bibliotecas universitárias }\end{array}$ & $\begin{array}{l}\text { Qualitativo - revisão } \\
\text { de literatura }\end{array}$ & $\begin{array}{l}\text { Análise de } \\
\text { casos da } \\
\text { literatura }\end{array}$ & $\begin{array}{l}\text { Necessidade de } \\
\text { mais capacitação. } \\
\text { Elaboração de } \\
\text { política institucional } \\
\text { de informação por } \\
\text { uma equipe } \\
\text { multidisciplinar. }\end{array}$ & --- \\
\hline 33 & $\begin{array}{l}\text { MARTINS, R. D. } \\
\text { Perspectiva para uma } \\
\text { biblioteca no futuro: utopia } \\
\text { ou realidade. Informação } \\
\text { e Sociedade: estudos, v. } \\
\text { 12, n.1, p.149-172, } 2002 \text {. } \\
\end{array}$ & $\begin{array}{l}\text { Futuro da biblioteca } \\
\text { universitária }\end{array}$ & $\begin{array}{l}\text { Qualitativo - revisão } \\
\text { de literatura }\end{array}$ & Conceitual & $\begin{array}{l}\text { Novo conceito de } \\
\text { biblioteca é } \\
\text { necessário }\end{array}$ & --- \\
\hline 34 & $\begin{array}{l}\text { MCALLISTER, D.; } \\
\text { MCALLISTER, N.; } \\
\text { VIVIAN, S. The impact of } \\
\text { digital books upon print } \\
\text { publishing. } \\
\text { In: INTERNATIONAL } \\
\text { SYMPOSIUM } \\
\text { ON TECHNOLOGY AND } \\
\text { SOCIETY, 2002. Raleigh, } \\
\text { p. 150-154. } \\
\text { Proceedings... s.l.: IEEE. }\end{array}$ & $\begin{array}{c}\text { Mudanças no mercado } \\
\text { editorial }\end{array}$ & $\begin{array}{l}\text { Qualitativo - revisão } \\
\text { de literatura }\end{array}$ & $\begin{array}{l}\text { Análise de } \\
\text { casos da } \\
\text { literatura }\end{array}$ & $\begin{array}{c}\text { Impactos de } \\
\text { publicações digitais } \\
\text { no mercado } \\
\text { editorial }\end{array}$ & --- \\
\hline 35 & $\begin{array}{l}\text { MICHALAK, S. C. This } \\
\text { change everything: } \\
\text { transforming the academic } \\
\text { library, Journal of Library } \\
\text { Administration, v. } 52 \text {, } \\
2012 \text {, p. } 411-423 \text {. }\end{array}$ & $\begin{array}{l}\text { Futuro da biblioteca } \\
\text { universitária }\end{array}$ & $\begin{array}{l}\text { Qualitativo - revisão } \\
\text { de literatura }\end{array}$ & Conceitual & $\begin{array}{l}\text { Futuro da biblioteca } \\
\text { está ligado a } \\
\text { colaboração, } \\
\text { liderança e } \\
\text { tecnologia difundida }\end{array}$ & --- \\
\hline
\end{tabular}




\begin{tabular}{|c|c|c|c|c|c|c|}
\hline 36 & $\begin{array}{l}\text { MUNDT, M.; MEDAILLE, } \\
\text { A. New medias, new } \\
\text { challenges: the library and } \\
\text { multimedia literacy in } \\
\text { higher education. The } \\
\text { International Journal of } \\
\text { Technology, Knowledge } \\
\text { and Society, v. 7, n. 2, } \\
\text { p.49-60, 2011. }\end{array}$ & $\begin{array}{c}\text { Desenvolvimento de } \\
\text { competências e } \\
\text { contribuição da } \\
\text { biblioteca na vida } \\
\text { acadêmica dos usuários }\end{array}$ & $\begin{array}{l}\text { Qualitativo - estudo } \\
\text { de caso }\end{array}$ & $\begin{array}{c}\text { Análise de } \\
\text { estudo de caso }\end{array}$ & $\begin{array}{l}\text { Necessidade de } \\
\text { profissionais } \\
\text { qualificados e maior } \\
\text { relacionamento } \\
\text { entre biblioteca e } \\
\text { docentes }\end{array}$ & --- \\
\hline 37 & $\begin{array}{l}\text { OLIVEIRA, D. A. O papel } \\
\text { do editor gaúcho frente à } \\
\text { produção e } \\
\text { comercialização dos livros } \\
\text { digitais. In: } 3^{\circ} \\
\text { CONGRESSO } \\
\text { INTERNACIONAL CBL } \\
\text { DO LIVRO DIGITAL, 3., } \\
\text { 2012, São Paulo. Anais... } \\
\text { Disponível em: }< \\
\text { http://www.congressodoliv } \\
\text { rodigital.com.br/blog/wp- } \\
\text { content/TC-danusa- } \\
\text { almeida-de-oliveira- } \\
\text { 100412235559.doc>. } \\
\text { Acesso em: } 01 \text { fev. } 2013 .\end{array}$ & $\begin{array}{l}\text { Setor editorial e livros } \\
\text { eletrônicos }\end{array}$ & $\begin{array}{l}\text { Qualitativo - estudo } \\
\text { de caso }\end{array}$ & $\begin{array}{c}\text { Análise de } \\
\text { estudo de caso }\end{array}$ & $\begin{array}{c}\text { União entre editoras } \\
\text { para nova } \\
\text { configuração do } \\
\text { mercado editorial } \\
\text { de livros digitais }\end{array}$ & --- \\
\hline 38 & $\begin{array}{l}\text { RAO, S. S. Electronic } \\
\text { books: a review and } \\
\text { evaluation, Library Hi } \\
\text { Tech, v. } 21, \text { n. } 01,2003 \text {, } \\
\text { p. } 85-93 .\end{array}$ & $\begin{array}{c}\text { Questões encontradas } \\
\text { na literatura sobre e- } \\
\text { books: }\end{array}$ & $\begin{array}{c}\text { Qualitativo - revisão } \\
\text { de literatura }\end{array}$ & $\begin{array}{c}\text { Estudo } \\
\text { retrospectivo }\end{array}$ & $\begin{array}{c}\text { O sucesso da } \\
\text { adoção de e-books } \\
\text { dependerá dos } \\
\text { modelos de negócio } \\
\text { desenvolvidos pelo } \\
\text { mercado editorial }\end{array}$ & --- \\
\hline 39 & $\begin{array}{l}\text { SHAW, W. The } \\
\text { forgotten e-book market. } \\
\text { Information Today, v. } 27 \text {, } \\
\text { n. } 6,2010 \text {. }\end{array}$ & $\begin{array}{c}\text { Mudanças no mercado } \\
\text { editorial }\end{array}$ & $\begin{array}{l}\text { Qualitativo - revisão } \\
\text { de literatura }\end{array}$ & $\begin{array}{l}\text { Análise de } \\
\text { casos da } \\
\text { literatura }\end{array}$ & $\begin{array}{l}\text { Existência de um } \\
\text { mercado de e- } \\
\text { books antigo }\end{array}$ & --- \\
\hline
\end{tabular}




\begin{tabular}{|c|c|c|c|c|c|c|}
\hline 40 & $\begin{array}{l}\text { TONKERY, D. Publishing } \\
\text { industry sales: good news } \\
\text { for publishers, not so } \\
\text { much for } \\
\text { libraries?. Searcher, v. } 19 \text {, } \\
\text { n. 09, } 2011 \text {. }\end{array}$ & $\begin{array}{c}\text { Mudanças no mercado } \\
\text { editorial }\end{array}$ & $\begin{array}{c}\text { Qualitativo - revisão } \\
\text { de literatura }\end{array}$ & $\begin{array}{l}\text { Análise de } \\
\text { casos da } \\
\text { literatura }\end{array}$ & $\begin{array}{l}\text { Mercado editorial } \\
\text { ainda está } \\
\text { aprendendo a lidar } \\
\text { com desafios e } \\
\text { novidades } \\
\text { tecnológicas }\end{array}$ & --- \\
\hline 41 & $\begin{array}{l}\text { TRAVICA, B. } \\
\text { Organizational aspects of } \\
\text { the virtual library: a survey } \\
\text { of academic libraries. } \\
\text { Library \& Information } \\
\text { Science Research, v. } 21 \text {, } \\
\text { n. } 2 \text {, p. } 173-203,1999 \text {. }\end{array}$ & $\begin{array}{c}\text { Mudanças da estrutura } \\
\text { organizacional com as } \\
\text { novas tecnologias }\end{array}$ & Qualitativo - survey & $\begin{array}{l}\text { Análise dos } \\
\text { dados do } \\
\text { survey }\end{array}$ & $\begin{array}{l}\text { Biblioteca digital é } \\
\text { considerada por } \\
\text { vários profissionais } \\
\text { apenas como uma } \\
\text { tecnologia e não um } \\
\text { modelo de } \\
\text { biblioteca } \\
\end{array}$ & --- \\
\hline 42 & $\begin{array}{l}\text { VASILEIOU, M.; } \\
\text { HARTLEY, R.; ROWLEY, } \\
\text { J. Choosing e-book: a } \\
\text { perspective from } \\
\text { academic libraries. Online } \\
\text { Information Review, v. 36, } \\
\text { n. 1, p. 21-39, 2012b. }\end{array}$ & $\begin{array}{l}\text { Critérios e processos } \\
\text { utilizados em bibliotecas } \\
\text { acadêmicas para } \\
\text { escolher e-books }\end{array}$ & $\begin{array}{c}\text { Qualitativo - estudo } \\
\text { de caso }\end{array}$ & $\begin{array}{c}\text { Análise de } \\
\text { estudo de caso }\end{array}$ & $\begin{array}{l}\text { Modelo de negócio, } \\
\text { preço, licença, } \\
\text { plataforma, } \\
\text { interface, cobertura } \\
\text { temática são } \\
\text { adotados como } \\
\text { critério de seleção } \\
\text { de e-books }\end{array}$ & --- \\
\hline 43 & $\begin{array}{l}\text { VASILEIOU, M.; } \\
\text { ROWLEY, J. } \\
\text { HARTLEY,R. The e-book } \\
\text { management framework: } \\
\text { the management of e- } \\
\text { books in academic } \\
\text { libraries and its } \\
\text { challenges. Library \& } \\
\text { Information Science, v. } \\
34, \text { p. } 282-291,2012 a . \\
\end{array}$ & $\begin{array}{l}\text { Gestão de e-books em } \\
\text { bibliotecas universitárias }\end{array}$ & $\begin{array}{c}\text { Qualitativo - revisão } \\
\text { de literatura e estudo } \\
\text { de caso }\end{array}$ & $\begin{array}{l}\text { Análise de } \\
\text { casos da } \\
\text { literatura } \\
\text { Conceitual }\end{array}$ & $\begin{array}{l}\text { Modelo de gestão } \\
\text { de e-books com } \\
\text { etapas descritas }\end{array}$ & --- \\
\hline 44 & $\begin{array}{l}\text { VASSILOU, M.; } \\
\text { ROWLEY, J. Progressing } \\
\text { the definition of "e-book". } \\
\text { Library Hi Tech, v. 26, n. }\end{array}$ & $\begin{array}{c}\text { Terminologia de livro } \\
\text { eletrônico }\end{array}$ & $\begin{array}{l}\text { Qualitativo - estudo } \\
\text { terminológico } \\
\text { (revisão de literatura) }\end{array}$ & Conceitual & $\begin{array}{l}\text { Definição de e-book } \\
\text { não é consensual }\end{array}$ & $\begin{array}{l}\text { Mais estudos } \\
\text { sobre uso e } \\
\text { aquisição do e- } \\
\text { book }\end{array}$ \\
\hline
\end{tabular}




\begin{tabular}{|c|c|c|c|c|c|c|}
\hline & 3, p. $355-368,2008$. & & & & & \\
\hline 45 & $\begin{array}{l}\text { VIEIRA, D. V; BAPTISTA, } \\
\text { S. G.; CERVERÓ, A. C. } \\
\text { As competências } \\
\text { profissionais do } \\
\text { bibliotecário } 2.0 \text { no } \\
\text { espaço da biblioteca } \\
\text { universitária: discussão da } \\
\text { prática. Informação e } \\
\text { Sociedade: Estudos, v. } \\
\text { 23, n. 2, p. 45-58, } 2013 \text {. }\end{array}$ & $\begin{array}{l}\text { Novas competências } \\
\text { para bibliotecários }\end{array}$ & $\begin{array}{l}\text { Qualitativo - revisão } \\
\text { de literatura }\end{array}$ & $\begin{array}{l}\text { Análise de } \\
\text { casos da } \\
\text { literatura }\end{array}$ & $\begin{array}{l}\text { Importância da } \\
\text { mediação da } \\
\text { informação como } \\
\text { competência }\end{array}$ & $\begin{array}{l}\text { Mais estudos } \\
\text { sobre usuários }\end{array}$ \\
\hline 46 & $\begin{array}{l}\text { WALTERS, W. H. E- } \\
\text { books in academic } \\
\text { libraries: challenges for } \\
\text { acquisition and collection } \\
\text { management. Portal: } \\
\text { Libraries and the } \\
\text { Academy, v. } 13, \text { n. } 2, \text { p. } \\
\text { 187-211, } 2013 \text {. }\end{array}$ & $\begin{array}{l}\text { Gestão de e-books em } \\
\text { bibliotecas universitárias }\end{array}$ & $\begin{array}{l}\text { Qualitativo - estudo } \\
\text { de caso }\end{array}$ & $\begin{array}{l}\text { Análise de } \\
\text { casos da } \\
\text { literatura }\end{array}$ & $\begin{array}{c}\text { Dificuldades para } \\
\text { desenvolvimento de } \\
\text { coleções de e- } \\
\text { books }\end{array}$ & --- \\
\hline 47 & $\begin{array}{l}\text { WILKINS, V. Managing e- } \\
\text { books at the University of } \\
\text { Derby: a case study. } \\
\text { Program, v. } 41, \text { n. } 3 \text {, p. } \\
\text { 238-251, 2007. }\end{array}$ & $\begin{array}{l}\text { Gestão de e-books em } \\
\text { bibliotecas universitárias }\end{array}$ & $\begin{array}{c}\text { Qualitativo - revisão } \\
\text { de literatura e estudo } \\
\text { de caso }\end{array}$ & $\begin{array}{l}\text { Análise de } \\
\text { casos da } \\
\text { literatura }\end{array}$ & $\begin{array}{l}\text { Diversidade de } \\
\text { serviços e } \\
\text { abordagens pelos } \\
\text { fornecedores de e- } \\
\text { books trazem } \\
\text { desafios de gestão. }\end{array}$ & --- \\
\hline
\end{tabular}

